\title{
THE REGIONAL AQUIFER SYSTEM UNDERLYING THE NORTHERN GREAT PLAINS IN PARTS OF MONTANA, NORTH DAKOTA, SOUTH DAKOTA, AND WYOMING-SUMMARY
}

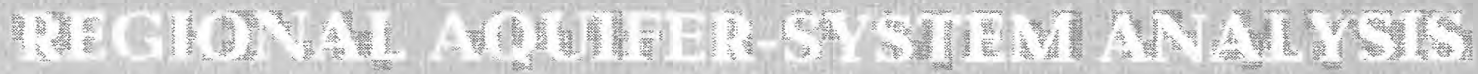

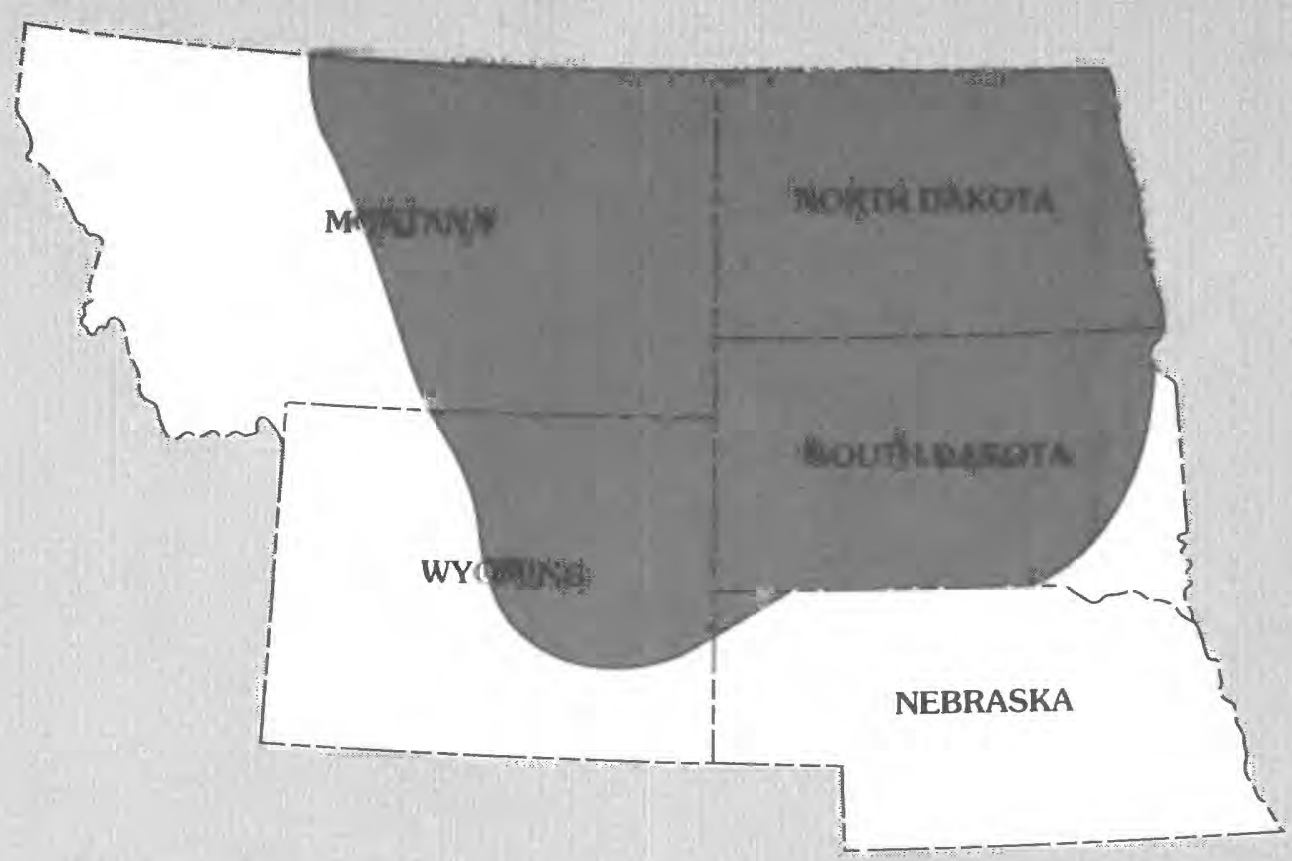




\section{The Regional Aquifer System Underlying}

the Northern Great Plains in Parts of Montana, North Dakota, South Dakota, and Wyoming-Summary

By JOE S. DOWNEY and GEORGE A. DINWIDDIE

R E G I O N A L A Q U I F E R - S Y S T E M A N A L Y S I S

U.S. GEOLOGICAL SURVEY PROFESSIONAL PAPER 1402-A

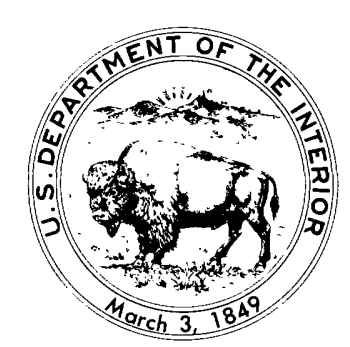




\section{DEPARTMENT OF THE INTERIOR}

DONALD PAUL HODEL, Secretary

\section{U.S. GEOLOGICAL SURVEY}

Dallas L. Peck, Director

Library of Congress Cataloging-in-Publication Data

Downey, Joe S.

The regional aquifer system underlying the northern Great Plains in parts of Montana, North Dakota, South Dakota, and Wyoming-summary.

(Regional aquifer-system analysis) (Geological Survey professional paper ; 1402-A)

Bibliography: p.

Supt. of Docs. no.: I 19.16:1402-A

1. Aquifers-Great Plains. 2. Aquifers-Montana. 3. Aquifers-North Dakota. 4. Aquifers-South Dakota.

5. Aquifers-Wyoming.

I. Dinwiddie, George A., 1933- . $\quad$ II. Title. III. Series. IV. Series: Geological Survey professional paper ; 1402-A. GB1199.3.G74D69 1986 $551.49^{\prime} 0978$

$85-600320$

For sale by the Books and Open-File Reports Section,

U.S. Geological Survey, Federal Center, Box 25425, Denver, CO 80225 


\section{FOREWORD}

\section{THE REGIONAL AQUIFER-SYSTEM ANALYSIS PROGRAM}

The Regional Aquifer-System Analysis (RASA) Program was started in 1978 following a congressional mandate to develop quantitative appraisals of the major ground-water systems of the United States. The RASA Program represents a systematic effort to study a number of the Nation's most important aquifer systems, which in aggregate underlie much of the country and which represent an important component of the Nation's total water supply. In general, the boundaries of these studies are identified by the hydrologic extent of each system and accordingly transcend the political subdivisions to which investigations have often arbitrarily been limited in the past. The broad objective for each study is to assemble geologic, hydrologic, and geochemical information, to analyze and develop an understanding of the system, and to develop predictive capabilities that will contribute to the effective management of the system. The use of computer simulation is an important element of the RASA studies, both to develop an understanding of the natural, undisturbed hydrologic system and the changes brought about in it by human activities, and to provide a means of predicting the regional effects of future pumping or other stresses.

The final interpretive results of the RASA Program are presented in a series of U.S. Geological Survey Professional Papers that describe the geology, hydrology, and geochemistry of each regional aquifer system. Each study within the RASA Program is assigned a single Professional Paper number, and where the volume of interpretive material warrants, separate topical chapters that consider the principal elements of the investigation may be

published. The series of RASA interpretive reports begins with Professional Paper 1400 and thereafter will continue in numerical sequence as the interpretive products of subsequent studies become available.

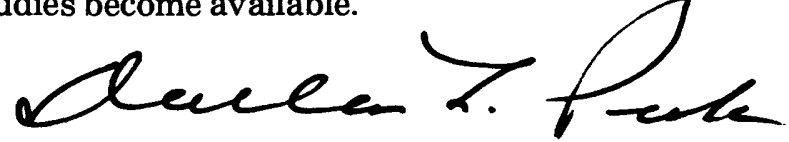

Dallas L. Peck Director 


\section{U.S. GEOLOGICAL SURVEY PROFESSIONAL PAPERS ISSUED AS A PART OF THE NORTHERN GREAT PLAINS REGIONAL AQUIFER-SYSTEM ANALYSIS PROGRAM}

1402-A The regional aquifer system underlying the northern Great Plains in parts of Montana, North Dakota, South Dakota, and Wyoming-Summary: By Joe S. Downey and George A. Dinwiddie.

1402-B Geologic framework of the ground-water system in Jurassic and Cretaceous rocks in the northern Great Plains in parts of Montana, North Dakota, South Dakota, and Wyoming: By Lawrence O. Anna.

1402-C Geochemical evolution of ground water in two sandstone aquifer systems in the northern Great Plains in parts of Montana and Wyoming: By Thomas Henderson.

1402-D Freshwater heads and ground-water temperatures in aquifers of the northern Great Plains in parts of Montana, North Dakota, South Dakota, and Wyoming: By David H. Lobmeyer.

1402-E Geohydrology of bedrock aquifers in the northern Great Plains in parts of Montana, North Dakota, South Dakota, and Wyoming: By Joe S. Downey.

1402-F Geochemistry of ground water in aquifers and confining units of the northern Great Plains in parts of Montana, North Dakota, South Dakota, and Wyoming: By J.F. Busby, B.A. Kimball, J.S. Downey, and K.D. Peter. 


\section{CONTENTS}

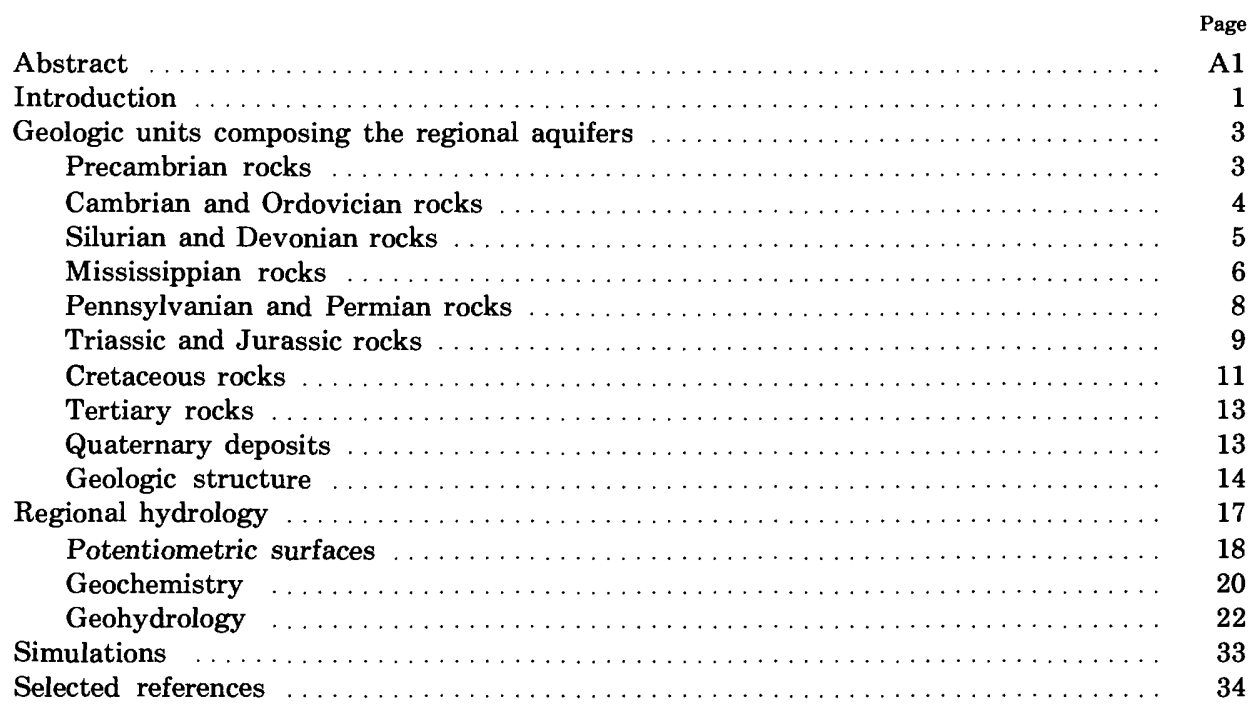

\section{ILLUSTRATIONS}

[Plates are in pocket]

Plate 1. Generalized correlation chart of Paleozoic rocks of the northern Great Plains in parts of Montana, North Dakota, South Dakota, and Wyoming.

2. Generalized correlation chart of Jurassic, Cretaceous (Mesozoic), and Tertiary rocks of the northern Great Plains in parts of Montana, North Dakota, South Dakota, and Wyoming.

3. Maps showing hydrologic flow system in Paleozoic and Mesozoic aquifers in the northern Great Plains in parts of Montana, North Dakota, South Dakota, and Wyoming, and in adjacent parts of Canada.

1-3. Maps showing:

1. Location of study area, Fort Union coal region, and sites of principal subsurface control ........

2. Present-day structural and physiographic features of the northern Great Plains and vicinity ......

3. Approximate thickness of rocks of Cambrian and Ordovician age $\ldots \ldots \ldots \ldots \ldots \ldots \ldots \ldots \ldots \ldots$ 4. Generalized geohydrologic section showing relationship of aquifers and confining layers from a ground-water recharge area in Montana to a discharge area in North Dakota $\ldots \ldots \ldots \ldots \ldots \ldots \ldots \ldots \ldots \ldots \ldots \ldots \ldots \ldots \ldots \ldots \ldots \ldots$

Page

A2

4

5 
FiguRES 5-9. Maps showing approximate thickness of rocks of:

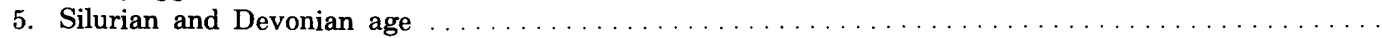

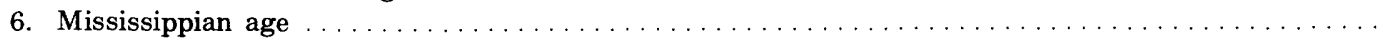

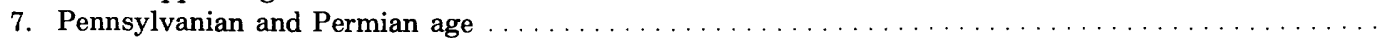

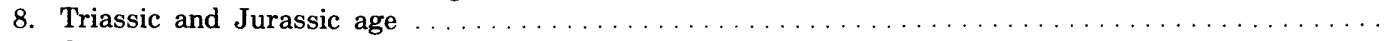

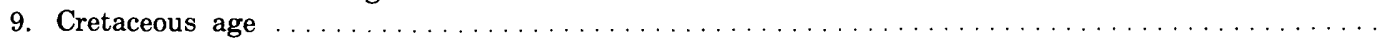

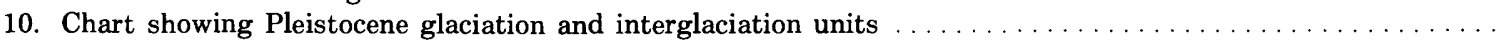
11-14. Maps showing:

11. Extent of Laurentide (Wisconsin) ice in the northern Great Plains and vicinity

12. Major Paleozoic structural features in the northern Great Plains and vicinity

13. Subsurface paleolineament zones of Jurassic and Cretaceous age in the northern Great Plains and vicinity

14. Lineament patterns, delineated using Landsat imagery, in the northern Great Plains and vicinity ...

15. Photograph showing solution features in marine limestone developed in subtropical conditions similar to those postulated to exist during Late Mississippian time

16. Map showing predevelopment potentiometric surface of the Cambrian-Ordovician aquifer system (before 1950)

17. Map showing potentiometric surface derived from measurements of head in locally permeable parts of the Devonian rocks

18-21. Maps showing predevelopment potentiometric surface of the:

18. Mississippian aquifer system (including the Madison Limestone) (before 1950) $\ldots \ldots \ldots \ldots \ldots$

19. Pennsylvanian aquifer system (before 1950)

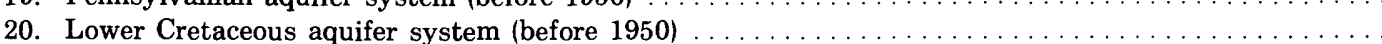

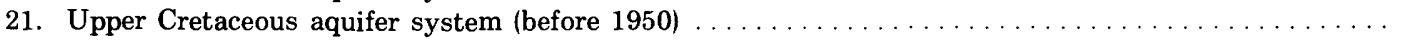

22-25. Maps showing water temperatures in the:

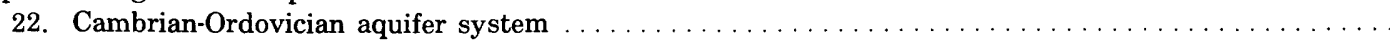

23. Mississippian aquifer system, including the Madison Limestone $\ldots \ldots \ldots \ldots \ldots \ldots \ldots \ldots \ldots \ldots$

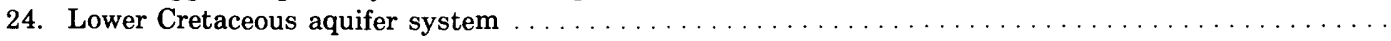

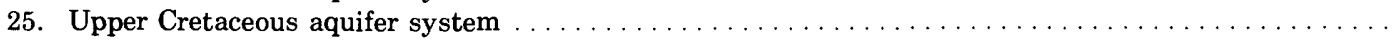

26-32. Maps showing concentration of dissolved solids in water from the:

26. Cambrian-Ordovician aquifer system

27. Silurian and Devonian rocks (a major confining system or unit overlying the Cambrian-Ordovician aquifer

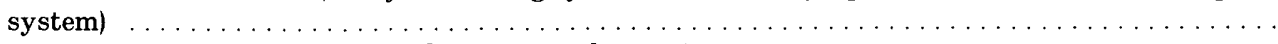

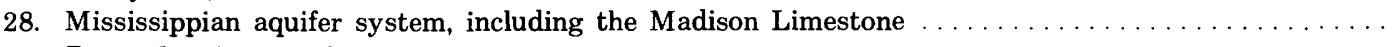

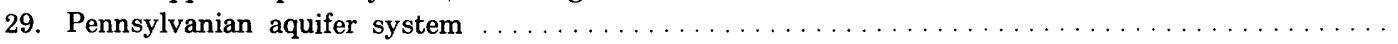

30. Triassic and Jurassic rocks (a major confining system or unit overlying the Pennsylvanian aquifer system)

31. Lower Cretaceous aquifer system

32. Upper Cretaceous aquifer system

33-38. Maps showing hydrochemical facies of water in the:

33. Cambrian-Ordovician aquifer system

34. Silurian and Devonian rocks (a major confining system or unit overlying the Cambrian-Ordovician aquifer system)

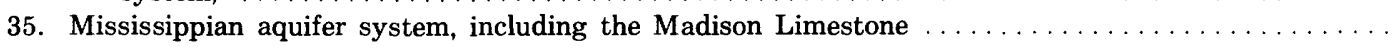

36. Pennsylvanian aquifer system

37. Lower Cretaceous aquifer system

38. Upper Cretaceous aquifer system

39-41. Generalized geohydrologic sections showing:

39. Simulated rates of ground-water recharge, flow, leakage, and discharge from a ground-water recharge area in Montana to a discharge area in North Dakota

40. Ground-water discharge from the aquifer systems consisting of rocks of Paleozoic age to the aquifer systems

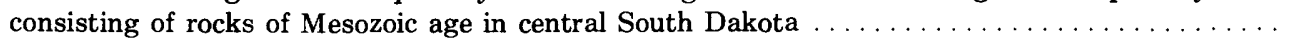

41. Ground-water movement in the Cambrian-Ordovician aquifer system in northeastern North Dakota .

42. Map showing calculated rates of ground-water movement in the Cambrian-Ordovician aquifer system study area and adjacent parts of Canada

43. Map showing calculated rates of ground-water movement in the Mississippian aquifer system (including the Madison

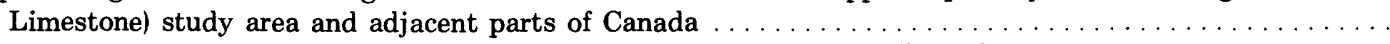

44. Generalized geohydrologic section showing locations of brine in the Williston basin $\ldots \ldots \ldots \ldots \ldots$

45-49. Maps showing calculated drawdown in aquifer systems after 5.9 years of hypothetical pumping at specific rates and assumed storage coefficients:

45. Pennsylvanian aquifer system pumping from the Mississippian aquifer system $\ldots \ldots \ldots \ldots \ldots \ldots$

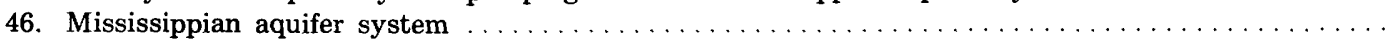

47. Cambrian-Ordovician aquifer system pumping from the Mississippian aquifer system $\ldots \ldots \ldots \ldots$

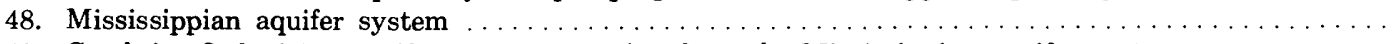

49. Cambrian-Ordovician aquifer system pumping from the Mississippian aquifer system $\ldots \ldots \ldots \ldots$ 


\section{CONVERSION FACTORS}

Inch-pound units in this report may be converted to units in the International System of Units (SI) using the following conversion factors:

\begin{tabular}{lcl}
\hline \multicolumn{1}{c}{ Multiply inch-pound units } & By & \multicolumn{1}{c}{ To obtain SI units } \\
\hline acre & $4,047$. & square meter \\
acre-foot (acre-ft) & $1,233.0$ & cubic meter \\
cubic foot $\left(\mathrm{ft}^{3}\right)$ & 0.02832 & cubic meter \\
cubic foot per second $\left(\mathrm{ft}^{3} / \mathrm{s}\right)$ & 0.02832 & cubic meter per second \\
cubic mile $\left(\mathrm{mi}^{3}\right)$ & 4.827 & cubic kilometer \\
foot (ft) & 0.3048 & meter \\
& 30.48 & centimeter \\
foot per second (ft/s) & 0.3048 & meter per second \\
foot squared per day $\left(\mathrm{ft}^{2} / \mathrm{d}\right)$ & 0.0929 & meter squared per day \\
inch (in.) & 2.540 & centimeter \\
& 25.40 & millimeter \\
mile (mi) & 1.609 & kilometer \\
million gallons per day $(\mathrm{Mgal} / \mathrm{d})$ & 0.003785 & cubic meter per day \\
pound per square inch $\left(\mathrm{lb} / \mathrm{in}^{2}\right)$ & 0.07037 & kilogram per square centimeter \\
square foot $\left(\mathrm{ft}^{2}\right)$ & 929.0 & square centimeter \\
square mile $\left(\mathrm{mi}^{2}\right)$ & 2.59001 & square kilometer \\
\hline \multicolumn{1}{c}{ Multiply $\mathrm{SI}$ units } & $\mathrm{By}$ & To obtain inch-pound units \\
\hline degree Celsius $\left({ }^{\circ} \mathrm{C}\right)$ & $\circ \mathrm{F}=9 / 5\left({ }^{\circ} \mathrm{C}\right)+32$ & degree Fahrenheit \\
\hline
\end{tabular}





\title{
THE REGIONAL AQUIFER SYSTEM UNDERLYING THE NORTHERN GREAT PLAINS IN PARTS OF MONTANA, NORTH DAKOTA, SOUTH DAKOTA, AND WYOMING-SUMMARY
}

\author{
By JOe S. DOWNEY and GeORGE A. DinWIdde
}

\section{ABSTRACT}

The Northern Great Plains Regional Aquifer-System Analysis is the first of a series of planned nationwide regional geohydrologic studies. This summary is principally a graphic presentation of the major results of four basic facets of investigation designed to provide the best possible understanding of a large (about 300,000 square miles) and extremely complex ground-water flow system. The reader is encouraged to refer to subsequent volumes in this series for the details of treatment of components and of results of the study.

The geologic framework within which the ground-water flow system operates has been defined. The study area basically consists of highland areas of sediment sources and basin areas of sediment deposition. The geologic investigation principally involved definition of the types of sediment (any rocks), the areal extent and thickness of sediment (any rocks), and the mechanisms that controlled deposition of the sediments.

The spatial distribution of hydraulic pressure has been portrayed as potentiometric surfaces mapped for several aquifers. The implied ground-water flow system is one of recharge in and near the highland areas in the western and southwestern part of the study area and one of generally eastward and northeastward flow of ground water toward areas of discharge in Canada, North Dakota, and South Dakota.

The distribution of chemical quality of the ground water has been defined with available data, and the mechanisms controlling changes in chemical quality have been interpreted. The chemistry of water from aquifers of Paleozoic through Mesozoic age is controlled by a variety of geochemical mechanisms, with dissolution of evaporites and mixing of water being dominant. Dedolomitization is a significant mechanism, and sulfate reduction and cation exchange are probably active mechanisms as well.

The entire system of ground-water flow with all of its controlling factors has been defined as a conceptual model and has been simulated with a mathematical model. Five major aquifers have been defined and simulated, and the digital model has been used to interpret areas and rates of recharge, areas and rates of discharge, areas and rates of leakage, and rates and directions of flow. The model has been further used to simulate several hypothetical pumping alternatives to determine the cause-and-effect relationship between pumping, drawdown, and assumed conditions.

\section{INTRODUGTION}

The northern Great Plains region of North America is, except for the Black Hills, a fairly flat, gently rolling surface underlain mostly by sandstone and shale (pls. 1, 2). The land surface is interrupted at places by several hundred feet of topographic relief where streams have dissected relatively soft rock. The northern Great Plains study area, shown in figure 1 , covers about $300,000 \mathrm{mi}^{2}$ in the Great Plains and Central Lowland physiographic provinces. The study area is bounded on the west by the central and northern Rocky Mountains, on the east by the Red River of the North, on the south by the central High Plains, and on the north by the United States-Canadian border. The rocks consist of sediments that were eroded from present and ancestral mountains to the west, and from the Black Hills, and were deposited in the subsiding Williston and Powder River basins and surrounding areas to thicknesses of more than $15,000 \mathrm{ft}$. Subsequently, several hundred feet of these sedimentary rocks were eroded, leaving remnants of resistant rock. The principal aquifers, which generally are areally extensive, crop out along the flanks of two major basins (Powder River and Williston basins) and along other major structural features. Significant aquifers also occur in unconsolidated glacial drift in North Dakota and South Dakota.

Developing energy resources, generating power, developing industry, increasing irrigation, and satisfying the greater requirements for domestic and municipal water in the northern Great Plains area will depend in large part on the development of supplies of ground water. Streamflow historically has satisfied many of the water needs; however, surface water is fully appropriated in much of the area and is not always a dependable supply because flows are extremely variable. Long-term, large-scale water needs will require development of productive aquifers, some of which have been little used heretofore. Large, sustained yields of ground water cannot be produced efficiently, and sound management plans cannot be formulated without a knowledge of the physical and hydrologic characteristics of the groundwater system and its response to withdrawals. Ground water needs to be developed in a logical manner and 


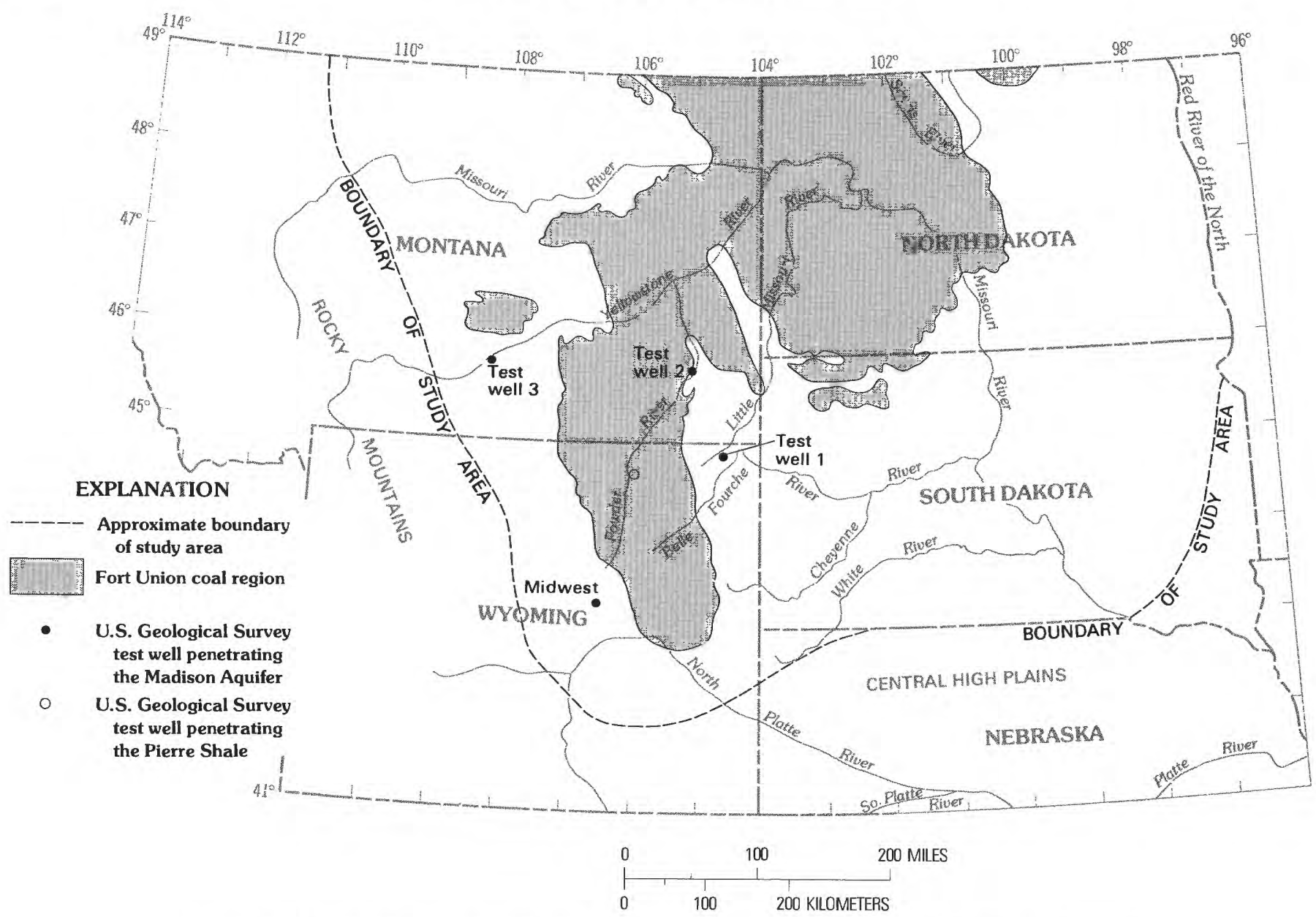

FIgURE 1.-Location of study area, Fort Union coal region, and sites of principal subsurface control.

needs to be used with regard for the consequences of extraction and consumption.

Comprehensive study of the geology and hydrology of the northern Great Plains area by the U.S. Geological Survey (USGS) began in 1975 with the Madison Limestone study. The Madison study was conceived and begun in response to a generally recognized need for knowledge about potential supplemental sources of large quantities of water to support possible large-scale development of coal reserves. A major part of the United States' coal reserves is in the Fort Union coal region of the northern Great Plains (fig. 1). Major development of the coal, which can include onsite steam power generation, gasification, liquefaction, and slurry pipeline transport of coal, would place a major demand on the area's limited water resources. Large quantities of water would be needed; estimates exceed 200,000 acre-ft per year. Preliminary studies by the USGS and State agencies in Montana, South Dakota, and Wyoming have indicated that the Madison Limestone and associated rock units might provide a significant percentage of the total water requirements for the coal development.

The Northern Great Plains Regional Aquifer-System Analysis (RASA) is the first study in the USGS RASA Program, the general purpose of which is to fully understand the Nation's ground-water resources. Studies of ground-water resources have been on a local scale, responsive to local, immediate needs. These studies usually have been restricted within political boundaries. However, for defining total ground-water resources and for planning the most effective development and use of these resources, hydrologic studies are needed on a regional scale. Thus, the concept of regional aquifer-system analyses as described in the Foreword was developed.

The northern Great Plains regional aquifer-system study was a logical extension and culmination of the Madison Limestone study. The study was designed to complete the definition of the total ground-water flow 
system above the rocks of Precambrian age and was conducted with a four-component approach to the problem:

1. Geology-The geologic framework within which ground water flows and the mechanisms that controlled sediment deposition were defined.

2. Hydrology-The spatial distribution of hydraulic pressure, which is the ultimate driving force of ground-water movement, was defined.

3. Geochemistry-Chemical quality of the ground water and the mechanisms controlling changes in chemical quality were interpreted.

4. Geohydrology-The entire system of ground-water flow with all of its controlling factors was defined as a conceptual model; then a mathematical simulation model was developed with which unknown areas and unknown values could be defined in the terms and within the limits of the model.

This report presents summary results from both the Madison Limestone project and the northern Great Plains regional aquifer-system study. Because of the nature of topics, some discussions may be in greater detail than others. However, for comprehensive information on a specific subject, the reader should refer to the subsequent reports in this professional paper series listed in the front of this report. For further information, the reader also can consult the selected references for this report.

\section{GEOLOGIC UNITS COMPOSING THE REGIONAL AQUIFERS}

The present-day geologic structure of the northern Great Plains (fig. 2) is related directly to the geologic history of the Cordilleran platform, which is a part of the stable interior of the North American continent. During geologic time, many structural features developed that affected the deposition of the various sedimentary units. Most of these structural features are present today and are important in determining the present hydrologic regime existing in all the aquifer systems underlying the northern Great Plains (Weimer and others, 1982).

During Paleozoic time, the study area (fig. 1) was part of the Cordilleran platform, a broad flat area that was bordered on the west by Cordilleran miogeosyncline. Most of the detrital sediments in the synclinal trough came from the Antler orogenic belt, which probably was an island-arc system to the west that underwent intermittent tectonism during Paleozoic time. The Transcontinental arch, southwest of the study area, was low lying and contributed minor quantities of sediment that were spread thinly across the platform. In general, the
Cordilleran platform was a shallow-water depositional shelf that received predominantly carbonate and evaporite sediments during most of Paleozoic time.

The Black Hills uplift (fig. 2) was not a regionally significant tectonic element until Late Cretaceous time (Agnew and Tychsen, 1965) and had little influence on Paleozoic sedimentation. During Mississippian time, the study area generally was covered by a shallow warm sea probably less than a few feet deep (Sando, 1976b). Shoals and reefs were common but continually changed and shifted because of the effects of geologic forces in time and space. Many of these shallow areas had small reefs and associated oolite-and crinoid-bank shoals and lagoons. The lagoons were evaporating basins in which evaporites precipitated and became incorporated into the lime-rich bottom sediments. Gypsum often could precipitate in a lagoonal environment that frequently received influxes of sea water, whereas evaporation seldom would proceed to the point of halite precipitation. Areas in the Williston basin and the Central Montana trough with restricted sea-water circulation or higher evaporation rates are evidenced by accumulations of bedded evaporites.

During Cretaceous time, the study area was covered by a north-trending sea that extended from the Gulf of Mexico to the Arctic Ocean. Source areas to the west provided clastic sediments that were deposited in the Cretaceous sea. The Precambrian shield area, northeast of the study area, was a positive Cretaceous feature and provided sediments that were deposited in the eastern part of the Cretaceous sea. The Sioux uplift in eastern South Dakota provided sediment for two major delta systems that prograde into southeastern Montana.

\section{PRECAMBRIAN ROCKS}

Crystalline rocks of Precambrian age form the basement in the northern Great Plains region. Depth to the Precambrian basement varies greatly; basement crops out in the eastern and western parts of the study area (fig. 3) but lies greater than $15,000 \mathrm{ft}$ below land surface at the center of the Williston basin. Precambrian rocks also are found in the central cores of the many mountain ranges located in the western part of the study area.

On a regional basis, little is known about the wateryielding properties of the Precambrian rocks. Available data indicate that they contain only small quantities of water in joints and fractures. These rocks therefore are generally not considered to be water yielding; however, along major fractures, Precambrian rocks can produce water that is available from leakage from the overlying sedimentary sequence. Precambrian rocks in 


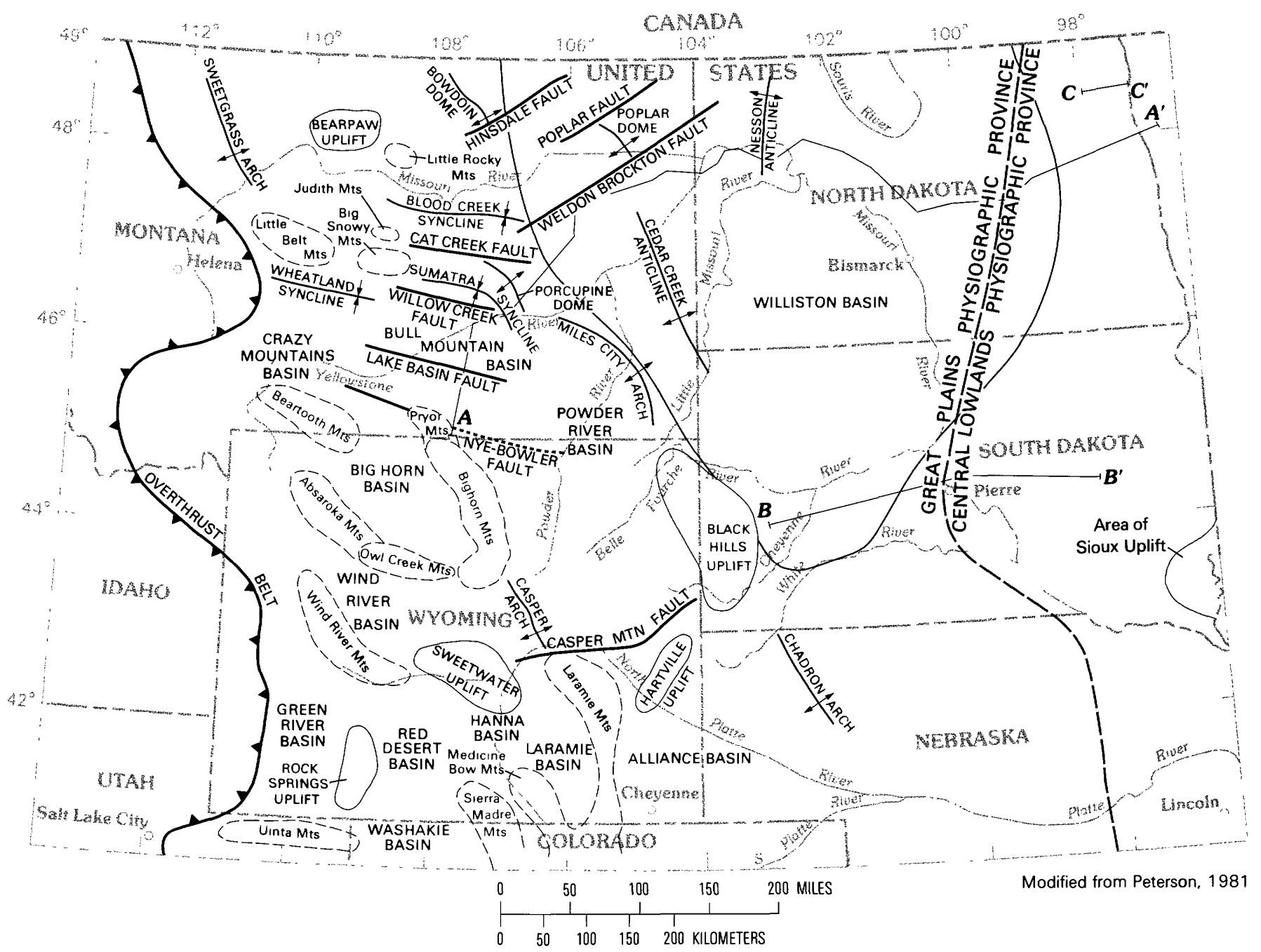

FIGURE 2.-Present-day structural and physiographic features of the northern Great Plains and vicinity (includes lines of sections $A-A$; $B-B^{\prime}$, and $C-C^{\prime}$.

the study area represent the lower boundary of the hydrologic system. In the eastern part of the study area where Precambrian rocks crop out, the rocks act as noflow boundaries to the hydrologic system.

\section{CAMBRIAN AND ORDOVICIAN ROCKS}

Rocks of Cambrian and Ordovician age (pl. 1; fig. 3) in the northern Great Plains consist of marine sandstone, shale, limestone, and dolomite that represent the shoreward facies of a transgressive sea which occupied the area during Cambrian and Ordovician time (Peterson, 1981). Several formations of Cambrian and Ordovician age, such as the Deadwood, the Winnipeg, and the Red River Formations, are aquifers (fig. 4); however, their great depth has prevented their use as a major source of water, and few hydrologic data concerning these aquifers are available on a regional scale. Most of the data are from tests performed in connection with the development of oil and gas wells.

Ordovician rocks are major petroleum reservoirs in the Williston basin, and many exploratory wells penetrate these rocks. Ordovician rocks are not present in southeastern Wyoming, western Montana, and a small portion of southwestern South Dakota because of nondeposition, or erosion, during Devonian and Early Mississippian time. Thickness increases eastward and northward from central Montana and northeastern Wyoming to more than $1,000 \mathrm{ft}$ in the central part of the Williston basin.

The Winnipeg Formation is stratigraphically equivalent to the St. Peter Sandstone of the midwestern United States. In the western part of the study area 


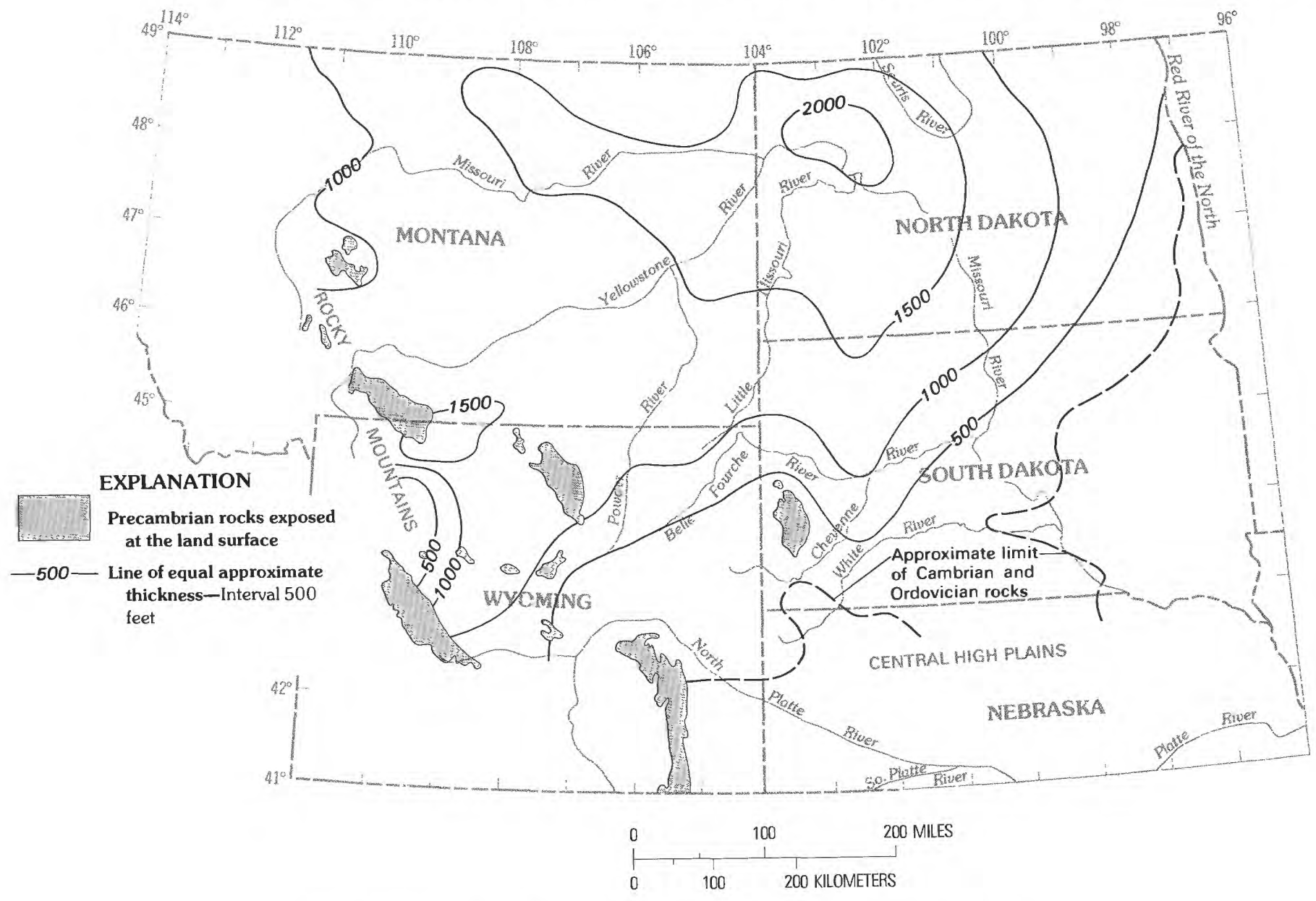

Figure 3.-Approximate thickness of rocks of Cambrian and Ordovician age.

where it is not deeply buried, the Winnipeg Formation consists of a clean, well-sorted, medium-grained, porous sandstone (Peterson, 1978). Where it is deeply buried, the unit has little porosity and permeability because of silica cementation and related compaction. In the eastern discharge area of the hydrologic system (pl. 3), the Winnipeg Formation consists of a sequence of shale, sandstone, and shaly limestone ranging in thickness from 20 to about $140 \mathrm{ft}$ (Armstrong, 1980). The sandstone units consist of very fine to fine rounded quartz grains with interbedded siltstone and shale.

The Red River Formation (pl. 1), a carbonate sequence that overlies the Winnipeg Formation, extends outward past the borders of the Williston basin. The Red River Formation is more than $700 \mathrm{ft}$ thick in the central part of the Williston basin and was truncated by Devonian erosion in the western part of the study area along a line extending between the central Black Hills and the southern Bighorn Mountains (Peterson, 1981).
The Stony Mountain Formation, which conformably overlies the Red River, is composed of carbonate, shaly carbonate, and anhydrite beds and lithologically is similar to the overlying Interlake Formation of latest Ordovician and Silurian age. Both the Red River and Stony Mountain Formations were truncated by Devonian erosion around the periphery of the Williston basin. The Stony Mountain erosional edge is closer to the basin center than that of the underlying Red River Formation.

\section{SILURIAN AND DEVONIAN ROCKS}

Rocks of Silurian and Devonian age (pl. 1; fig. 5) overlie the formations of Ordovician age in most of the study area. Silurian and Devonian units consist mainly of shaly carbonate rocks, shale, and evaporite deposits, including Devonian halite (fig. 5), near the center of the Williston basin where the units have a total thickness greater than $3,000 \mathrm{ft}$. The halite units of Devonian age 


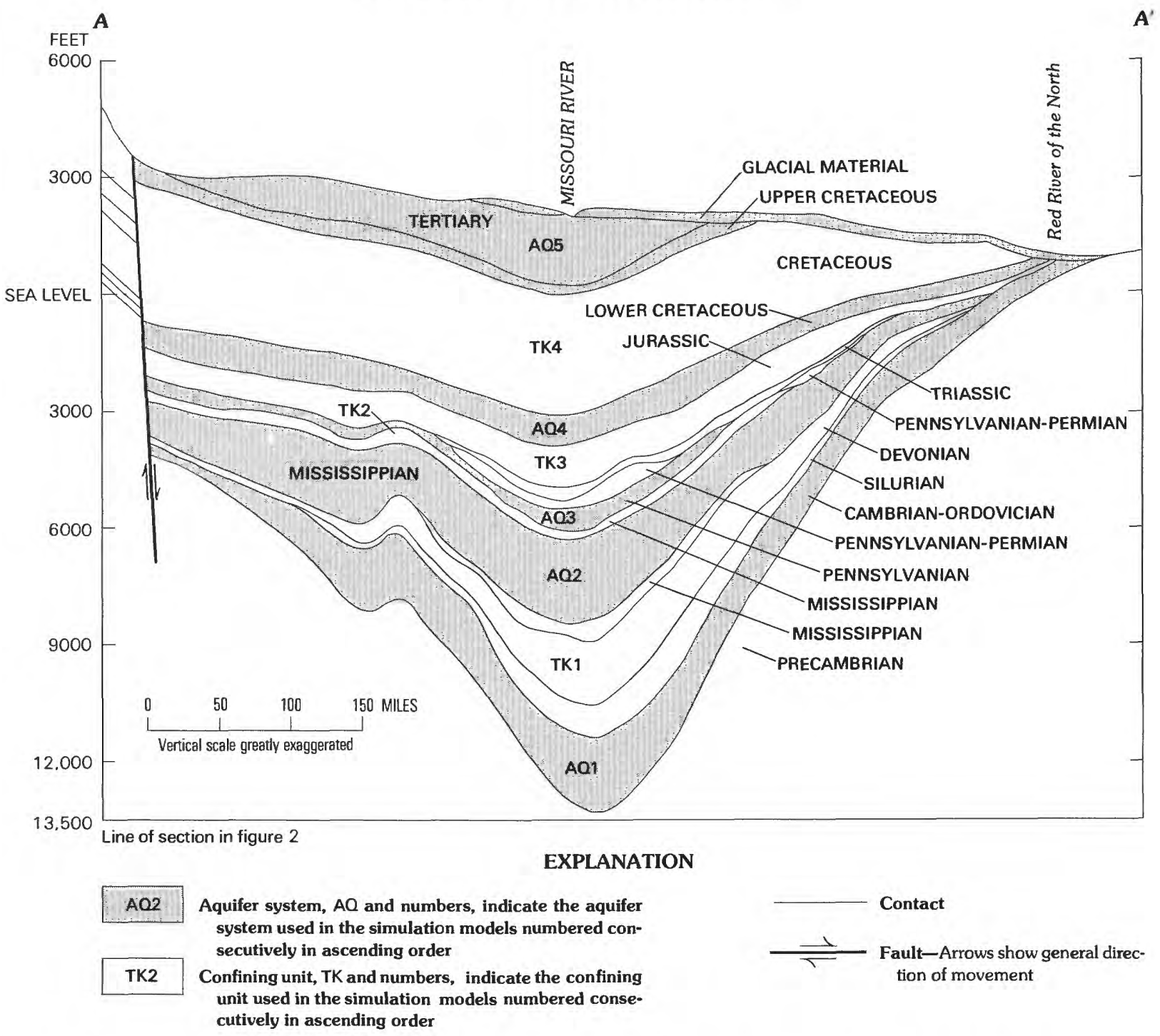

FIGURE 4.-Generalized geohydrologic section showing relationship of aquifers and confining layers from a ground-water recharge area in Montana to a discharge area in North Dakota.

extend northward into Canada for about $1,200 \mathrm{mi}$, underlying the Provinces of Alberta, Saskatchewan, and Manitoba and reaching into the Northwest Territories. The Prairie salt (informal subsurface usage), one of the principal halite units of Devonian age in the study area, contains many structural lows along its margin and locally within it. These structural lows have been attributed to postdepositional solution of halite, allowing collapse of the overlying formations into the void created by dissolution (DeMille and others, 1964; Grossman, 1968). Because of the fine-grained lithology and the presence of evaporite deposits in the Silurian and Devonian units, these formations act as confining beds for the underlying Cambrian-Ordovician aquifer (fig. 4).

\section{MISSISSIPPIAN ROCKS}

Rocks of Mississippian age (pl. 1; fig. 6) overlie the Devonian formations. The Mississippian rocks have been subdivided into several formations and one stratigraphic group.

The lowermost Mississippian unit is the upper part of the Bakken Formation, which overlies the Devonian Three Forks Formation. The Bakken Formation consists of more than $100 \mathrm{ft}$ of black, organic shale and siltstone and appears to be an excellent hydrologic confining bed where it is present in the study area. This confining bed was delineated into the Devonian-Silurian confining unit shown in figure 4. The Bakken Formation is considered to be a source bed for much of the 


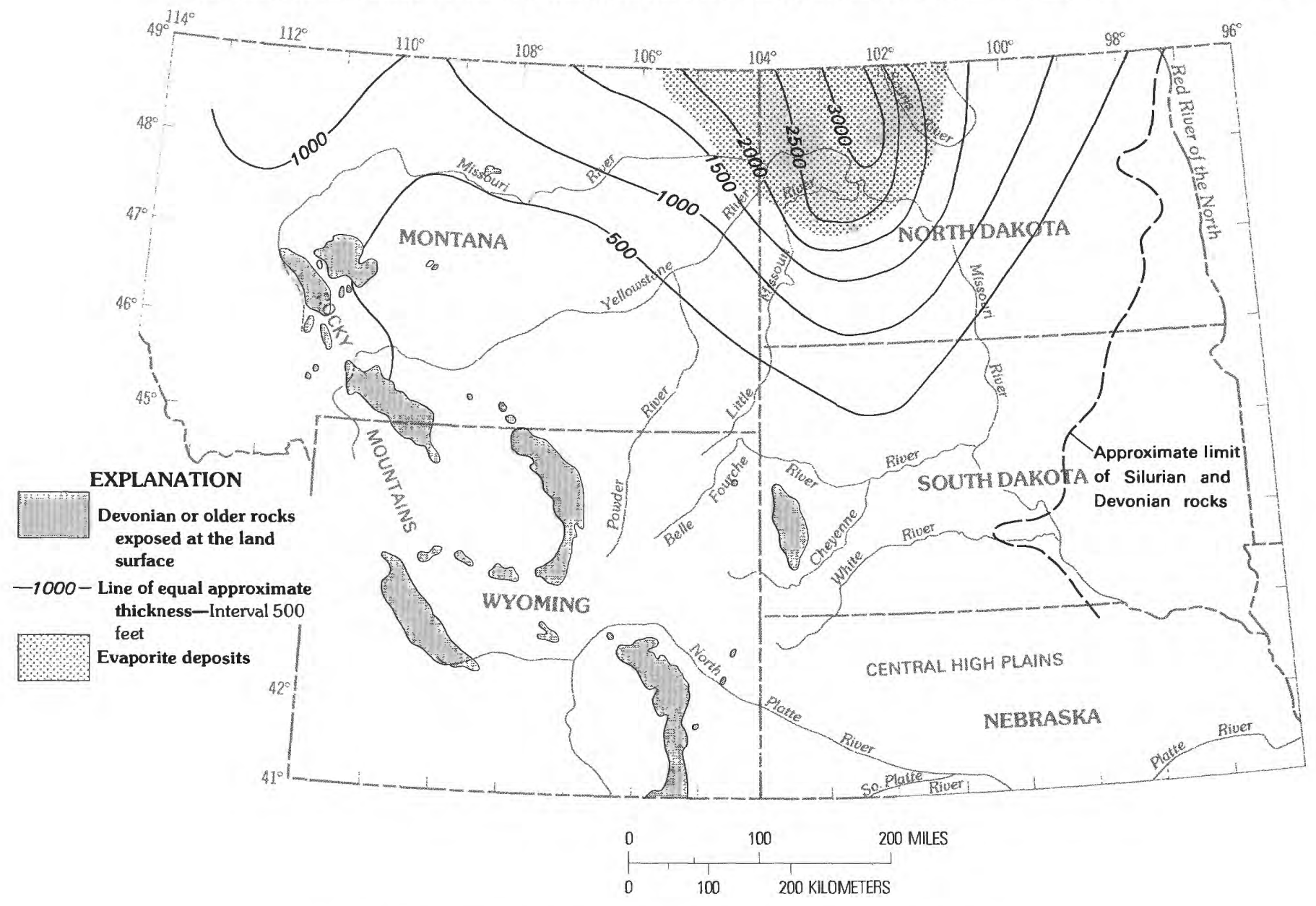

FIGURE 5.-Approximate thickness of rocks of Silurian and Devonian age.

petroleum found in overlying formations. Overlying the Bakken Formation is a sequence of Mississippian rocks, mainly limestone and dolomite, that are termed the Madison Group (where divided) or Madison Limestone, a major aquifer system in the study area (fig. 4).

The Madison Limestone in the study area consists of a sequence of marine carbonate rocks and evaporite deposits distributed mainly in a warm shallow-water environment similar to that which exists today near the coast of southern Florida and the Yucatan Peninsula in Mexico. Depositional environments grade both laterally and vertically from shallow-marine carbonate and evaporite facies to deep-water clay and siltstone facies. The Madison Group, from oldest to youngest, consists of the Lodgepole Limestone, the Mission Canyon Limestone, the Charles Formation, or their stratigraphic equivalents in other parts of the study area (pl. 1).

The Lodgepole Limestone is predominantly a cyclic carbonate sequence largely consisting of fossiliferous to micritic dolomite and limestone units that are argillaceous and thin bedded in most of the study area (Smith, 1972). The unit ranges from 0 to more than $900 \mathrm{ft}$ in thickness, with an average thickness of about $300 \mathrm{ft}$ in the study area. The Lodgepole Limestone overlies the Bakken Formation in the Williston basin.

The Mission Canyon Limestone consists of coarsely crystalline limestone at its base, grading upward to finer crystalline limestone and evaporite deposits near the top (Peterson, 1981). The formation contains one evaporite cycle and shares a second evaporite cycle with the lower part of the Charles Formation. Bedded evaporite units are absent in most of Wyoming and South Dakota, but evaporite deposits occur in southeastern Montana and northwestern North Dakota and gradually thicken from central Montana toward their maximum thicknesses in the Williston basin. The Mission Canyon Limestone ranges from 0 to more than $650 \mathrm{ft}$ in thickness, with an average thickness of about $300 \mathrm{ft}$ in the study area.

The Charles Formation, the uppermost unit of the Madison Group, is a marine evaporite sequence 


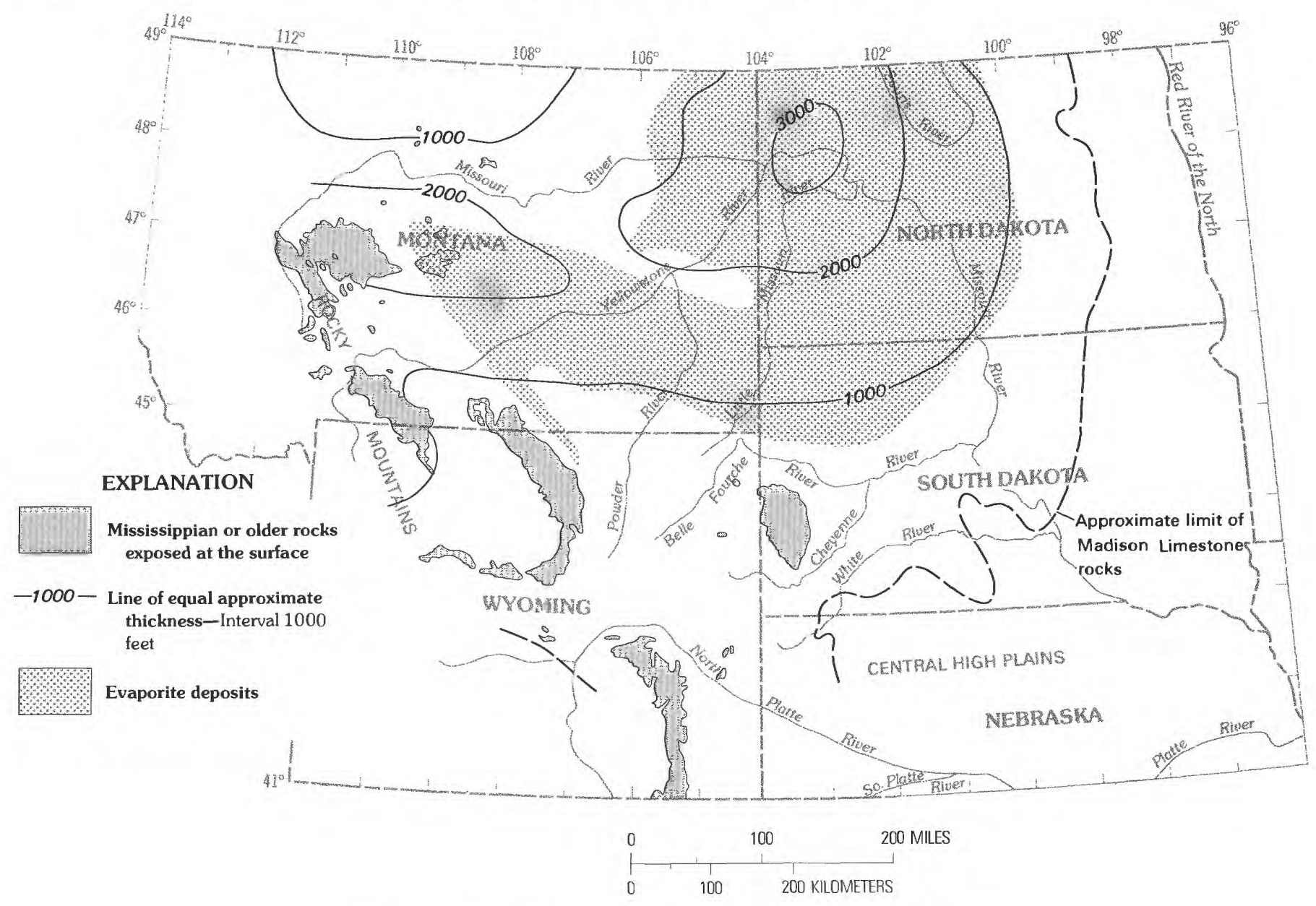

Figure 6.-Approximate thickness of rocks of Mississippian age.

consisting of anhydrite and halite with interbedded dolomite, limestone, and argillaceous units. The Charles Formation ranges from 0 to more than $300 \mathrm{ft}$ in thickness, with an average thickness of about $250 \mathrm{ft}$ in the study area. Pre-Jurassic erosion has removed most of the Charles Formation in the western and southern parts of the study area.

Overlying the Charles Formation in parts of Montana, North Dakota, and South Dakota are rocks of Late Mississippian age belonging to the Big Snowy Group. The Big Snowy Group consists mainly of shale and sandstone with minor limestone. Where present, the Charles Formation and rocks of the Big Snowy Group act as a hydrologic confining bed for the underlying aquifers (fig. 4).

\section{PENNSYLVANIAN AND PERMIAN ROCKS}

Rocks of Pennsylvanian age (pl. 1; fig. 7) overlie the Mississippian units in most of the study area and consist of marine sandstone, shale, siltstone, and carbonate rocks. The Pennsylvanian rocks are divided by many formational names; however, most are equivalent units.

The Tyler Formation generally is restricted to the Central Montana trough and the central Williston basin, but the formation grades southward and appears to be equivalent to the lower part of the Amsden Formation in south-central Montana. The Tyler Formation also appears to be equivalent to the lower part of the Minnelusa Formation in northwestern South Dakota and western North Dakota.

Middle Pennsylvanian rocks are represented by the Tensleep Sandstone in southern Montana and northcentral Wyoming and by part of the Minnelusa Formation in the Williston basin in northeastern Wyoming and western South Dakota. Porous sandstone units of Pennsylvanian age are present in the Tensleep Sandstone in central to north-central Wyoming and southcentral Montana, and in the middle part of the Minnelusa Formation in western South Dakota and 


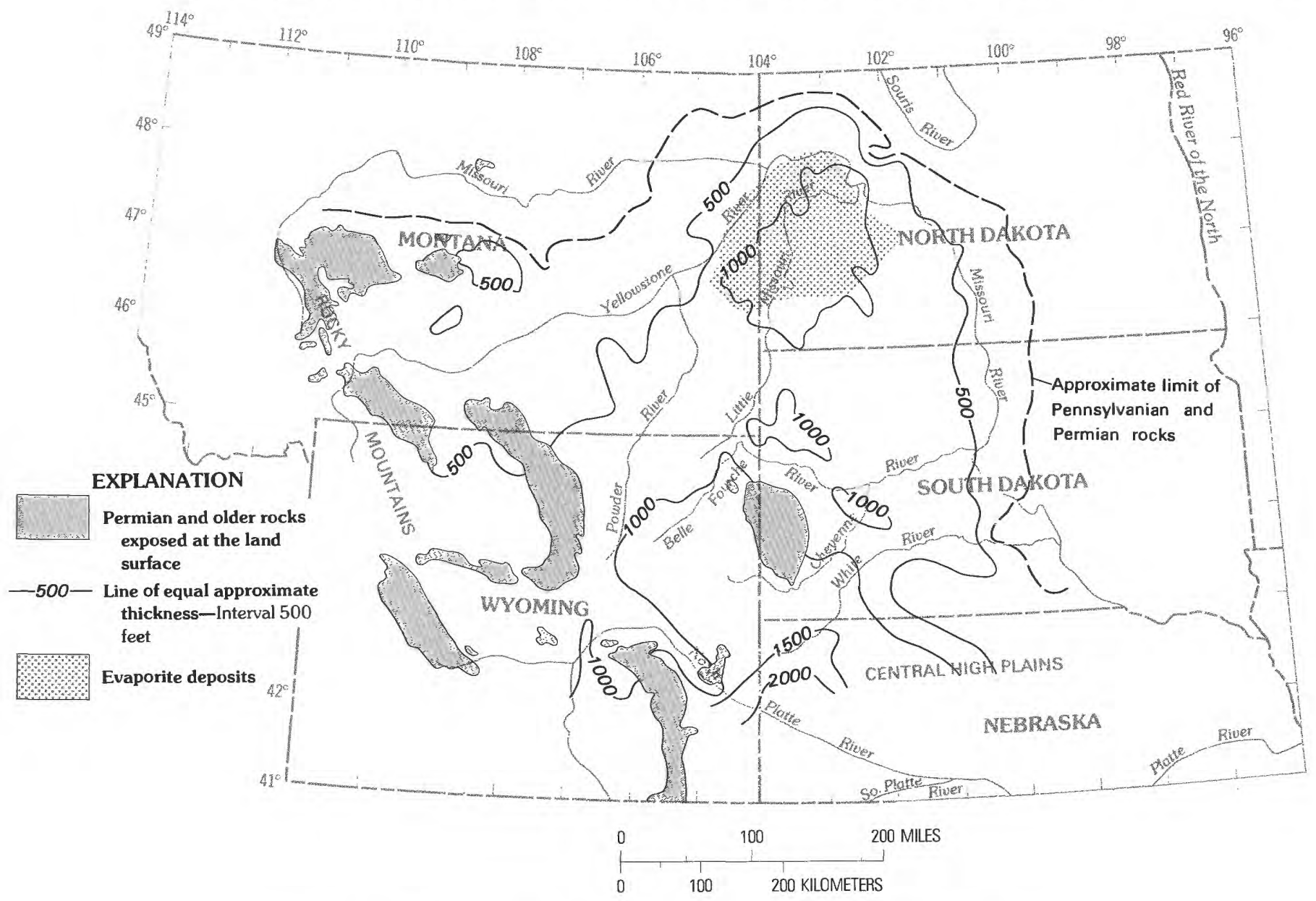

Figure 7.-Approximate thickness of rocks of Pennsylvanian and Permian age.

along the east side of the Williston basin. These rocks have been truncated progressively northward across central Montana by pre-Jurassic erosion.

The upper part of the Minnelusa Formation in the Powder River and Williston basins and in the western part of South Dakota consists of sandstone, shale, and carbonate rocks with interbedded anhydrite of Permian age. The sandstone facies extends northward to include the southeastern part of the Williston basin. The source of the sands in the upper part of the Minnelusa Formation is interpreted to be the reworking of earlier deposited Pennsylvanian sands from paleostructures to the west. Additional source areas were the Sioux uplift and the Canadian Shield on the eastern and northeastern borders of the Williston basin.

Overlying the upper part of the Minnelusa Formation are the Permian Opeche Formation, the Minnekahta Limestone, and the lower part of the Spearfish Formation. The Opeche Formation is interbedded in the central part of the Williston basin with halite beds informally termed the Opeche salt. The Minnekahta
Limestone overlies the Opeche Formation and halite units. Above the Minnekahta Limestone, the Pine salt (informal usage) of the Spearfish Formation contains more than $300 \mathrm{ft}$ of bedded halite, which limits the vertical flow of water through this formation (fig. 4).

\section{TRIASSIC AND JURASSIC ROCKS}

Rocks of Permian age in the study area are overlain by a sequence of red shale, siltstone, and evaporite deposits belonging to the upper part of the Goose Egg and Spearfish Formations of Triassic age (pls. 1, 2; fig. 8). These formations are about 200 to $400 \mathrm{ft}$ thick in the central Williston basin and thicken southwesterly to more than $900 \mathrm{ft}$. in the Powder River basin.

Although shale and siltstone are the principal lithologies of the Triassic units in the study area, sandstone occurs to a limited extent in the eastern part of the Williston basin as elongate northeast-trending sandy belts probably deposited by streams flowing off the 


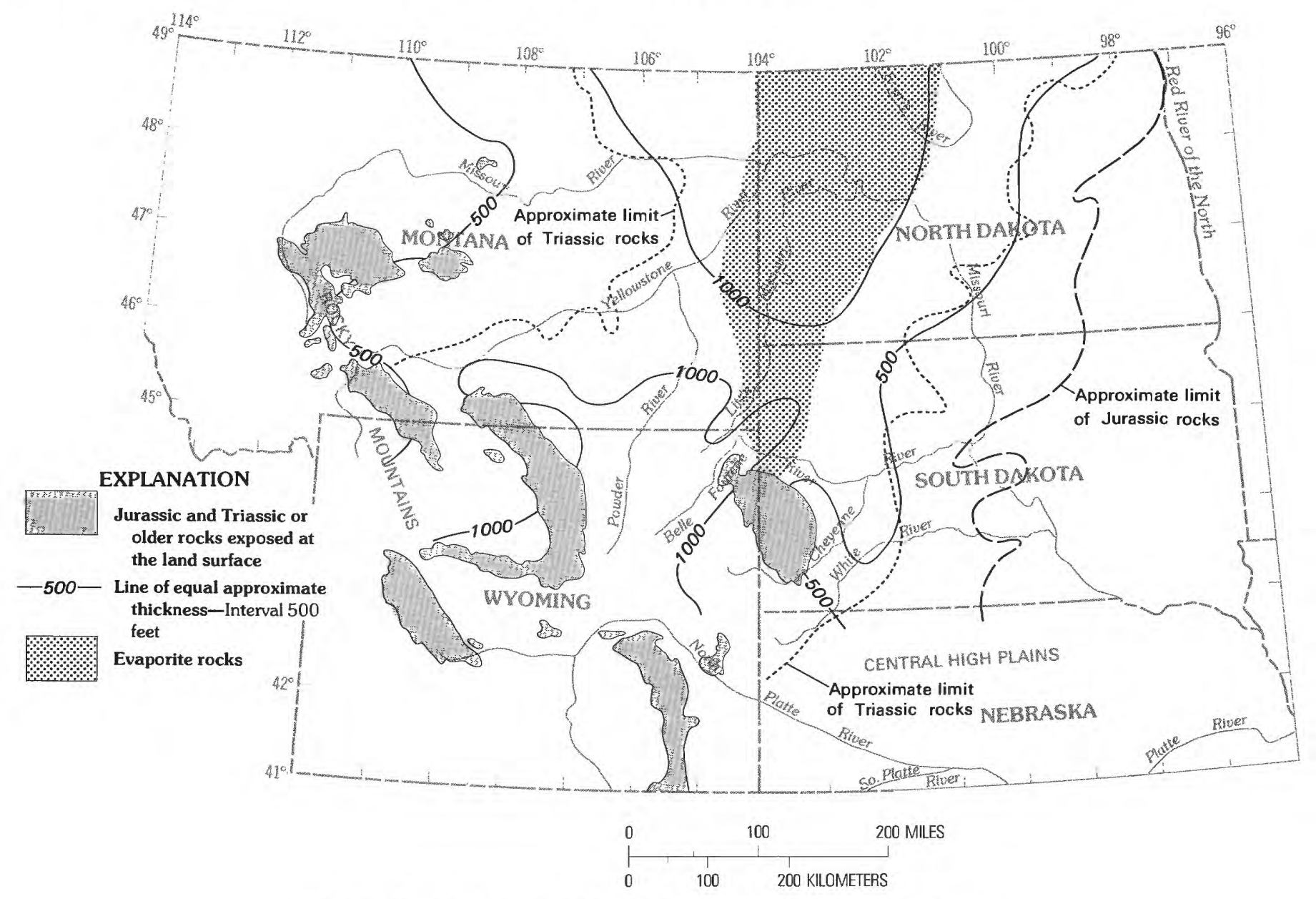

FIGURE 8.-Approximate thickness of rocks of Triassic and Jurassic age.

adjacent Sioux uplift and Canadian Shield source areas to the east. Triassic beds have been truncated by preMiddle Jurassic erosion along the southern and eastern margins of the Alberta shelf and on the east side of the Williston basin. Rocks of Triassic age, along with those of Permian age, are considered to be a confining bed for the flow of ground water from the underlying aquifers to the overlying aquifers of Cretaceous age (fig. 4).

Rocks of Jurassic age overlie formations of Triassic age with a pronounced disconformity. These rocks, consisting of the Nesson, Piper, Rierdon, Swift, and Morrison Formations and their equivalents, are predominantly carbonate rocks, shale, and calcareous shale. The Nesson Formation is subdivided into three informal members: a lower anhydrite, which includes the Dunham salt, occurring in parts of the Williston basin; a middle shale; and an upper carbonate-rock sequence. The Piper Formation also is subdivided into three members: a lower shale and sandstone unit, a middle sandstone, and an upper shale. In north-central
Montana, the Piper Formation thins appreciably and consists chiefly of sandstone. The Rierdon Formation mainly consists of shale, siltstone, and calcareous shale, with small amounts of sandstone along the eastern fringes of the Williston basin.

The Swift Formation was deposited under marine conditions, and in the western part of the study area it consists of sandstone deposited as offshore bars in a shallow sea. In the eastern part, the formation consists mostly of silty shale with coarser sediments occurring in the upper part of the formation. The formation is about $600 \mathrm{ft}$ thick along the northern axis of the Williston basin and thins to near nonexistence in western Montana and in eastern North Dakota and South Dakota. Generally, cementation of the Swift Formation is less than that of adjacent formations, possibly due to a lower primary porosity and to less active diagenetic processes. The Swift Formation is less porous than the sandstones occurring in units of Early Cretaceous age, although in several localities more than $50 \mathrm{ft}$ of sand occurs with greater than 20 percent porosity. 
The Morrison Formation was deposited as a continental deposit of sand, silt, and clay on a plain that emerged after the regression of the sea which existed during deposition of the Swift Formation. The Morrison Formation is about $250 \mathrm{ft}$ thick in south-central Montana and thins eastward to near nonexistence in western North Dakota and South Dakota. A regional unconformity at the base of the Lower Cretaceous units locally truncates both the Morrison Formation and the upper part of the Swift Formation. Total thicknesses of the Jurassic units in the study area range from less than $50 \mathrm{ft}$ along the periphery of the Williston and Powder River basins to more than $1,000 \mathrm{ft}$ north of the deepest part of the Williston basin.

\section{CRETACEOUS ROCKS}

Rocks of Cretaceous age (pl. 2; fig. 9) consist of marine and nonmarine clastic sediments that range in thicknesses from $0 \mathrm{ft}$ in eastern North Dakota and South
Dakota to more than $6,000 \mathrm{ft}$ in northeastern Wyoming. The stratigraphic sequence consists of interbedded shale, siltstone, and sandstone layers with a few beds of limestone or marl. A number of formational names have been applied to the various Cretaceous units in the northern Great Plains region; however, in several instances, these formational names are used only in one State or subregion, as shown on the geologic correlation chart (pl. 2). The Lakota and Fuson Formations of Early Cretaceous age are composed of fluvial sandstone, siltstone, and shale. The Lakota Formation consists mainly of sandstone and occasional conglomerate overlying an erosional surface cut into the underlying Morrison Formation of Jurassic age. Generally, the Lakota Formation is a channel- and valley-fill deposit; however, in the subsurface, it is difficult to distinguish between the valley fill of the Lakota Formation and the valley fill of the overlying Fuson Formation.

The Fuson Formation consists mostly of valley-fill and channel margin deposits of silty shale with occasional sandstone units. Thickness of the Fuson

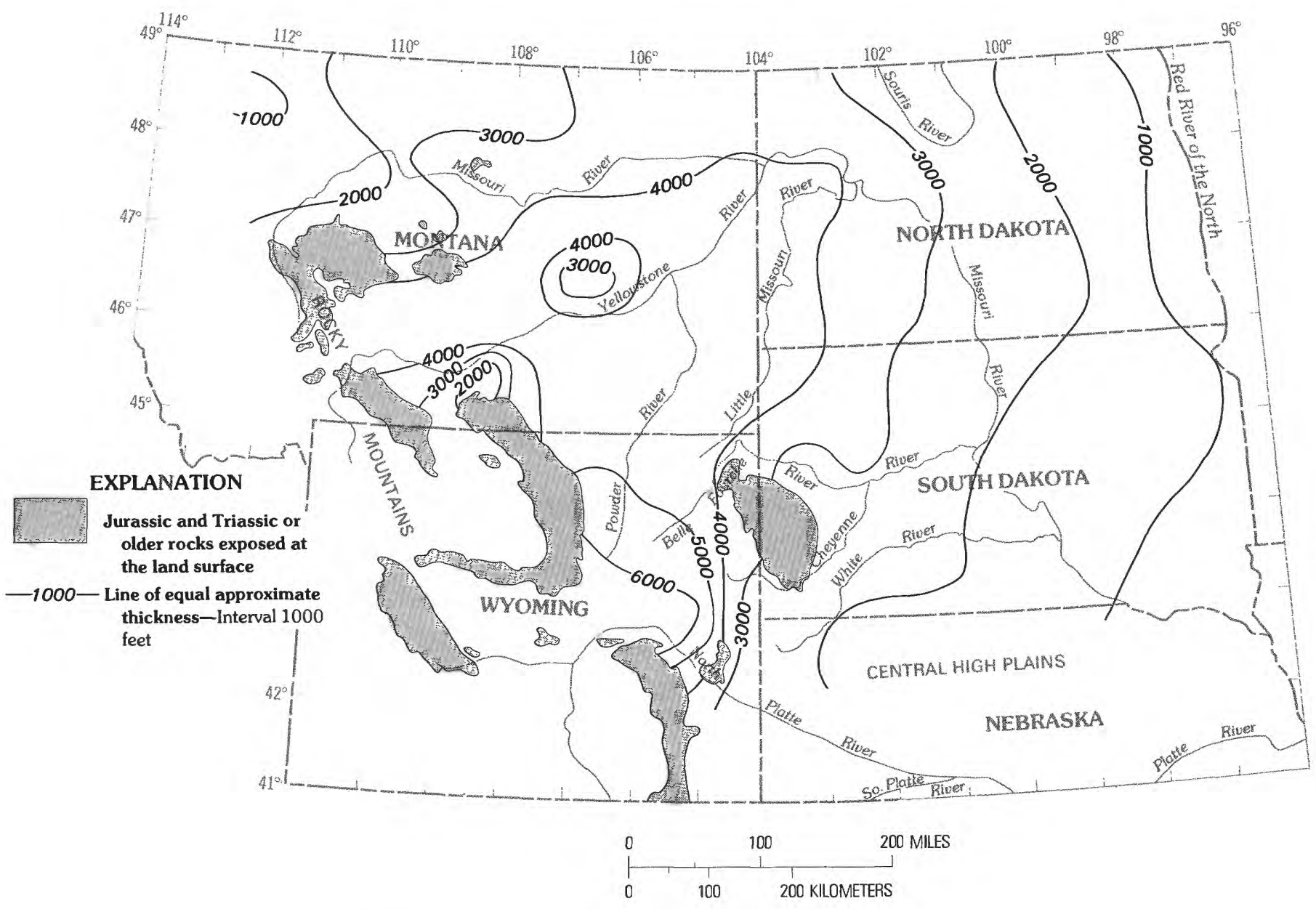

FigURE 9.-Approximate thickness of rocks of Cretaceous age. 
Formation decreases from about $400 \mathrm{ft}$ in central Montana to nearly nonexistence in eastern North Dakota and South Dakota.

The Fall River Formation of Early Cretaceous age represents the initial advance of the Early Cretaceous sea, which deposited fine sand, silt, and clay under shallow-marine, tidal-flat, coastal-swamp, and deltaic conditions. Silt and shale deposits in central Montana and Wyoming indicate a deeper water environment in this part of the study area.

In the Williston basin, analysis of cementation data indicates that these Lower Cretaceous formations have a greater degree of silica cementation than calcite cementation (Anna, 1986). The analysis also indicates that (1) areas of less cementation tend to overlie lineaments, or fracture zones, and (2) areas of more cementation overlie interlineament zones.

The Lakota, Fuson, and Fall River Formations thin eastward, with thickness of the three formations decreasing from about $700 \mathrm{ft}$ in central Montana to near 0 in eastern North Dakota and South Dakota.

The Skull Creek Shale of Early Cretaceous age consists of two marine facies: a lower, glauconitic siltstone, commonly termed basal silt, and an upper shale. The silt facies extends regionally but has increasing sand content in central and south-central Montana. The upper shale facies was deposited under extreme reducing conditions and consists mainly of black organic shale with associated pyrite. The formation ranges in thickness from 0 in eastern South Dakota to more than $250 \mathrm{ft}$ in parts of Montana, Wyoming, and western South Dakota and North Dakota.

Withdrawal of the sea ended deposition of the Skull Creek Shale and resulted in an unconformity separating the Skull Creek Shale from the Newcastle Sandstone in eastern Wyoming and from the Muddy Sandstone in southeastern Montana. Later, the sea transgressed from west to east across the area, with development of extensive delta systems in eastern Montana, northeastern Wyoming, and southeastern South Dakota. Sediment supply to the deltas originated in eastern South Dakota, whereas the deltas supplied sediment to shelf areas in east-central Montana and Wyoming.

Thickness of the Newcastle Sandstone or its equivalent is quite variable, ranging from 0 in large areas of North Dakota to tens of feet in central Montana and Wyoming to an abrupt increase of several hundred feet in southeastern North Dakota and eastern and southcentral South Dakota. Porosity of sandstone beds in the Newcastle Sandstone appears to be greater in areas where Newcastle sand accumulation is thicker. Calcite is a more dominant cementing agent than silica in the Newcastle Sandstone (Anna, 1986).

As the sea transgressed eastward during late
Newcastle time, the dark siliceous shale of the Mowry Shale was being deposited in a large part of the study area. In most of the area, a bentonitic clay marks the top of the Mowry Shale and is used as a regional time marker dividing the Lower and Upper Cretaceous rocks. The Mowry Shale ranges in thickness from 0 in eastern North Dakota and South Dakota to more than $700 \mathrm{ft}$ in central Montana.

The environment at deposition of formations of Late Cretaceous age in the northern Great Plains is associated with four main transgressions and regressions of a shallow sea. The shale and siltstone of the Belle Fourche Shale, Frontier Formation, and Greenhorn Formation were deposited as a continuation of the transgression of the sea during the Late Cretaceous. The Belle Fourche Shale (or equivalent rocks) consists of gray to black marine shale with numerous bentonite beds. The Greenhorn Formation (or equivalent rocks) consists of a thick sandstone sequence with interbedded shale and chalky shale. The Carlile Shale consists of gray marine shale with interbeds of thin sandstone.

The Niobrara Formation ranges in thickness from nearly 0 to about $160 \mathrm{ft}$; it consists of gray marine shale with lenticular chalky beds and is characterized by small white calcareous lenses. Lithologic variations range from a chalk facies in the east to mostly shale facies in the west.

The Pierre Shale directly overlies the Niobrara Formation in the study area. The Pierre consists of more than $3,000 \mathrm{ft}$ of dark, montmorillonitic shale and interbedded sandstone that were deposited under marine conditions. Many of the sandstone units have been given formational status in western and central Montana and in the Powder River basin of Wyoming. Although the Pierre Shale contains a number of sandstone units that act as aquifers in restricted areas, the Pierre acts as a regional confining unit to the underlying Lower Cretaceous aquifer throughout most of the area.

The final regression of the Late Cretaceous sea deposited the Fox Hills Sandstone and the Hell Creek Formation, or Lance Formation, or their equivalent rocks (pl. 2). These formations are areally extensive, with the Fox Hills Sandstone and the Hell Creek Formation cropping out throughout sizable areas in southern and central North Dakota, and the Lance Formation being extensive in Wyoming.

The Fox Hills Sandstone (or equivalent rocks) consists of about $300 \mathrm{ft}$ of deltaic and interdeltaic sandstone, siltstone, and shale. The Hell Creek or Lance ranges from about 350 to $1,500 \mathrm{ft}$ thick and consists of fluvial sandstone, siltstone, and carbonaceous claystone, with occasional thin lenticular coal beds. The Hell Creek or Lance is the meander-belt and delta-plain facies of the Fox Hills delta system. 
On the basis of permeability contrast among formations and the areal extent of the formations, most of the Lower Cretaceous rocks, except Neocomian, were delineated as an aquifer system (fig. $4 ;$ pl. 2 ), and most of the Upper Cretaceous rocks were delineated as a confining unit (fig. 4). However, several formations of the Upper Cretaceous rocks, such as Fox Hills Sandstone and Hell Creek and Lance Formations, were delineated together with Tertiary rocks as an aquifer system (fig. 4 ; pl. 2).

\section{TERTIARY ROCKS}

Tertiary formations (pl. 2) in the northern Great Plains contain important ground-water aquifers for development of domestic and agricultural water supplies; they have a relatively shallow drilling depth, and their water is less mineralized than that in the deeper aquifers. These formations generally were deposited in a continental environment. Exceptions are the Cannonball Member of the Fort Union Formation in western North Dakota, deposited in a marine environment, and the upper part of the Ludlow Member, deposited in a shallow-marine environment. Most of the sediments that make up the Tertiary deposits were derived from highlands to the west and northwest during and after the Laramide orogeny.

The Fort Union Formation of Paleocene age consists of alternating gray to buff sandstone, siltstone, and claystone with thin-to-thick lignite and subbituminous coal beds. Contact with the underlying Cretaceous Hell Creek or Lance is at the base of the lowest persistent coal bed.

Thickness of the Fort Union Formation decreases from more than $3,000 \mathrm{ft}$ in the Powder River basin to less than $300 \mathrm{ft}$ in the Williston basin in central North Dakota and northeast Montana. The sandstone units in the Powder River basin generally are coarser grained and better sorted than in eastern Montana, North Dakota, and South Dakota, and generally are more permeable.

The Wasatch Formation of Eocene age is present only in the Powder River basin and consists of about 1,000 $\mathrm{ft}$ of alternating beds of valley-and channel-fill sandstone, siltstone, and claystone; this formation is similar to the Tongue River Member of the Fort Union Formation, although mineralogical differences have been noted. The contact between the Wasatch Formation and the underlying Fort Union Formation is unconformable and is placed at the top of the Roland-Anderson coal bed (Anna, 1986). This bed is about 50-100 ft thick and is areally extensive throughout most of the southern Powder River basin.
The Golden Valley Formation of Eocene age consists of about $150 \mathrm{ft}$ of kaolinitic claystone, mudstone, lignite, and micaceous sandstone. The formation is present only in western North Dakota and usually as remnants underlying younger rocks. The formation has been subdivided into upper and lower units, the lowermost of Paleocene age and the uppermost of Eocene age.

The White River Formation, or Group where divided, of Oligocene age unconformably overlies the Eocene formations and is about $150 \mathrm{ft}$ thick. The formation is exposed only as erosional remnants, capping buttes in several localities in the Williston basin, and as areally extensive deposits in the Badlands of south-central South Dakota. The White River Group is subdivided into the lower Chadron Formation, consisting of a basal conglomerate with overlying tuffaceous sandstone, siltstone, and shale, and the upper Brule Formation, consisting of claystone, siltstone, and sandstone.

The Arikaree Formation of Miocene age is exposed as remnants resulting from Pliocene and Pleistocene erosion of higher buttes in North Dakota and South Dakota. The formation rests unconformably on the White River Formation and consists of about $250 \mathrm{ft}$ of massive tuffaceous sandstone and siltstone and a few thin beds of quartzite, dolomite, and volcanic ash.

The Ogallala Formation of Miocene age is present only in southwestern South Dakota but is an extensive veneer of interbedded sandstone and claystone throughout most of the central Great Plains region. The Flaxville Formation of Miocene and Pliocene age is a thin widespread pediment capping numerous plateaus and consists of poorly cemented sandstone and conglomerate. The formation is recognized only in northeast Montana but may be correlative to local pediments along flanks of major buttes.

\section{QUATERNARY DEPOSITS}

Deposits of Quaternary age (fig. 10) in the study area consist of alluvium and glacial materials. Alluvial deposits, varying in thickness, fill major drainage of the area. Glacial-till and glacial-outwash deposits occur only in eastern North Dakota, northeastern South Dakota, and northernmost Montana. The outwash deposits can range in thickness from a few feet to several hundred feet and consist of silt, sand, and gravel. Widths of Quaternary deposits generally range from less than 1 to several miles, and they commonly are tens of miles in length. Glacial-outwash deposits are a major source of water in a large part of the study area.

During this study, the Upper Cretaceous and Tertiary rocks and the Quaternary deposits were delineated as a single aquifer system (fig. $4 ; \mathrm{pl}$. 2) overlying the 


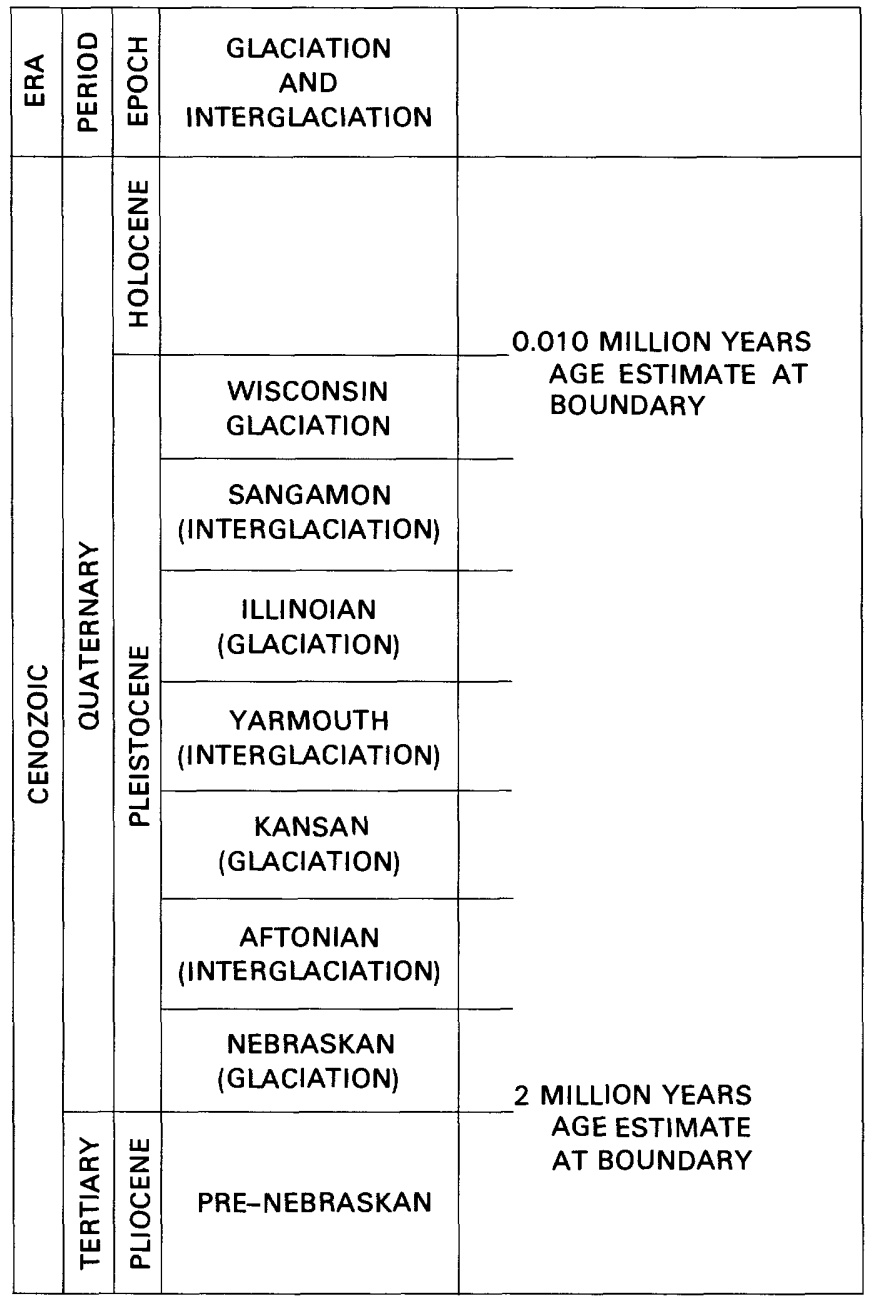

Figure 10.-Pleistocene glaciation and interglaciation units.

low-permeability Cretaceous rocks. No effort was made to delineate aquifers and confining layers among the Upper Cretaceous rocks, the Tertiary rocks, and the Quaternary deposits.

During the Pleistocene Epoch, the hydrologic system in the aquifers of the northern Great Plains was subject to major changes in the recharge-discharge relationships associated with the four glaciations and three interglaciations shown in figure 10 .

At the time of maximum glacial advance, the discharge areas of all the aquifers were covered by thick masses of ice, blocking discharge and causing flow in the aquifers to be southeastward, as shown diagrammatically in figure 11. During interglaciation, glacial ice was absent from the aquifer discharge areas, and the inferred flow direction was northeastward, similar to the flow pattern of the present day, as shown on plate 3 .

Except for local mountain glaciation, the highland areas in the western part of the northern Great Plains were not affected by continental glaciation and continued to be recharge areas for the bedrock aquifers.

\section{GEOLOGIC STRUCTURE}

The structural history of the northern Great Plains is reflected in the sediments. The forces involved in developing geologic structures are among the important factors controlling the distribution of porosity and permeability in carbonate and sedimentary rocks. Movement along structural zones creates porosity and increases permeability by fracturing; this can be modified at a later time by chemical processes occurring in the aquifer as water moves through the fracture system.

Much of the present-day structure in the study area (figs. 12-14) is the result of the Laramide deformation that occurred in Late Cretaceous and early Tertiary time. Many zones of weakness that existed prior to Laramide deformation were the most common avenues for the release of stress during the deformation; northwest-, east-southeast-, and northeast-trending structural features of Precambrian, Paleozoic, and Mesozoic age occur throughout the study area. Many of these structural features were initiated as shear zones of Precambrian age that developed in the basement rocks and since have been zones of weakness. For example, the Nashfork-Hartville fault trend in Wyoming and South Dakota is a component of a broad Precambrian shear zone called the Colorado lineament (Warner, 1978). Warner postulated that this shear zone, which extends from Arizona to the Great Lakes, divides the Precambrian basement into provinces of two different ages, one of 2,400 million years on the north and one of 1,750 million years on the south.

The large fault and lineament systems that have developed in many bedrock units of the northern Great Plains during geologic time are important features in the analysis of the existing hydrologic system. Both faults and lineaments appear to provide paths for increased movement of ground water (Chilingar and others, 1972; Weimer and others, 1982). These features also can be barriers to the flow of water normal to the direction of the fault or lineament. An example of this barrier effect was presented by Konikow (1976) in his analysis of the flow system in the Powder River basin; geologic structure along the eastern edge of the Bighorn Mountains appears to limit water movement from the recharge area in the Bighorn Mountains to the Powder River basin.

Structural movement along major faults and lineaments affects the porosity and permeability distribution throughout a large area and through a long geologic 


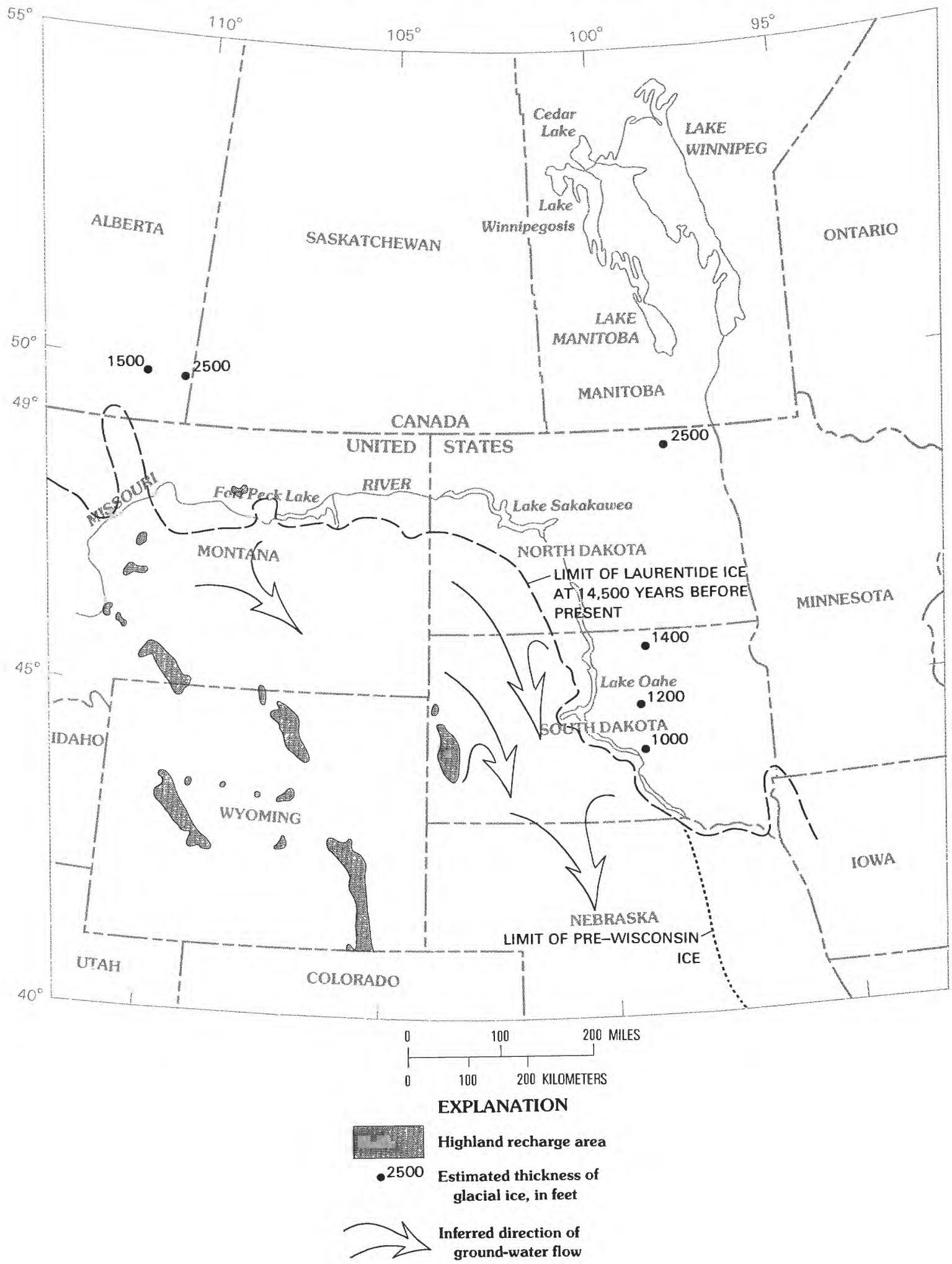

Figure 11.-Extent of Laurentide (Wisconsin) ice in the northern Great Plains and vicinity. 


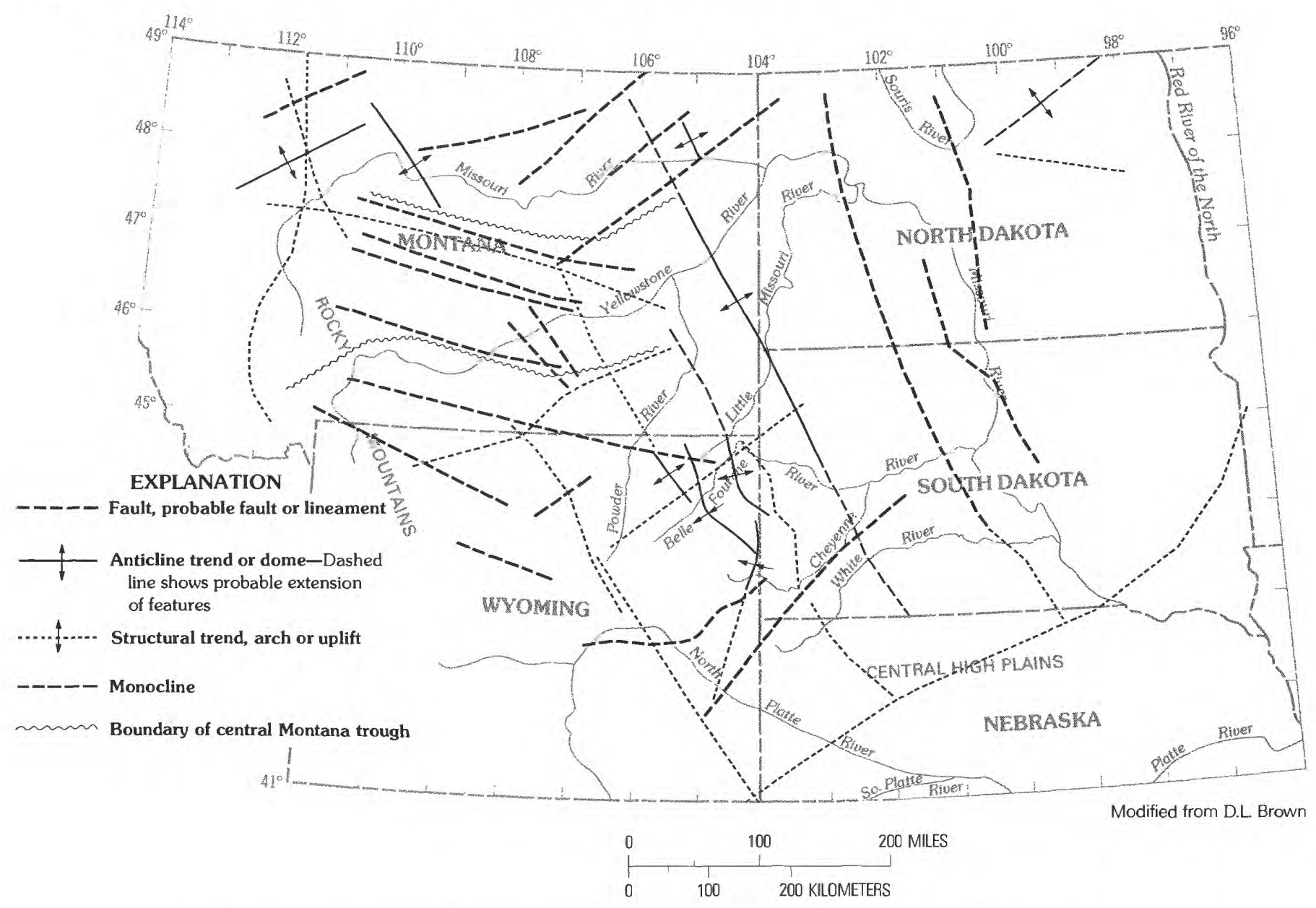

FIGURE 12.-Major Paleozoic structural features in the northern Great Plains and vicinity.

time. Structural adjustments between large blocks of geologic material modify the existing primary porosity and permeability of the rock by fractures or by development of a secondary porosity. Structural adjustments also may result in a decrease in porosity and permeability by precipitation of minerals in rock pore spaces.

Structural movement along or between these large blocks also affected sedimentation of clastic materials, such as those in the Lower and Upper Cretaceous bedrock units. Block movement may result in shallowwater, near-shore environments where coarse-grained sediments are deposited. Later, movement between the blocks may result in a lowered, deep-water environment where fine-grained or calcareous sediments are deposited. Maps drawn by R.K. Blankennagel (USGS, written commun., 1982) show patterns of linear structural trends that apparently relate to changes in sedimentation rates and lithologic type because of adjustments between structural blocks.

Many of the structural features in the northern Great Plains are associated with present-day physiographic features that affect both the deep and shallow groundwater flow systems and surface-water drainage patterns. A set of lineaments-A, B, and C-shown in figure 14 were selected to indicate such effects. Lineament A, which is located in northeastern North Dakota, may be a control on stream channel and lake location in this part of North Dakota. Also, a deep, bedrock trench filled with glacial materials (Downey and Armstrong, 1977) appears to lie along the trend of this feature. This bedrock trench may have been a zone of weakness that was eroded by glacial action during the Pleistocene. Lineament B, a major fault offsetting the eastern flank of the Bighorn Mountains, also affects the surface-water drainage pattern and ground-water flow system in this part of the study area. Lineament C, a major lineament cutting the Black Hills in South Dakota, has a major effect on the ground-water flow system near the Black Hills area.

Carbonate rocks are relatively soluble in water, and the development of karstic features is common wherever these rocks are exposed to the weathering 


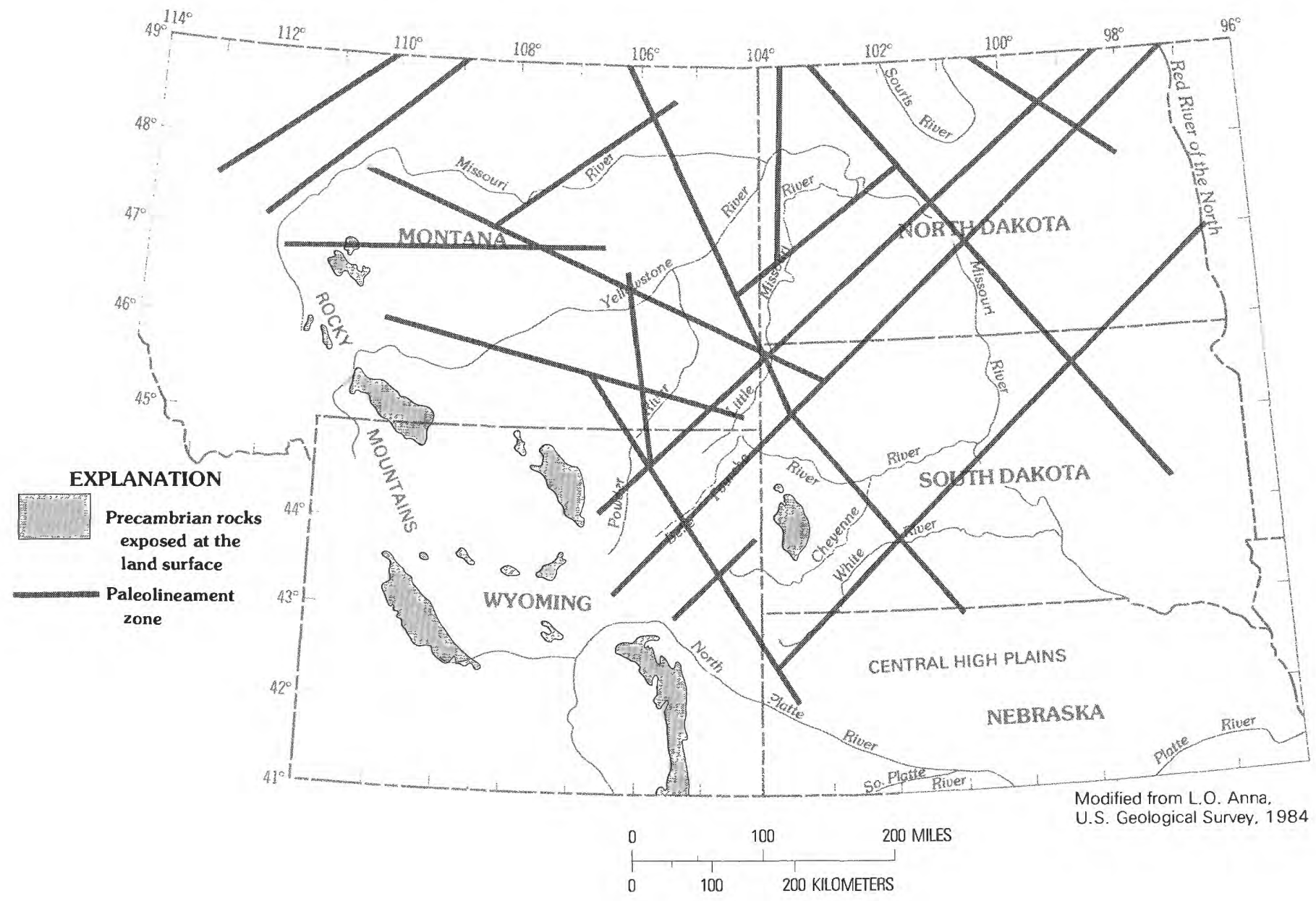

FIGURE 13.-Subsurface paleolineament zones of Jurassic and Cretaceous age in the northern Great Plains and vicinity.

process. The complex interconnected solution features that develop in carbonate rocks during relatively short periods of weathering are illustrated in figure 15 . Sando (1974) described ancient karstic features, including enlarged joints, sink holes, caves, and solution breccias, that developed in the Mississippian limestone in northcentral Wyoming. He further stated that most of the open spaces were filled by sand and residual products reworked by a transgressive sea during Late Mississippian time. Large and extensive cave systems in outcrop areas of carbonate rocks in the Bighorn Mountains and in the Black Hills are further evidence of the importance of the dissolution process in the development of secondary permeability in carbonate rocks underlying the northern Great Plains.

\section{REGIONAL HYDROLOGY}

The confined ground-water system of the northern Great Plains includes numerous permeable horizons, many of which are discontinuous, and all of which vary considerably in hydraulic properties from one location to another. During the study, five major subdivisions (pls. 1 and 2) of the regional aquifer system were made: Cambrian-Ordovician aquifer system; Mississippian aquifer system including Madison Limestone; Pennsylvanian aquifer system; Lower Cretaceous aquifer system; and Upper Cretaceous aquifer system. Each of these is an aggregate of permeable, low-permeable, and semiconfining materials; each has been identified as an aquifer system primarily because vertical head differences within each system tend to be much smaller than those between the adjacent systems. To some extent, the division is arbitrary; it has been made to assist in analysis and discussion of the northern Great Plains regional aquifer system as a whole.

These five major aquifer systems within the regional system make up one of the largest confined aquifer systems in the United States (pl. 3). The flow system extends more than $600 \mathrm{mi}$ from mountainous recharge areas in Montana, Wyoming, and South Dakota to 


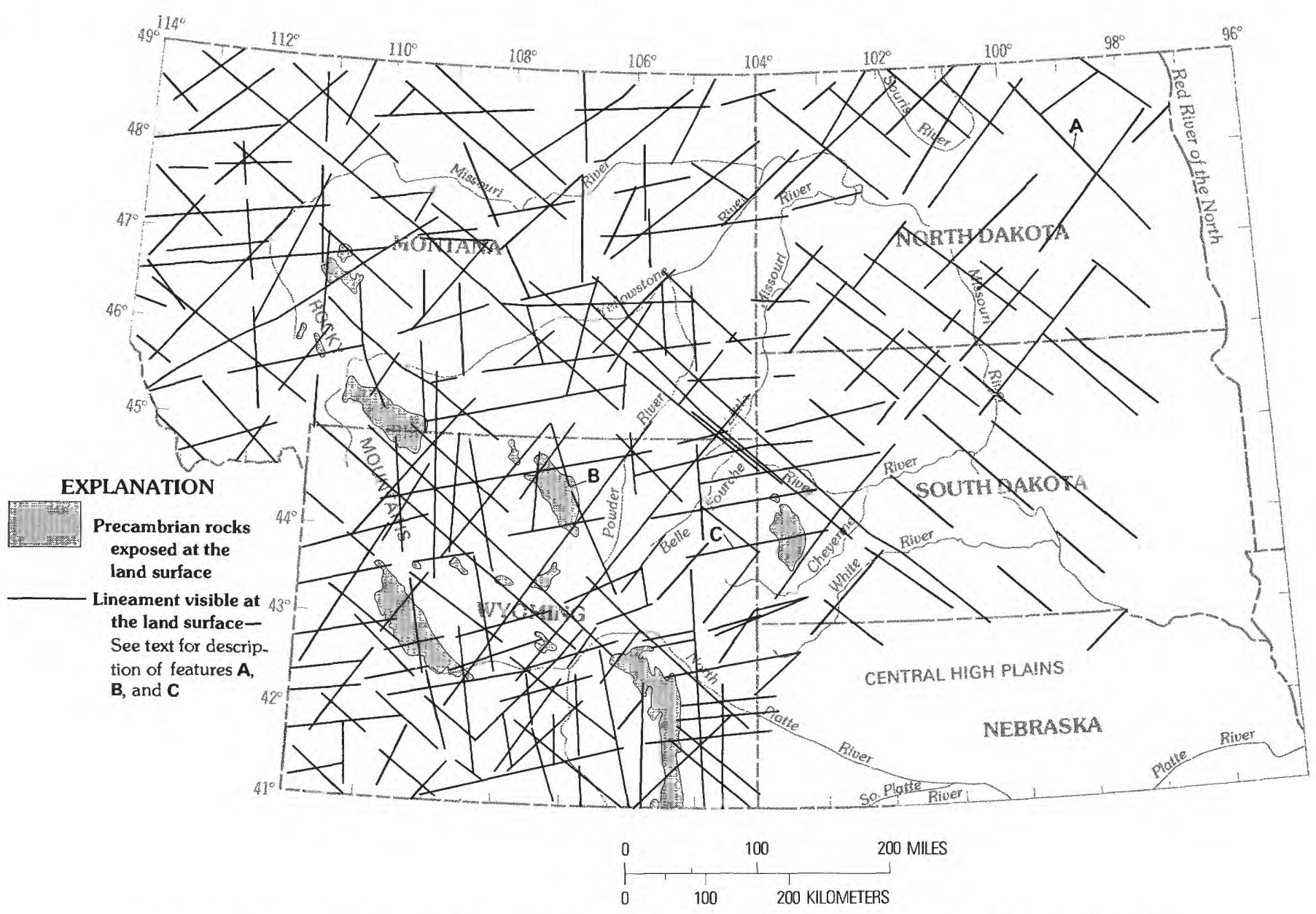

FIGURE 14.-Lineament patterns, delineated using Landsat imagery, in the northern Great Plains and vicinity.

discharge areas in the eastern Dakotas and the Canadian Province of Manitoba. The total area involved is more than $300,000 \mathrm{mi}^{2}$. The geologic units that make up each of the five major aquifers and the intervening semiconfining zones are summarized on plates 1 and 2.

\section{POTENTIOMETRIC SURFACES}

The predevelopment potentiometric-surface maps (before 1950) for the aquifer systems containing rocks of Paleozoic age (figs. 16-18) are those developed by Miller and Strausz (1980a, b). The potentiometricsurface map for the Pennsylvanian aquifer (fig. 19) is from unpublished data developed by W.R. Miller (USGS, written commun., 1980) from drill-stem tests.

The predevelopment potentiometric-surface maps developed by Miller and Strausz (1980a, b) show the altitudes of freshwater heads that were determined from shut-in pressures of drill-stem tests according to a procedure outlined by Miller (1976, p. 17). He used the following equation, modified from Murphy (1965):

$$
h=(\mathrm{FSIP} \times C)-\mathrm{PRD}+\mathrm{LSD},
$$

where

$$
h=\text { altitude freshwater surface in feet above mean }
$$
sea level,

FSIP = final bottom-hole pressure in pounds per square inch,

$C=$ factor to convert FSIP to feet of water,

$\mathrm{PRD}=$ depth to pressure recorder in feet below landsurface datum (LSD),

LSD = altitude of land surface in feet above sea level; land-surface datum.

The factor $C$ equals $2.307 \mathrm{ft}$ of water per pressure increment of $1 \mathrm{lb} / \mathrm{in}^{2}$. It assumes pure water at a temperature of $4{ }^{\circ} \mathrm{C}$ and a density of $1.00 \mathrm{~g} / \mathrm{cm}^{3}$. The resultant map indicates the altitude at which water 


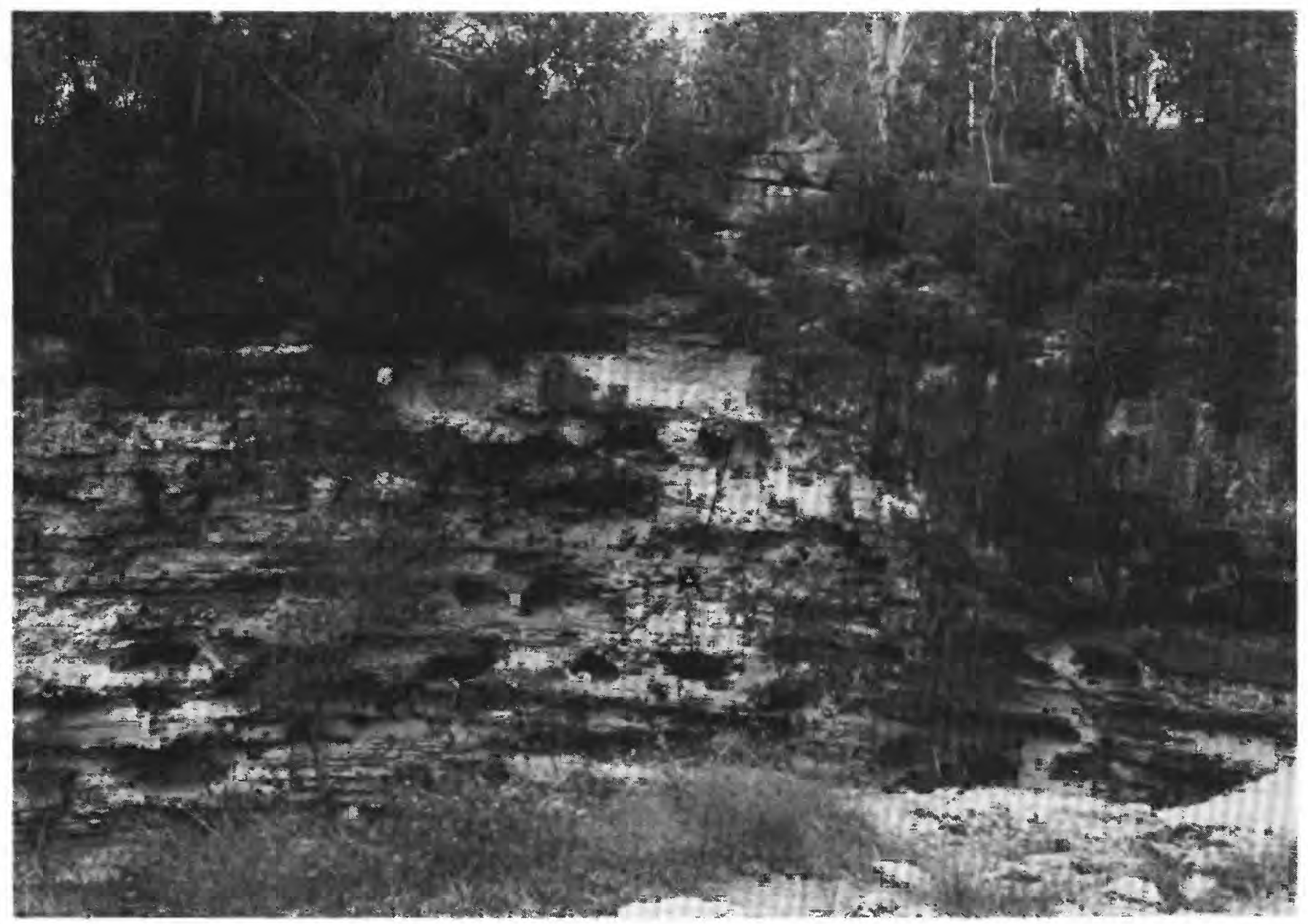

FIGURE 15.-Solution features in marine limestone developed in subtropical conditions similar to those postulated to exist during Late Mississippian time. A, Opening in rock due to removal of limestone by solution. Photograph shows north wall of a cenote, or well, near Chichén Itzá, Yucatán, Mexico.

levels would stand in tightly cased wells open to an aquifer if the water in the well had a density of 1.00 $\mathrm{g} / \mathrm{cm}^{3}$. Gradients of freshwater head in a variabledensity ground-water system are not always proportional to the magnitude of flow, and they do not always indicate the actual direction of flow. However, flow velocity can be calculated from freshwater-head information if fluid density is known throughout the system.

Overall accuracy of the hydraulic-head data shown on the predevelopment potentiometric-surface maps for the Cambrian-Ordovician and Madison aquifers is estimated to be about $\pm 150 \mathrm{ft}$. Accuracy of hydraulic-head data for the Pennsylvanian aquifer and Devonian formations may be less accurate. It should be noted that the predevelopment potentiometric-surface maps are not corrected for chemical-osmotic potential. Chemicalosmotic effects have been suggested (Hitchon, 1969) as the cause for anomalous potentiometric surfaces and salinities in several formations in Canada north of the study area. Berry and Hanshaw (1960) noted a closed potentiometric low in the Lower Cretaceous Viking Formation of Canada that they attributed to the effects of chemical-osmotic forces.

The predevelopment potentiometric-surface data from the Lower and Upper Cretaceous aquifers (figs. 20, 21) are from a report by Lobmeyer (1982). Lobmeyer primarily used data from drill-stem tests and a conversion procedure from pressure to feet of freshwater similar to that used by Miller and Strausz $(1980 \mathrm{a}, \mathrm{b})$ for the aquifer systems consisting of rocks of Paleozoic age. Lobmeyer pointed out that inaccuracies exist in the maps, which are similar to those in the Paleozoic potentiometric-surface maps of Miller and Strausz (1980a, b). He stated that the accuracy of the potentiometric surface shown on the maps is only about \pm 250 $\mathrm{ft}$ in those areas around the Black Hills on the South 


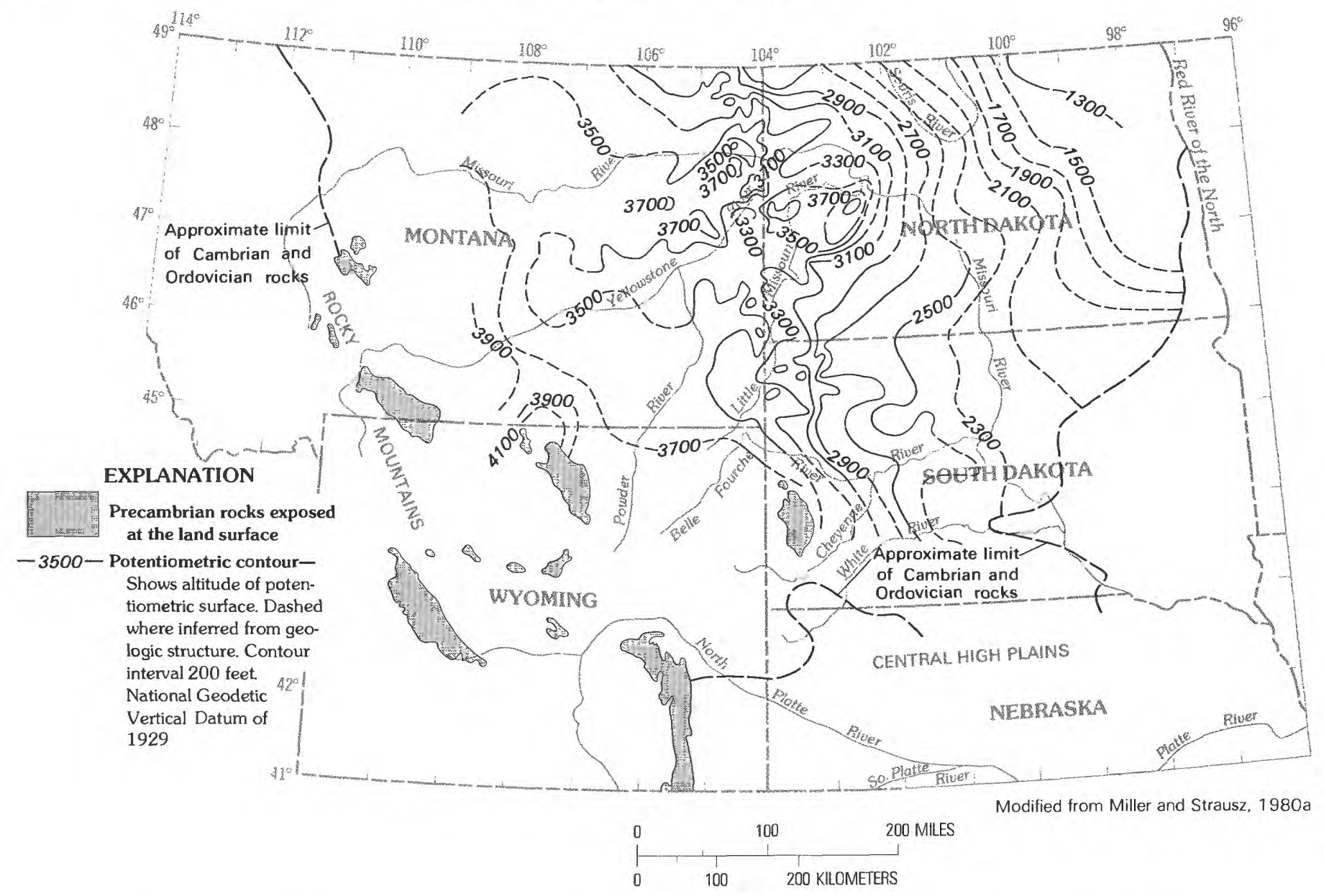

FIGURE 16.-Predevelopment potentiometric surface of the Cambrian-Ordovician aquifer system (before 1950).

Dakota-Wyoming border, around the edge of the Powder River basin, and in central Montana. The Upper Cretaceous potentiometric-surface map is believed to be accurate within one contour interval except where contours are inferred from land-surface altitudes obtained from 1:1,000,000-scale contour maps.

\section{GEOCHEMISTRY}

The geochemical system existing in the aquifers of the northern Great Plains is complex, involving numerous rock-water interactions as water moves along flow paths from the highland recharge areas to the discharge areas. The two principal geochemical mechanisms along all the major flow paths in aquifer systems consisting of rocks of Cambrian through Pennsylvanian age are evaporite dissolution and dedolomitization; however, cation exchange and sulfate reduction also occur at places within the geochemical flow system.

Ground-water temperatures vary considerably in the major aquifers of the northern Great Plains; the maximum temperatures are in the Cambrian-Ordovician (more than $150{ }^{\circ} \mathrm{C}$ ) and Mississippian aquifer systems (more than $130^{\circ} \mathrm{C}$ ) (figs. 22, 23). Because of relatively shallow depths of burial, maximum temperatures of ground water in the Lower Cretaceous (more than $120{ }^{\circ} \mathrm{C}$ ) and Upper Cretaceous aquifer systems (more than $60^{\circ} \mathrm{C}$ ) (figs. 24,25 ) are not as high as those in the deeper aquifers systems consisting of rocks of Paleozoic age.

Solution of halite along the western margins of the Williston basin contributes quantities of sodium chloride to the ground water, forming brines in the deep part of the basin. The brine is associated with the deeper aquifer systems (figs. 26-29) and does not occur in the Triassic and Jurassic formations or in the Lower and Upper Cretaceous aquifer systems (figs. 30-32).

The major conclusions from the geochemistry study are as follows:

1. The chemistry of water from aquifer systems consisting of rocks of Paleozoic through Mesozoic 


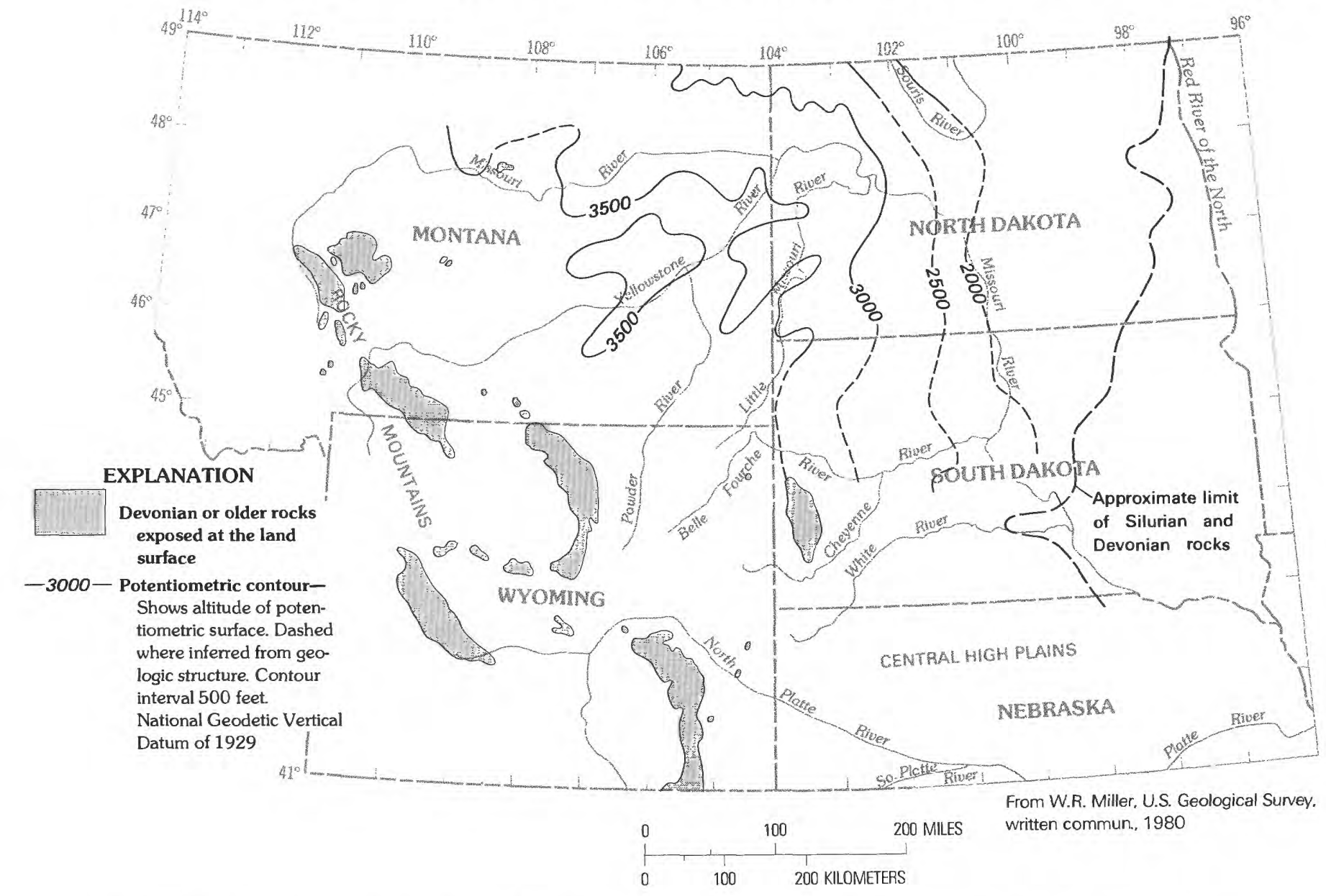

FIGURE 17.-Potentiometric surface derived from measurements of head in locally permeable parts of the Devonian rocks.

age is controlled by a variety of geochemical mechanisms, with dissolution of evaporites and mixing of water being dominant. Although not a dominant control, dedolomitization also is a significant geochemical mechanism.

2. The dominant geochemical control on water from the aquifer systems consisting of rocks of Paleozoic age in Montana and North Dakota is the evaporite deposits of the Central Montana trough and the Williston basin.

3. Geochemical evidence from each delineated aquifer system indicates that sulfate reduction and cation-exchange mechanisms are active.

4. Geochemical evidence indicates that ground-water leakage between the Cambrian-Ordovician, Mississippian, and Pennsylvanian aquifer systems is extensive.

5. The Triassic and Jurassic formations are a confining bed for the underlying aquifer systems.

6. Geochemical data indicate that ground-water flow in Montana is principally from the western recharge areas northeastward toward Canada and eastward toward the Williston basin.

7. Ground-water flow in rocks of Paleozoic and Mesozoic age appears to be relatively slow in North Dakota where the flow probably is diverted northward and southeastward around the Williston basin.

8. With the exception of ground water in comparatively small areas in the immediate vicinity of recharge areas and of ground water in the Williston basin, the dominant type of ground water in aquifer systems consisting of rocks of Cambrian through Pennsylvanian age is a sulfate water (figs. 33-36). Stratigraphically above the Pennsylvanian aquifer are the Lower Cretaceous aquifer system, in which the ground water is generally a mixed type (fig. 37), and the Upper Cretaceous aquifer system, in which the ground water is dominantly a bicarbonate type (fig. 38).

9. Water of the sodium chloride type generally is found within the Williston basin. 


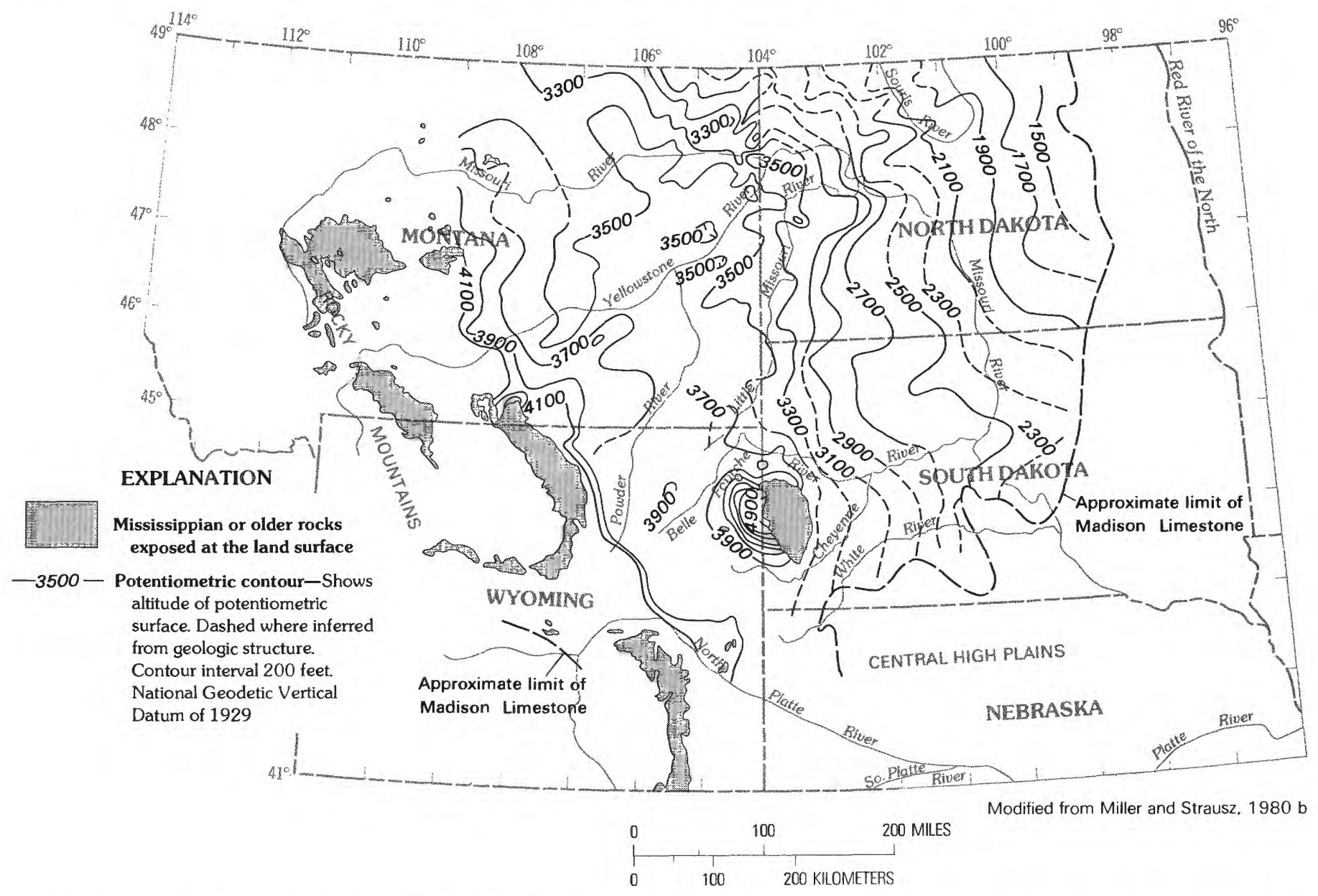

FIGURE 18.-Predevelopment potentiometric surface of the Mississippian aquifer system (including the Madison Limestone) (before 1950).

\section{GEOHYDROLOGY}

The five major aquifer systems (pls. 1, 2) underlying the northern Great Plains area compose one of the largest confined aquifer systems in the United States. The flow system (pl. 3) extends more than $600 \mathrm{mi}$ from mountainous recharge areas in Montana, Wyoming, and South Dakota to discharge areas in the eastern Dakotas and the Canadian Province of Manitoba. The total area of the aquifer system in both countries is approximately $300,000 \mathrm{mi}^{2}$.

All aquifer systems crop out and receive recharge in the highland areas in the western part of the study area (pl. 3). Recharge also occurs in aquifer outcrops in the Black Hills uplift area of South Dakota (fig. 2). The major recharge area for the Madison Limestone (part of the Mississippian aquifer system) in the Black Hills is a plateau on the west flank of the Black Hills uplift where the limestone shows many solution features such as caves and sink holes. The Wyoming State Engineer's Office (1974) states that estimated recharge in an area of 187,000 acres is about 6.8 in. per year, roughly $146 \mathrm{ft}^{3} / \mathrm{s}$. Virtually all eastward-flowing streams draining the recharge areas lose a part of their flow (Swenson, 1968a, b; Wyoming State Engineers Office, 1974) as they cross the aquifer outcrops. Recharge also results from infiltration of precipitation falling directly on the exposed rocks in lowland areas.

Streamflow measurements on several streams draining the east side of the Black Hills (fig. 2) indicate that as much as $10 \mathrm{ft}^{3} / \mathrm{s}$ were lost from the streams as they crossed the outcrop of the Madison Limestone of the Mississippian aquifer system (Swenson, 1968a, b). Prior to a program of stream-channel sealing in 1937, streamflow losses of about $100 \mathrm{ft}^{3} / \mathrm{s}$ were reported by Powell (1940). Based on similar lithology and degree of weathering, it is reasonable to assume that most streams draining comparable western mountainous areas, such as the Bighorn Mountains, would lose similar quantities of flow as they cross the outcrop areas of aquifer systems consisting of rocks of Paleozoic age. Recharge to the Lower Cretaceous aquifer system 


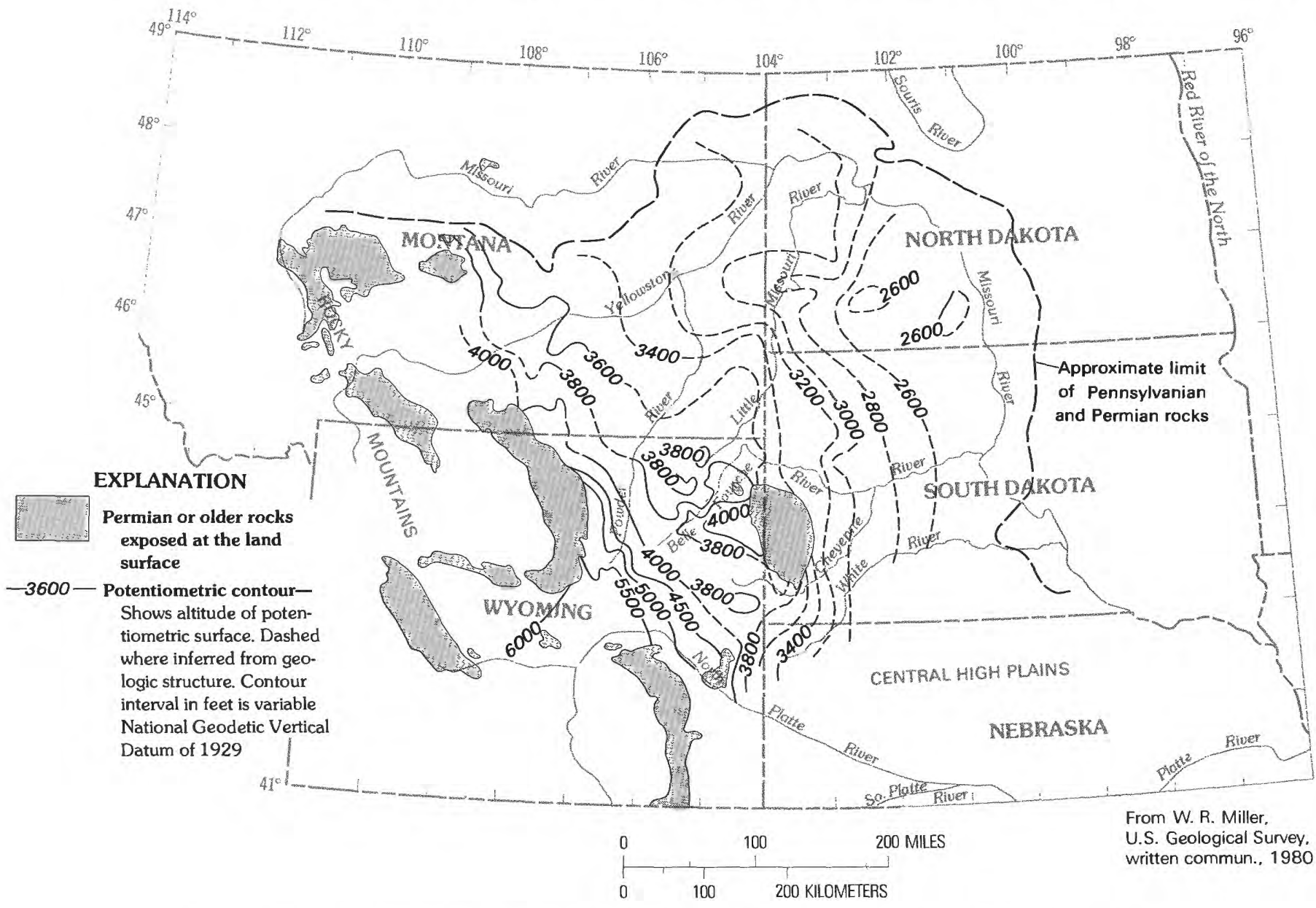

FIGURE 19.-Predevelopment potentiometric surface of the Pennsylvanian aquifer system (before 1950).

takes place by infiltration at outcrop areas and leakage from the underlying aquifer systems. Miller and Rahn (1974) calculated $0.8 \mathrm{in}$./yr of recharge at outcrops of Lower Cretaceous sandstone in the Black Hills. An outcrop area for the Lower Cretaceous aquifer system of about $334 \mathrm{mi}^{2}$ (H.L. Case, III, USGS, written commun., 1982) in the Black Hills area and a recharge rate of $0.8 \mathrm{in} . / \mathrm{yr}$, results in about $20 \mathrm{ft}^{3} / \mathrm{s}$ of recharge to the Lower Cretaceous aquifer system in the Black Hills area. Brown (1944) gaged many streams along the eastern flank of the Black Hills. In contrast to water losses to the Paleozoic aquifer systems, Brown noted that no measurable stream loss from any of the observed streams was detected at the outcrop of Cretaceous rock. It is possible that recharge to the Cretaceous aquifer systems occurs as upward leakage from Paleozoic rocks at shallow depth in the recharge area of the Black Hills. Schoon (1971) postulated that recharge occurs in the Black Hills area but did not distinguish relative quantities of recharge and sources of the recharge.
Although the available data indicate that large quantities of water enter the aquifers along the outcrop areas in the western highlands, not all of this water recharges the deep, regional aquifer system and moves to the eastern discharge area. A large part of the recharged water discharges in a short distance through springs and seeps along the flanks of the mountainous areas (Swenson, 1968a, b; Rahn and Gries, 1973; Hodson, 1974). The fraction of the total recharge that remains in the deeper aquifer systems becomes the regional flow. The diagrammatic expression of the flow conditions (pl. $3 A, B$ ) summarizes the predevelopment (about 1950) flow regime for both the Cambrian-Ordovician and the Mississippian aquifer systems. These flow conditions were synthesized on the basis of digital-model simulations and interpretation of available geologic and hydrologic information.

The rates of recharge shown for selected recharge areas are the infiltration which enters the aquifers in areas where they are close to or at land surface and which remains within the regional-flow system. 


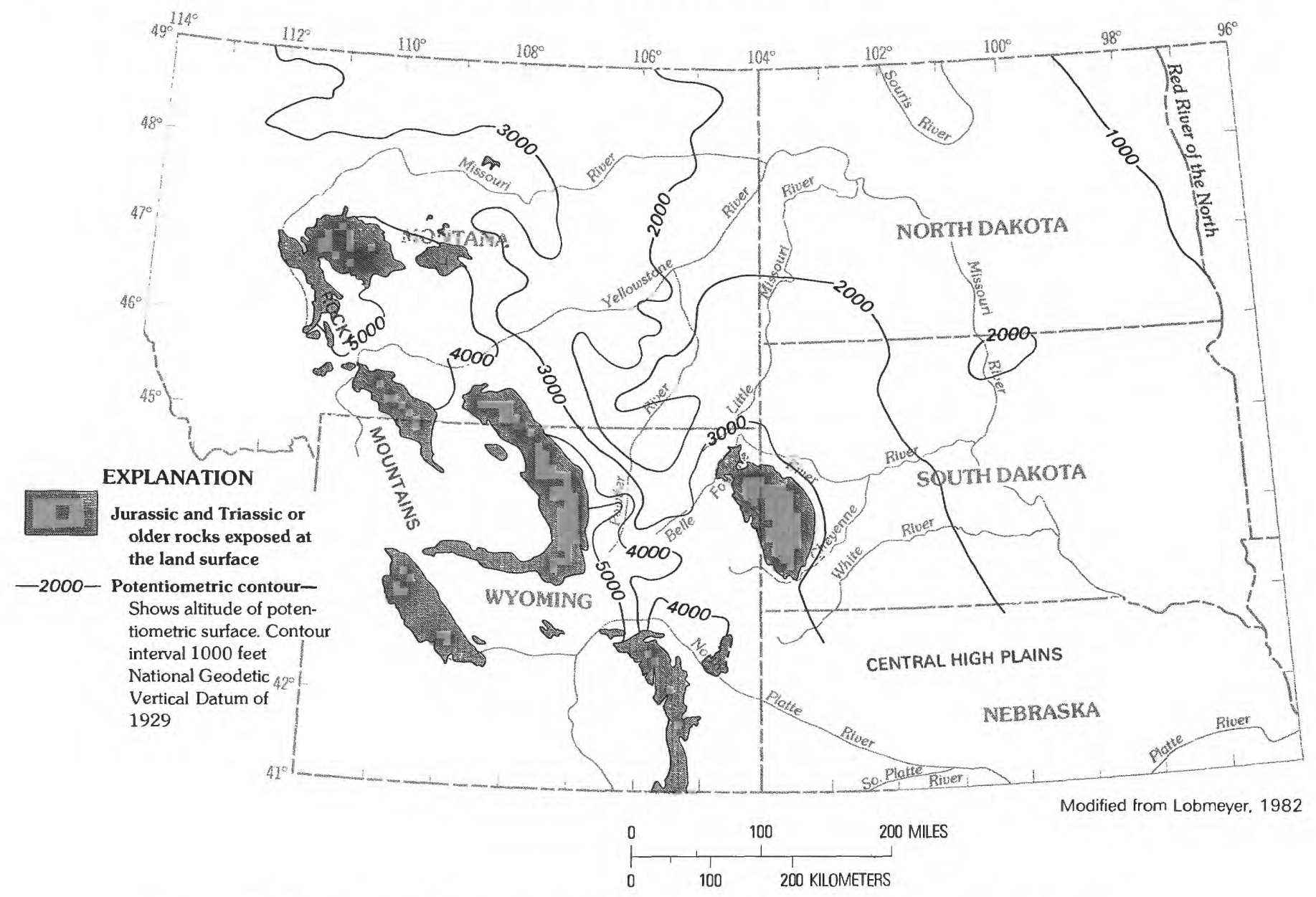

FigURE 20.-Predevelopment potentiometric surface of the Lower Cretaceous aquifer system (before 1950).

Discharge from the Mississippian and Pennsylvanian aquifers is to adjacent and overlying aquifer systems along the eastern subcrops (pl. $3 B, C$ ). Discharge from the Cambrian-Ordovician aquifer system is to adjacent shallow aquifer systems or through springs and seeps in the Lake Agassiz basin of North Dakota and in Canada where the Cambrian and Ordovician formations crop out (pl. $3 A$ ).

Discharge from the Lower Cretaceous aquifer system is mainly upward to the overlying aquifer systems in eastern South Dakota (figs. 39, 40) and along the subcrop of the Lower Cretaceous rocks (fig. 41) in the Lake Agassiz basin of North Dakota (pl. $3 D$ ). At the present time, considerable water is discharged from the Lower Cretaceous aquifer system through unused wells along the Missouri and James River valleys of South Dakota (H.L. Case, III, USGS, written commun., 1982). Discharge estimates from the Lower Cretaceous aquifer system based on model simulation and interpretation of available data are shown on plate $3 D$.

Ground-water discharge through springs located along the outcrop of Paleozoic rocks in the Canadian Province of Manitoba (van Everdingen, 1968) appears to have an effect on the composition of water in Lake Winnipegosis and Lake Manitoba (pl. 3). Water from both lakes contains as much as $600 \mathrm{mg} / \mathrm{L}$ of chloride. Springs along the lakes discharge as much as $0.1 \mathrm{ft}^{3} / \mathrm{s}$ of water with a dissolved-solids concentration ranging from about 29,000 to $63,000 \mathrm{mg} / \mathrm{L}$. The dominant ions present are sodium and chloride. Seven springs located on the shore of Lake Winnipegosis in northern Manitoba were shown by Cole (1915) to discharge about $0.2 \mathrm{ft}^{3} / \mathrm{s}$ from Devonian rocks underlying the lake. Because ground-water flows slow (figs. 42,43 ) and the time since ice covered this area of Manitoba is short $(12,000$ to 14,000 years), it is possible that the water being discharged through springs is a mixture of brine from the deeper part of the aquifer and glacial melt water injected into the aquifer while it was covered by glacial ice. The range in dissolved-solids concentration suggests that the water is a mixture of three flow components: (1) flow from the brine area, (2) injected water 


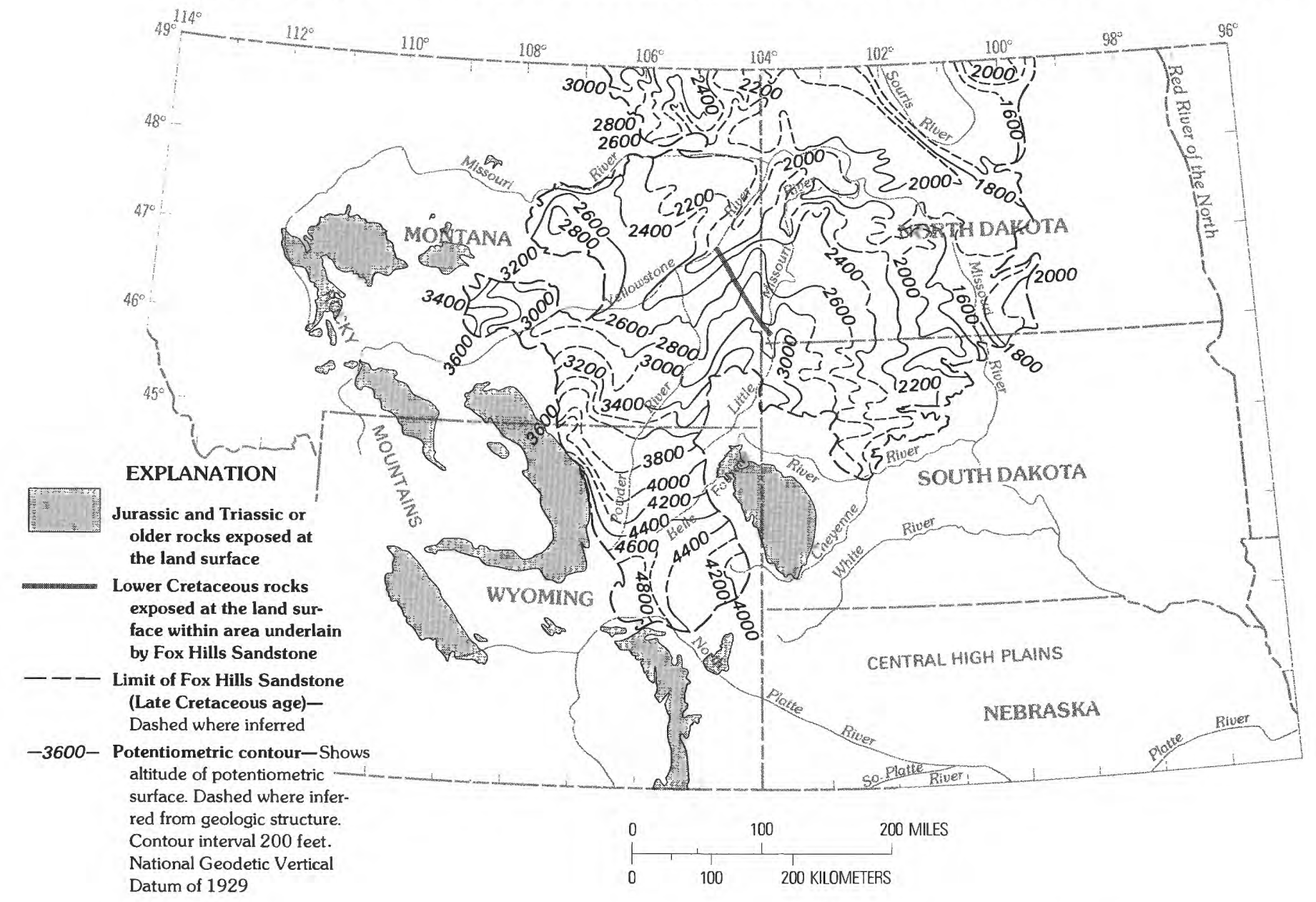

FIGURE 21.-Predevelopment potentiometric surface of the Upper Cretaceous aquifer system (before 1950).

from the Pleistocene glacial ice, and (3) fresher water flowing from the south along a flow path from the Black Hills (pl. $3 A$ ).

The Mississippian aquifer system does not crop out in the eastern part of the study area. The formations that make up the aquifer system terminate in the subsurface and are overlain by younger rocks consisting mostly of Cretaceous shales. Thus, the discharge from the Mississippian aquifer system in this area consists of upward leakage through the overlying confining systems and lateral leakage (pl. $3 A, B$ ) to the CambrianOrdovician aquifer system. Ground-water discharge is concentrated along the eastern rather than the northern limits of the Mississippian aquifer system because stratigraphic unconformities between the Paleozoic aquifer system and the overlying confining systems in the Canadian Provinces of Saskatchewan and Manitoba have resulted in conditions favorable to accumulation of oil and gas in stratigraphic traps (McCabe, 1963). As a corollary to this, conditions in the area of trapping oil and gas must have low-permeability cap rocks, thus being unfavorable for discharge of ground water upward from the Mississippian aquifer system to the overlying aquifer systems.

An area of minimal ground-water flow on the eastern flank of the Williston basin coincides with an area of high concentration of dissolved solids resulting in substantial fluid density (figs. 26, 28, 44). Three hypotheses were considered in explaining the hydrologic flow system in and near the areas of the dense brine. The first hypothesis is that the brine is static and that the hydrologic situation is similar to what was described by Hubbert (1969): freshwater flowing through a synclinal structure comes into contact with static, dense brine along a sharp fluid interface. Hubbert (1969) showed that the body of saline water under these conditions does not lie uniformly in the deepest part of the structure but, rather, is displaced upward along the base of the outflow flank; that is, whereas the inflow flank is occupied entirely by moving freshwater, the 


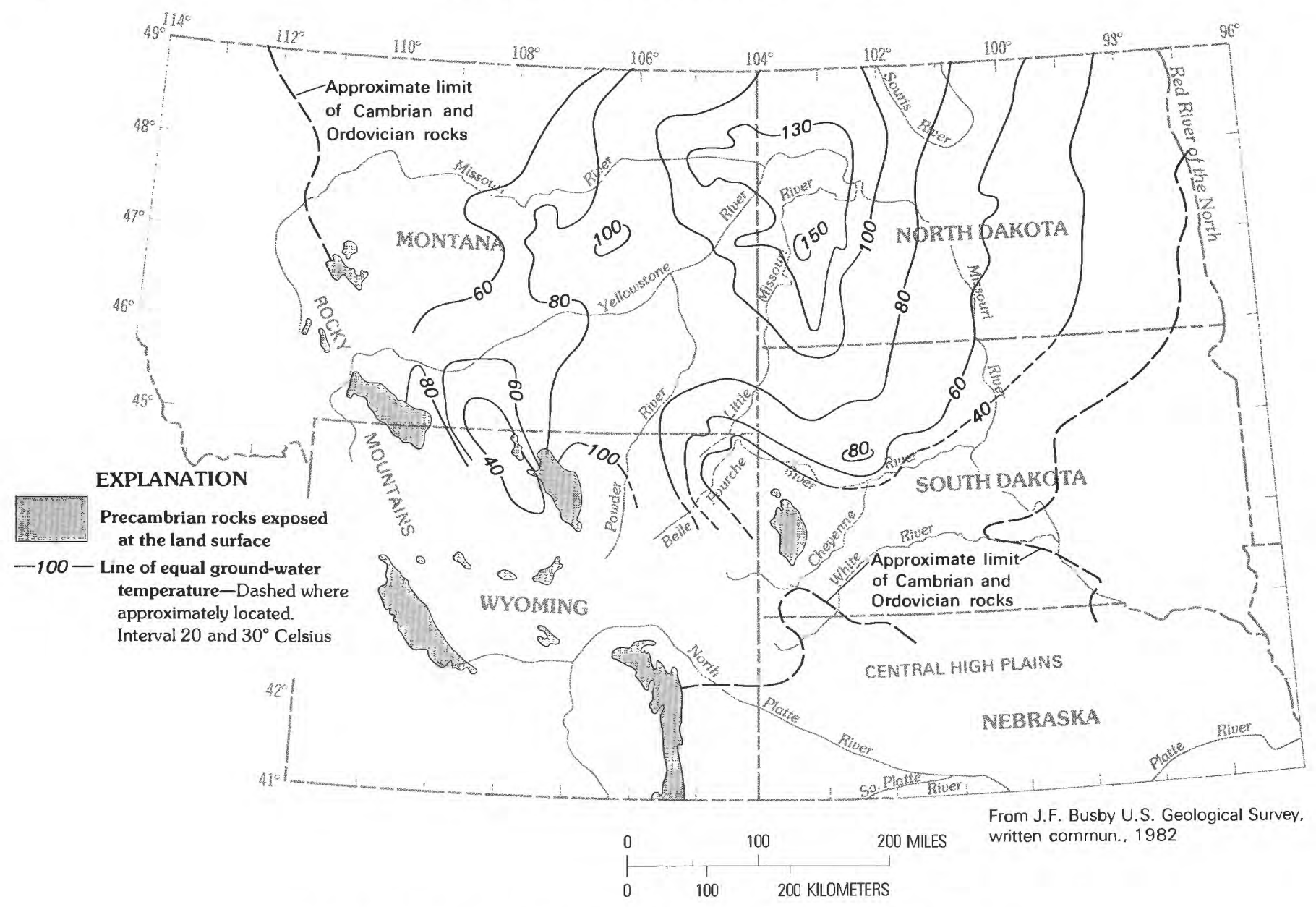

Figure 22.-Water temperatures in the Cambrian-Ordovician aquifer system.

outflow flank contains static brine in the lower part of the aquifer and moving freshwater above. The flow of freshwater in the Williston basin is around the dense brine area, as well as above, and this reflects the fact that the structure is actually a basin rather than the simple syncline analyzed by Hubbert (1969). The flow above the brine apparently is by upward leakage to aquifer systems overlying the Mississippian aquifer system rather than to the upper part of the aquifer system itself. However, model simulations of the flow system indicate slow flow velocities in the brine areas of the Mississippian aquifer system, indicating that the brine is not static as stated in Hubbert's (1969) hypothesis.

Simulation results show slow but consistent flow velocities generally directed to the east and northeast through the dense brine in both the CambrianOrdovician and Mississippian aquifer systems. This indicates that a small component of the regional flow actually moves directly across the Williston basin from west to east through the brine areas. These simulation results suggest a second hypothesis regarding the brine; that is, the brine actually represents a very slow moving segment of the regional flow system. This hypothesis suggests one explanation for the origin of the brine, which can be attributed to solution of salt from halite beds as the water moves through the basin, as described by Grossman (1968). The process of solution of salt is enhanced by increasing water temperature with depth; the maximum salinities are found in regions of maximum temperature. Decrease in salinity in up-dip areas on the eastern flank of the basin presumably is due, at least in part, to precipitation of halite associated with lower temperature, although dilution by fresher water also is undoubtedly a factor. To the extent that precipitation of halite occurs, it should result in a very gradual decrease in permeability during geologic time intervals in the areas where precipitation occurs.

Finally, with regard to the second hypothesis, it should be noted that even though some flow exists, the situation is still similar to Hubbert's static brine hypothesis. Velocities of flow are very low relative to 


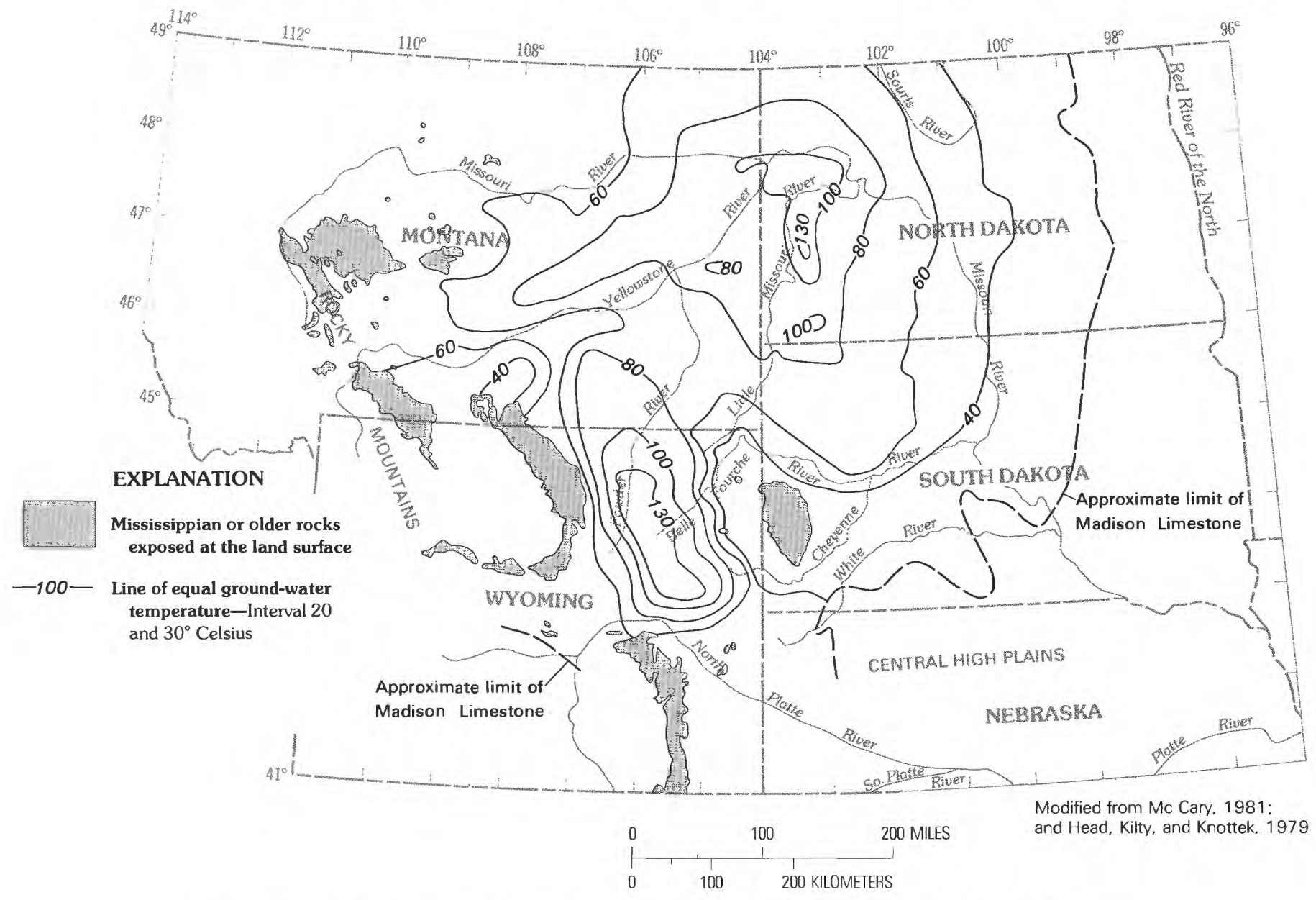

Figure 23.-Water temperatures in the Mississippian aquifer system, including the Madison Limestone.

those elsewhere in the system, and most of the flow of fresher water appears to be deflected around the brine to the north or south or through the confining system into aquifer systems overlying the Mississippian aquifer system. Thus, both the hydraulics and the density distribution seem to be fairly close to what would be observed in a system of totally static brine conforming to Hubbert's (1969) analysis.

A third hypothesis regarding the brine is that it is in motion but that its movement represents an attempt of the system to adjust to changes in recharge and discharge associated with the end of Pleistocene glaciation. These changes were discussed in detail by Downey (1984a). If during Pleistocene glaciation the brine were in a static configuration of the type described by Hubbert (1969), the configuration could not be at equilibrium with the new boundary conditions imposed with the retreat of the ice sheets. Thus, the brine would begin to move at the end of glaciation, seeking a new equilibrium configuration compatible with the new recharge and discharge patterns; this readjustment still could be in progress at present. Such a process could be contributing to some extent to the apparent movement of the brine; however, ground-water flow velocities computed by simulation appear to conform more to the interpretation of a simple flow across the basin than to delayed adjustment to the Pleistocene glacial changes.

In summary, the second hypothesis-that the brine represents a sluggish segment of the regional flow pattern across the basin-seems to agree best with simulation results and with existing field data. Origin of the brine appears to have been the dissolution of halite, and as the density of the brine has increased, undoubtedly it has had an increasing effect on the flow pattern, causing fresher water to divert around it to the north and south or above it into other aquifer systems overlying the Mississippian aquifer system. Although the second hypothesis seems most acceptable, elements of the other hypotheses also are probably reflected in the actual situation. The present configuration of the brine on the outflow side of the basin and its generally slow 


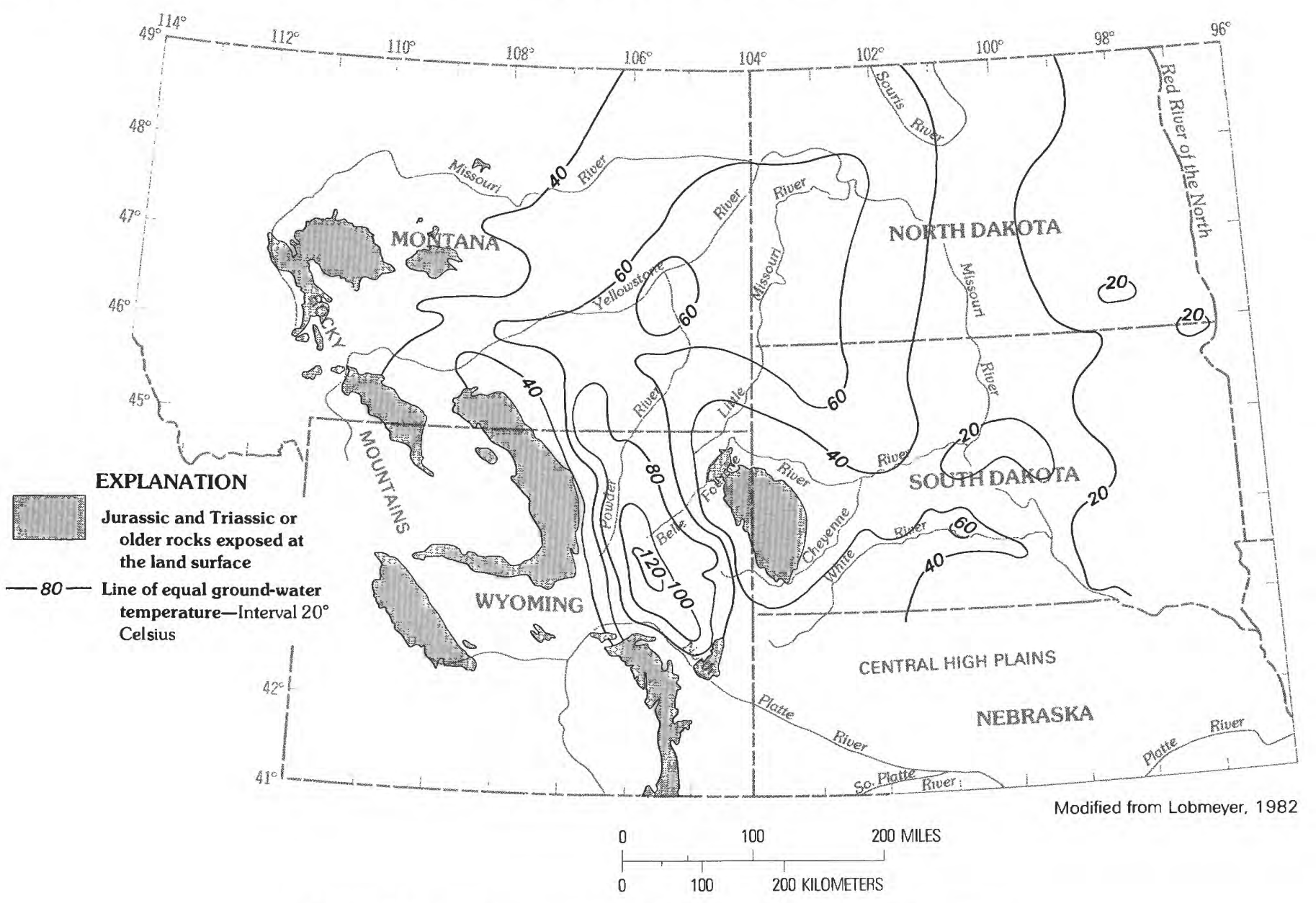

Figure 24.-Water temperatures in the Lower Cretaceous aquifer system.

velocity of ground-water flow approximate the static brine situation described by Hubbert (1969), even though the brine is not totally static; distribution of the saline water still might be shifting in response to changes in recharge and discharge at the end of Pleistocene glaciation.

Saline water also is found in other parts of the study area-for example, in deeper parts of the Powder River basin-although not at the concentration of the brine in the Williston basin. However, similar processes presumably control the saline water's distribution and movement.

Because the highland recharge areas were not covered by major ice sheets (fig. 11) during the glacial stages of the Pleistocene, recharge to the deep aquifer systems from these areas continued. The resulting ground-water flow system (fig. 11) allowed the dissolution of halite along the western edge of the Williston basin to continue during the glacial period; however, because of the short geologic time and the slow flow velocities involved, the brine could not move out of the hydrologic system and tended to remain in the same general location, as shown on plate $3 A$ and $B$.

The flow pattern in the Cambrian-Ordovician aquifer system (pl. $3 A$ ) generally is similar to that in the Mississippian aquifer system, although the CambrianOrdovician aquifer system extends farther to the east and north than the Mississippian aquifer system and crops out in the Canadian Province of Manitoba (fig. 39). A generalized geohydrologic section showing the ground-water movement in the Cambrian-Ordovician aquifer system in North Dakota is shown in figure 41. The location is near the eastern terminus of the Cambrian-Ordovician aquifer, and the figure illustrates the general relationship of the Cambrian-Ordovician aquifer system to shallow ground-water systems and surface-water bodies.

The Cambrian-Ordovician aquifer system contains the same characteristic dense brine as does the Mississippian aquifer system on the eastern flank of the Williston basin (fig. 26). The Cambrian-Ordovician aquifer system apparently discharges in part to a number of saline 


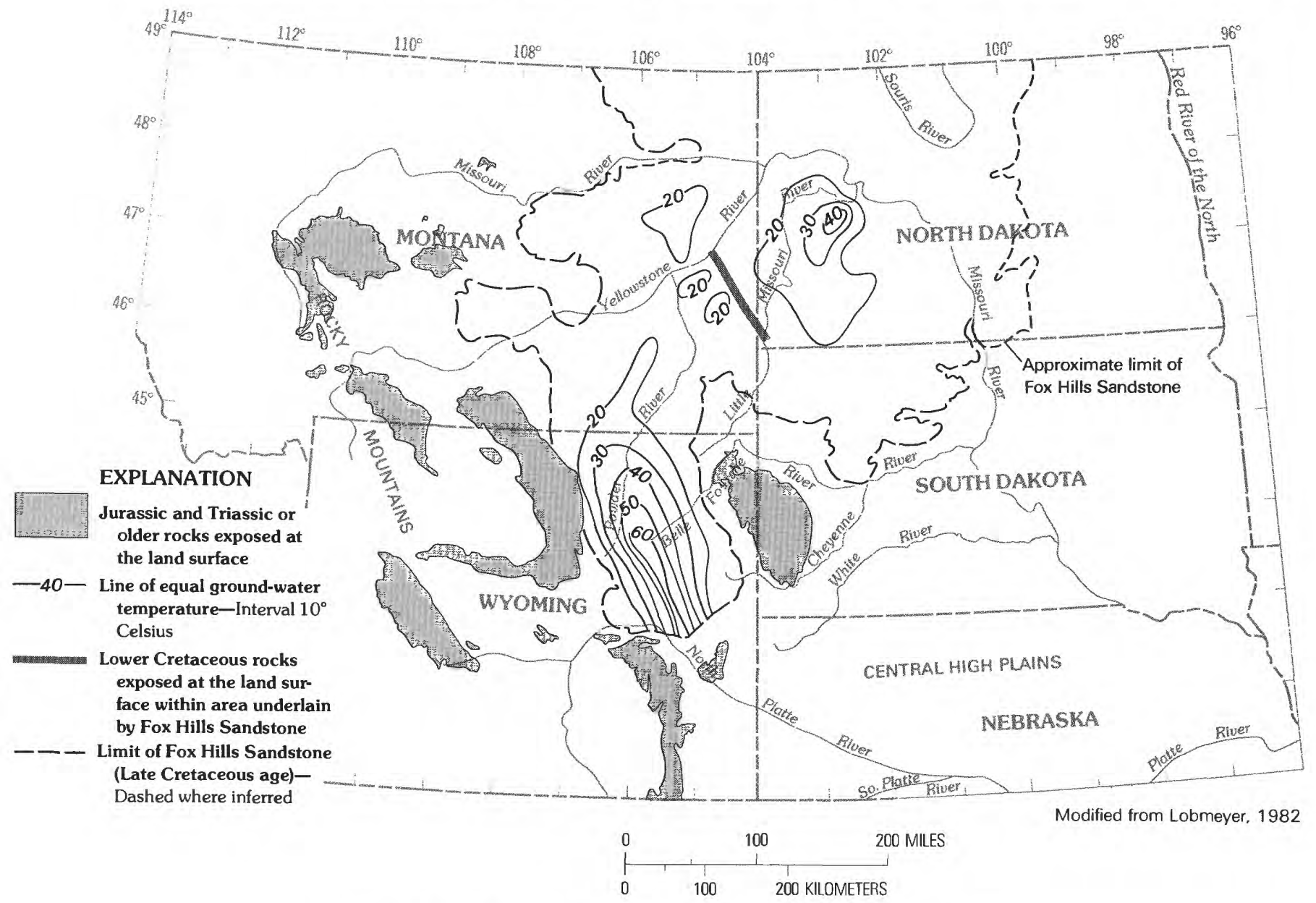

FIgURE 25.-Water temperatures in the Upper Cretaceous aquifer system.

lakes in eastern North Dakota, and the component of flow to the north of the Williston basin is accordingly larger than in the Mississippian aquifer system. The hypothesis of discharge to these lakes is supported by several types of evidence. The saline lakes in question are located in the eastern discharge area of the Cambrian-Ordovician aquifer system (fig. 41 ) and are associated with depressions that overlie deposits of fine sand and gravel. These lake depressions have been attributed to artesian water discharging from deep regional flow systems (Laird, 1944).

A supporting hypothesis is (Downey, 1969, p. 12) that during Pleistocene glaciation of the area, melt water resulting from melting at the base of the ice sheet (Gow and others, 1968; McGinnis, 1968) was forced into the aquifer systems by hydrostatic pressure. After deglaciation, the hydrostatic pressure was greatly decreased, allowing large quantities of water to move rapidly out of the aquifer systems. This relatively rapid movement of water through overlying material resulted in erosion of the overlying lake sediments, forming the depressions in which the lakes exist today. Test drilling indicates that fairly thick deposits of glacial sand and gravel underlie the depressions and are hydraulically connected with underlying bedrock (Downey, 1973). Chemical analyses of water samples collected from the test holes and lakes (Downey, 1971) indicate a chemical similarity to water taken from the Cambrian-Ordovician aquifer system. These analyses indicate that ground water is able to move upward from the deep aquifer systems through the glacial sand and gravel deposits to discharge points at the bottom of the lakes, which in the eastern discharge area function as ground-water drains for the underlying aquifer systems.

The existence of water at the base of continental ice sheets has been suggested by many authors (Robin, 1955; Gow and others, 1968; McGinnis, 1968; Weertman, 1972). The water is the result of melting at the base of ice because of geothermal and frictional heat. McGinnis (1968) estimated that the heat available to a temperate ice sheet from these sources could produce about $0.32 \mathrm{ft}^{3}$ of melt water per square foot of surface 


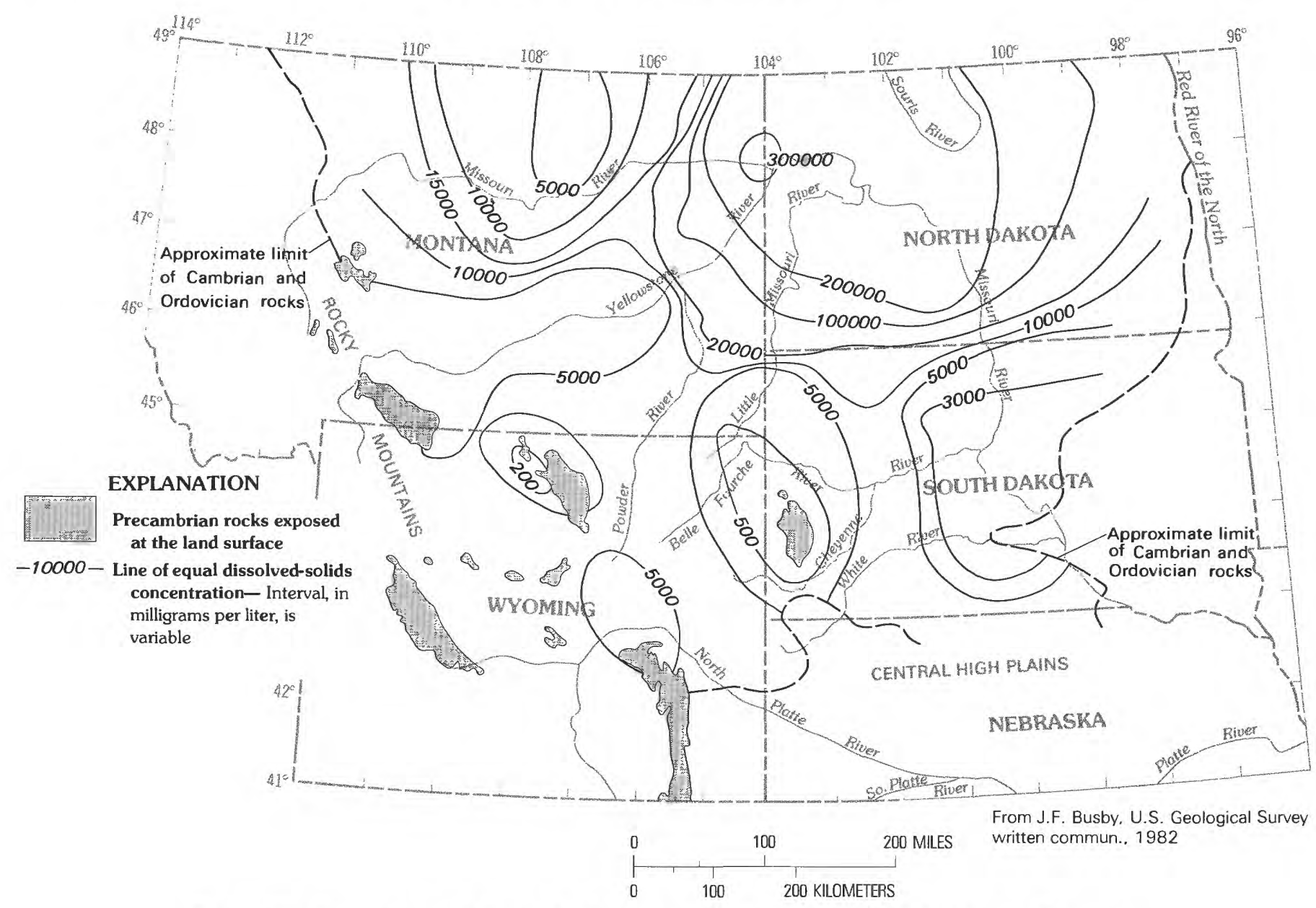

FIGURE 26.-Concentration of dissolved solids in water from the Cambrian-Ordovician aquifer system.

area of the ice sheet per year. The continental ice sheet that existed in the northern Great Plains during the late Pleistocene covered an area of about $121,500 \mathrm{mi}^{2}$ in the United States. Based on $0.32 \mathrm{ft}^{3}$ per square foot of surface area, this analysis results in about $7 \mathrm{mi}^{3}$ of water per year available for recharge to the underlying aquifer systems. The water would be under significant hydrostatic pressure from the weight of overlying ice.

Upward leakage through confining beds appears to be one of the major discharge mechanisms (fig. 39) for all the aquifer systems underlying the northern Great Plains. Vertical leakage between aquifers may be detected by geochemical methods, although the lack of geochemical data for many areas limits definition of the areas of leakage. Leakage occurs both through the confining-bed matrix and along fractures associated with the lineament zones in the confining bed (Weimer and others, 1982). Confining beds are not present everywhere: they were either removed by erosion or they were never deposited. In those areas where the confining beds are absent, such as eastern South Dakota, substantial hydraulic connection exists between aquifers, and leakage may occur from one aquifer to the adjoining one at a rate that is dependent on existing hydraulic-head differences. Where the confining bed is thick and unfractured, leakage through the confining bed is minimal. Leakage along fractures is dependent on the degree of fracturing, the cross-sectional area of the fractures, and the interconnection between fractures.

Geochemical facies maps such as those shown in figures $33,35,36$, and 37 for the Cambrian-Ordovician, Mississippian, Pennsylvanian, and Lower Cretaceous aquifer systems can be used to indicate areas where leakage is occurring between aquifer systems. Similar water types at the same location in adjoining aquifer systems indicate that water is able to move between the two systems through the confining beds at these sites. This type of geochemical data is of value in the adjustment of the vertical-leakage data sets in the calibration of simulation models of the aquifer system.

Halite units, such as those in the Charles Formation, 


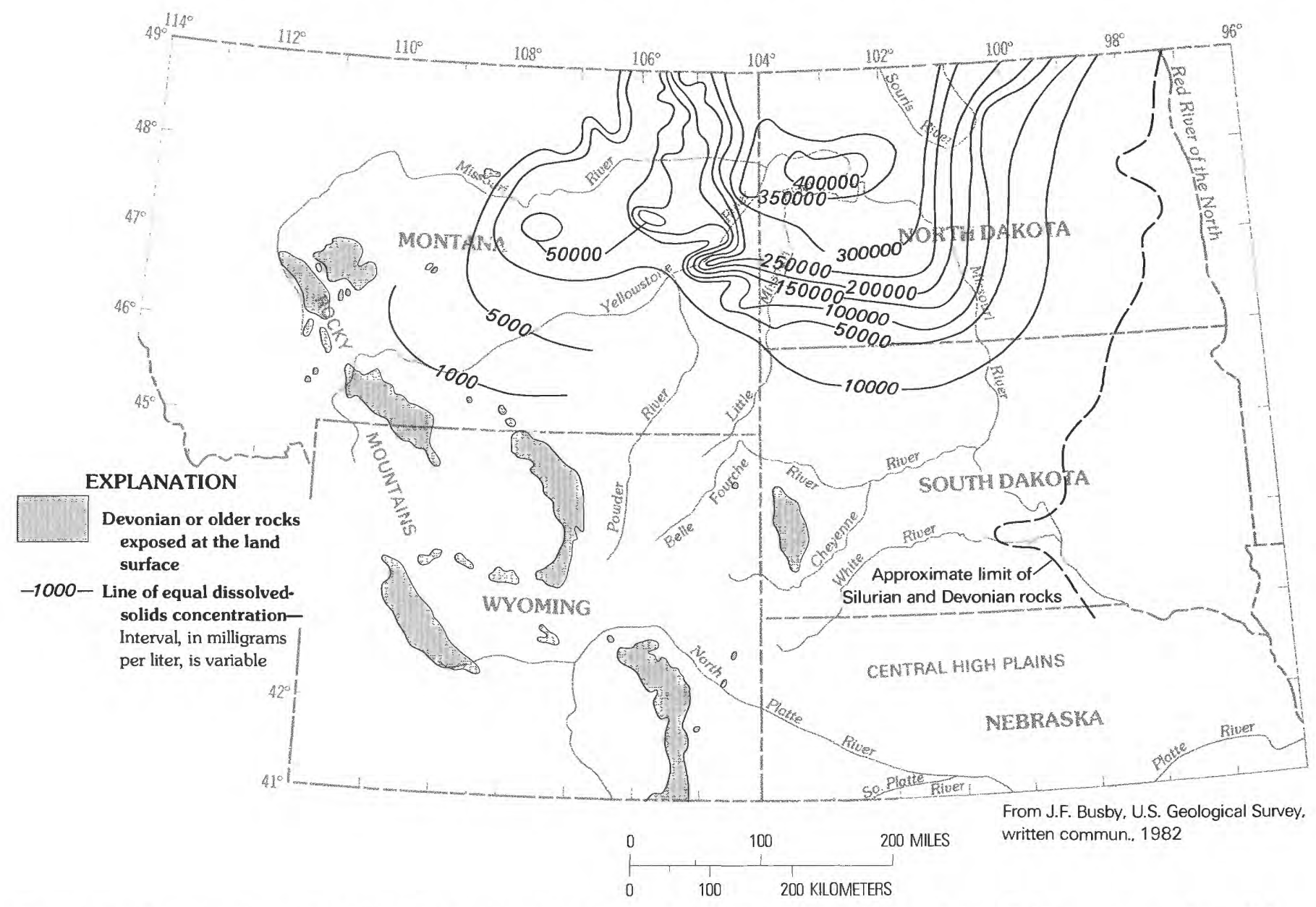

FIGURE 27.-Concentration of dissolved solids in water from the Silurian and Devonian rocks (a major confining system or unit overlying the Cambrian-Ordovician aquifer system).

are considered in this study to be impermeable. However, geochemical evidence (J.F. Busby, USGS, written commun., 1982) indicates extensive leakage between the Cambrian-Ordovician, Mississippian, and Pennsylvanian aquifer systems in the northern Great Plains. The Triassic and Jurassic formations, then, provide the zone of minimal vertical permeability that limits leakage between the aquifer systems consisting of rocks of Paleozoic and Mesozoic age to a very slow rate. Extensive development of the Paleozoic aquifer systems would not affect the Mesozoic aquifer systems in most of the area within a reasonable time frame (40 years). Plans for future development of the deep aquifer systems in the northern Great Plains region need to consider leakage from, and storage in the associated confining beds, because water yielded by the aquifer systems will be derived, in part, from storage in the associated confining beds, except at places where the confining beds are absent or are extensively fractured. Water from the confining beds may have an entirely different chemical quality than water from the developed aquifer system.

Leakage between the Mississippian aquifer system and the Lower Cretaceous aquifer system in eastern South Dakota has been noted in several studies and was the basis for Swenson's (1968a) theory of recharge to the artesian basin of the Dakotas. Swenson suggested that water enters the Madison Limestone in the Black Hills area, moves generally eastward approximately two-thirds across the State of South Dakota, and is discharged by vertical leakage to the Lower Cretaceous (Dakota) aquifer. Swenson's area of discharge from the Mississippian aquifer system to the Lower Cretaceous aquifer system as suggested by simulation results is similar to that shown on plate $3 D$.

In the areas of substantial leakage shown on plate $3 D$, confining beds are thin or absent between the Mississippian aquifer system and the overlying Lower Cretaceous aquifer system. Also, the Pennsylvanian aquifer system is less than $200 \mathrm{ft}$ thick in this area (Swenson, 


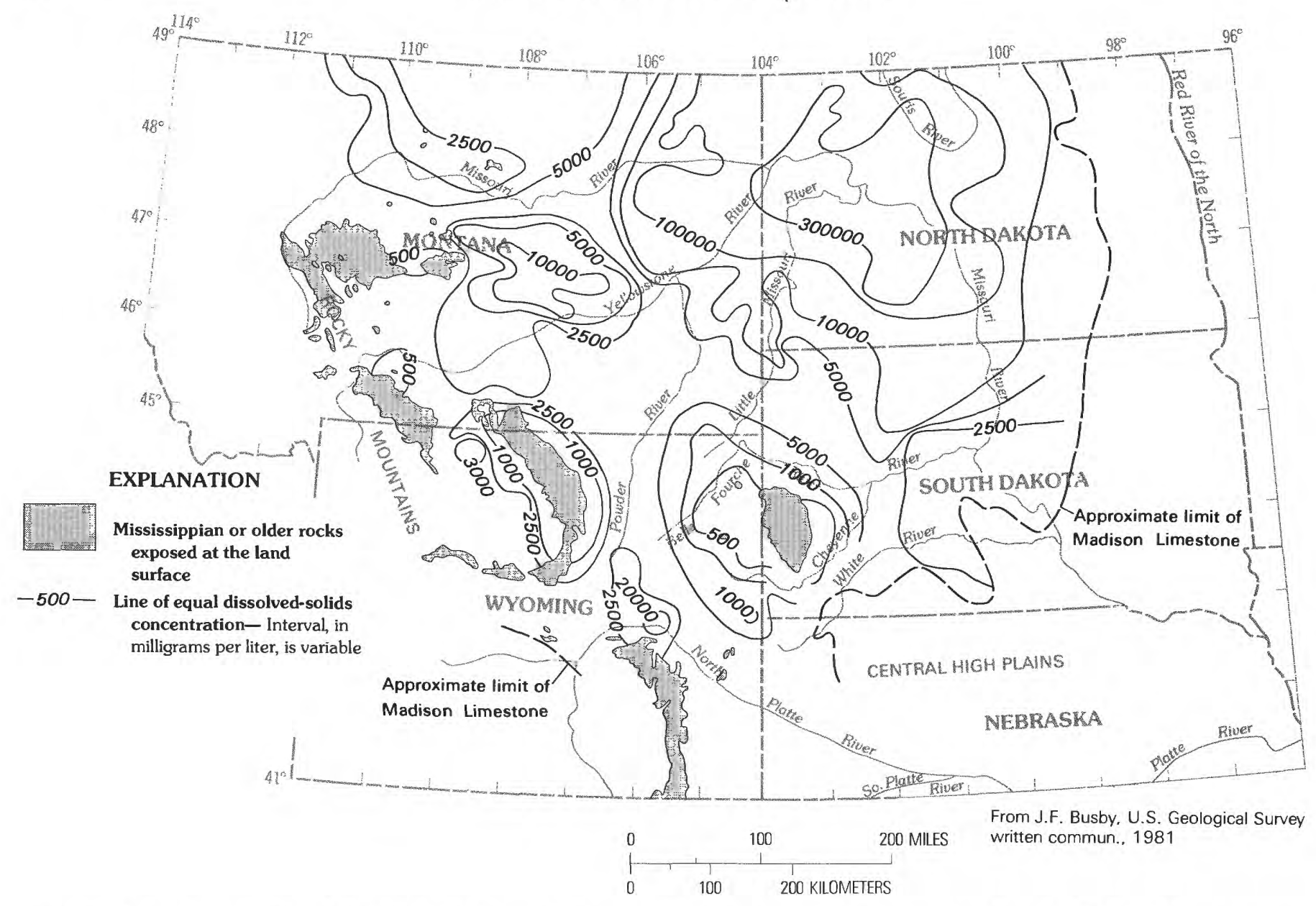

FIGURE 28.-Concentration of dissolved solids in water from the Mississippian aquifer system, including the Madison Limestone.

1968a). Geochemical facies maps (figs. 35, 36) indicate that water from the Pennsylvanian aquifer system is similar to water in the underlying Mississippian aquifer system and that vertical leakage is occurring between these two aquifer systems in this area. Swenson (1968a) presented evidence to indicate water from the Lower Cretaceous (Dakota) aquifer system (fig. 37) is similar in chemical type to that in both the Mississippian and Pennsylvanian aquifer systems in the area of high leakage shown on plate $3 D$.

Except for flow volumes, simulation results indicate that the theory advanced by Swenson (1968a) concerning the ground-water regime in the Lower Cretaceous aquifer system of South Dakota is basically correct. Geochemical data (Swenson, 1968a; K.D. Peter, USGS, written commun., 1982) also support the conclusion that water is moving from the Mississippian and Pennsylvanian aquifer systems to the Lower Cretaceous aquifer system in eastern South Dakota and North Dakota, as illustrated on plate $3 B$ and $D$.

Geologic structure appears to be an important control
(Weimer and others, 1982) of the rate and direction of ground-water movement in the study area. For example, the Casper fault (fig. 2) appears to prevent groundwater flow to the south from the Powder River basin, and the major fault system bounding the Bighorn Mountains on the east (fig. 14, B) limits recharge to the Powder River basin. Recharge from the Bighorn Mountains appears to be channeled by faults and joints associated with major lineament zones and moves northeastward (pl. 3) across the northern part of the Powder River basin (south of the Cedar Creek anticline) to join the flow system from the Black Hills recharge area. This flow system continues around the southern part of the Williston basin northeastward to the discharge area in northeastern North Dakota and eastern Manitoba. The Weldon-Brockton fault zone (fig. 2) appears to be a major conduit for ground-water movement (pl. $3 A, B$ ) from the Big Snowy Mountains and associated highland areas in Montana to discharge areas in Canada north of the Williston basin. The reader may refer to Professional Paper 1402-E for a detailed 


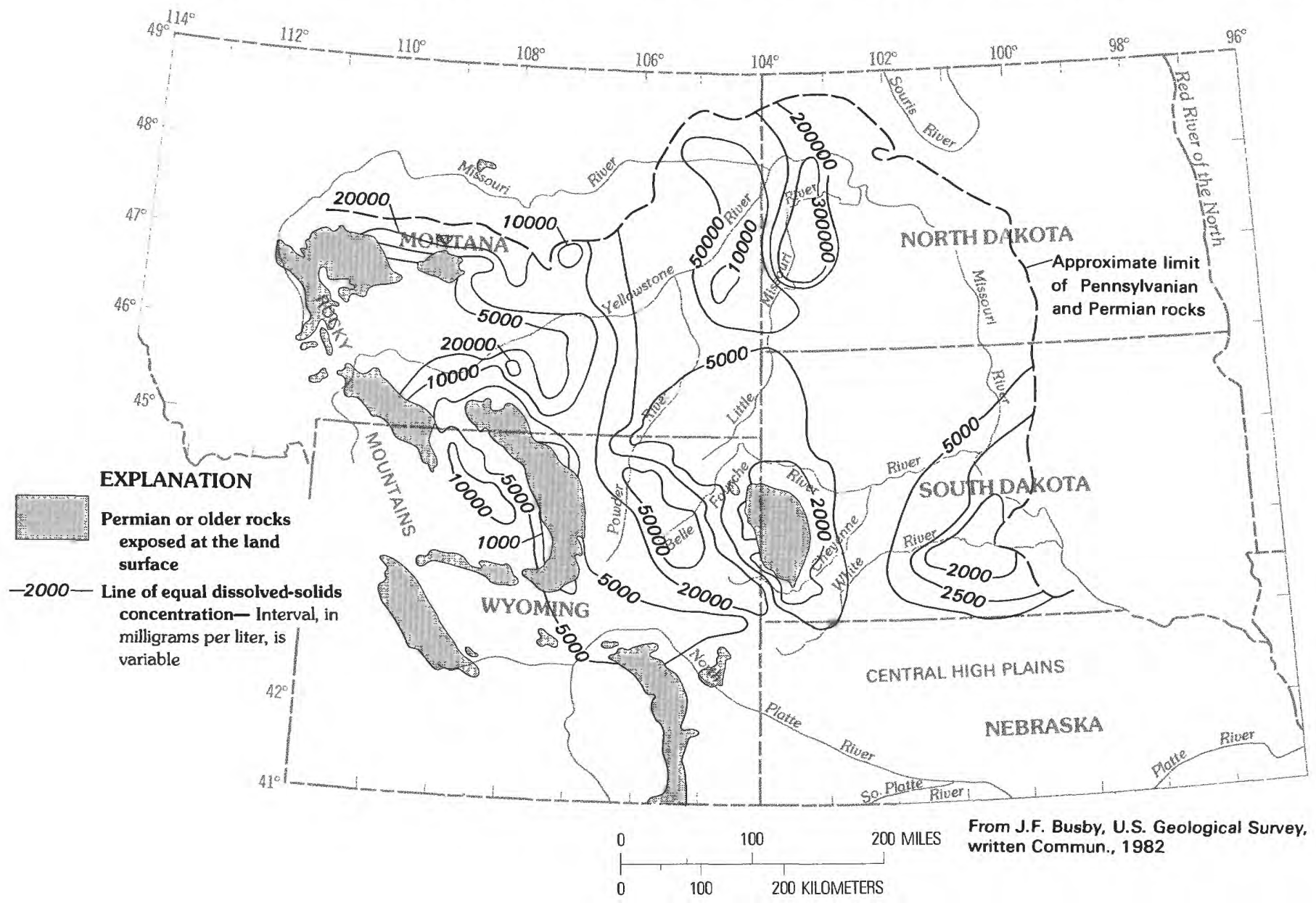

Figure 29.-Concentration of dissolved solids in water from the Pennsylvanian aquifer system.

discussion of these structural effects on ground-water movement.

\section{SIMULATIONS}

A calibrated digital simulation model such as the one developed for the northern Great Plains aquifer system can be used to evaluate the effects of planned development of the system provided the initial and boundary conditions, hydraulic parameters, and other needed hydrologic data can be specified. The accuracy of the evaluation depends primarily on the accuracy of the model input data. If a model is calibrated with accurate data-where the hydraulic head, transmissivity, leakage, and storage coefficient are accurately known, or where the error range of each parameter is known-then the evaluation by the model will be reliable within the range of acceptable error.

During the study of the northern Great Plains regional aquifer system, only hydraulic-head data were reasonably accurate. The other hydraulic parameters were estimated on the basis of field experience and were constrained by a reasonable range of each parameter; therefore, the digital simulation model is not considered to be fully calibrated. Nevertheless, the model was useful for understanding the aquifer systems and for estimating the effects of future development of the regional aquifer system.

To illustrate this potential, hypothetical simulations were made. Figures 45-47 indicate the effects on the Pennsylvanian and Cambrian-Ordovician aquifer systems if the Mississippian aquifer system is developed with a hypothetical pumping rate of $27.9 \mathrm{ft} / 3 / \mathrm{s}$ for continuous pumping of 5.9 years. The storage coefficient of the Mississippian aquifer system was assumed to be $2.0 \times 10^{-6}$. The effect on the Cambrian-Ordovician aquifer system is much greater than the effect on the Pennsylvanian aquifer system (figs. 48, 49). If the value of the storage coefficient of the Mississippian aquifer system is increased by two orders of magnitude from $2.0 \times 10^{-6}$ to $2.0 \times 10^{-4}$ with all other conditions kept the 


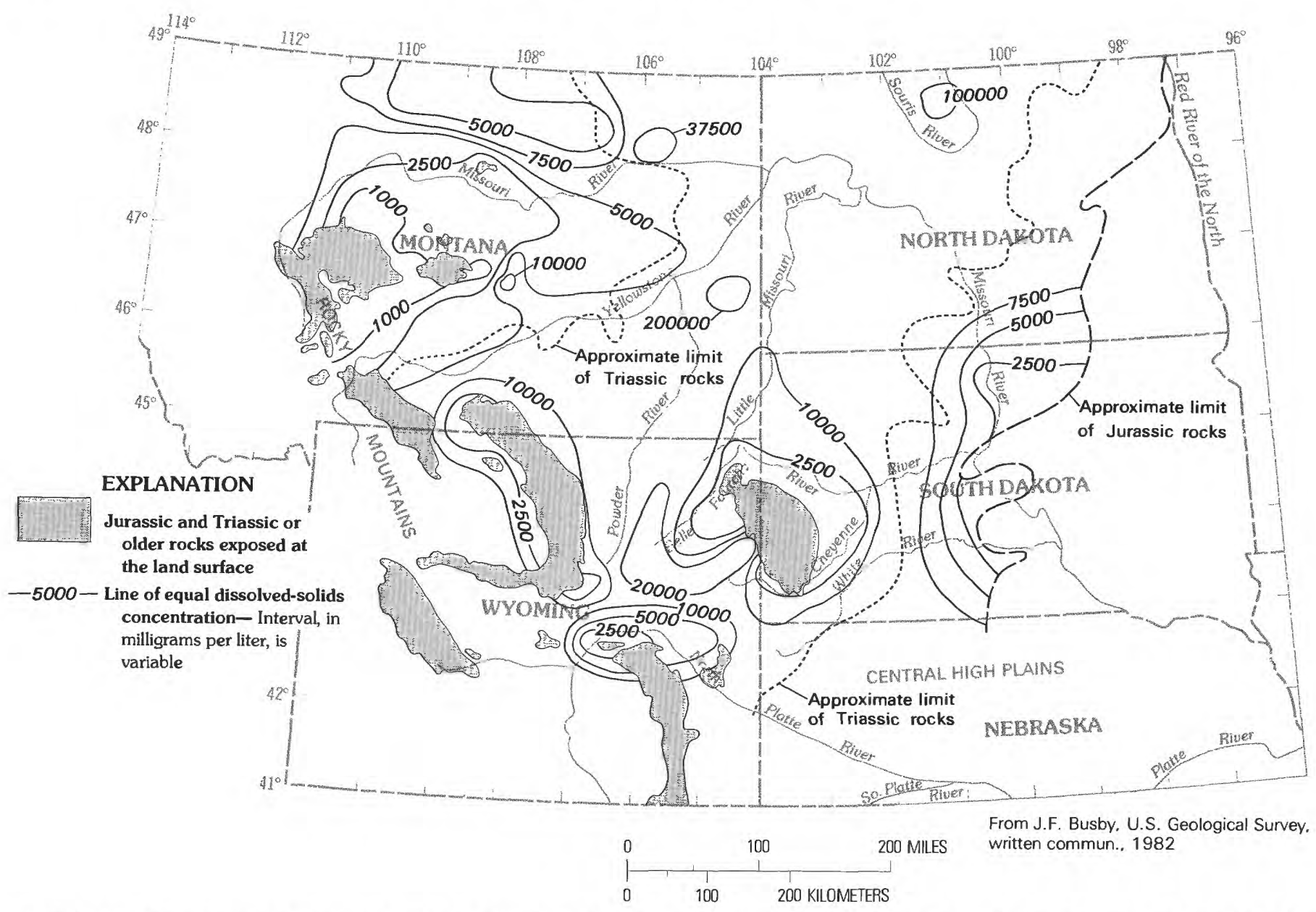

Figure 30.-Concentration of dissolved solids in water from the Triassic and Jurassic rocks (a major confining system or unit overlying the Pennsylvanian aquifer system).

same, the development effects on the Pennsylvanian aquifer system become negligible, and the effect on the Cambrian-Ordovician aquifer system is also reduced dramatically, as shown in figure 49. Even the drawdown in the Mississippian aquifer system is reduced significantly, as shown in figure 48 , indicating that the value of the storage coefficient is important for using the model to evaluate the development effects. The reader should refer to Professional Paper 1402-E for a detailed discussion on model simulations.

\section{SELECTED REFERENCES}

Adolphson, D.G., and LeRoux, E.F., 1968, Temperature variations of deep flowing wells in South Dakota, in Geological Survey research 1968: U.S. Geological Survey Professional Paper 600-D, p. D60-D62.

Agatston, R.S., 1954, Pennsylvanian and Lower Permian of northern and eastern Wyoming: American Association of Petroleum Geologists Bulletin, v. 38 , no. 4, p. $508-583$.
Agnew, A.F., and Tychsen, P.C., 1965, A guide to the stratigraphy of South Dakota: South Dakota State Geological Survey Bulletin $14,195 \mathrm{p}$.

Alpha, A.G., 1955, Tectonic history of north central Montana: Billings Geological Society Annual Field Conference, 6th, 1955. Guidebook, p. 129-142.

1958, Tectonic history of Montana: Billings Geological Society Annual Field Conference, 9th, 1958, Guidebook, p. 57-68.

Anderson, E.M., 1951, The dynamics of faulting and dyke formation with applications to Britain: Edinburgh, and London, Oliver and Boyd, 206 p.

Anderson, S.B., 1954, Stratigraphic sections of the Mississippian system in North Dakota: North Dakota Geological Survey Report of Investigation 16, 2 sheets.

1969. The Newcastle Formation in North Dakota: Montana Geological Society Annual Conference, 20th (Eastern Montana Symposium), Billings, Mont., 1969, Proceedings, p. 77-83.

Anderson, S.B., and Hunt, J.B., 1964, Devonian salt solution in northcentral North Dakota, in International Williston Basin Symposium, 3d, Regina, Saskatchewan, 1964, Proceedings: Billings, Mont., Billings Geological Society, p. 93-104.

Anderson, S.B., and Swinehart, R.P., 1979, Potash salts in the Williston basin: Economic Geology, v. 74, no. 2, p. 358-376. Andrichuk, J.M., 1951, Regional stratigraphic analysis of the 


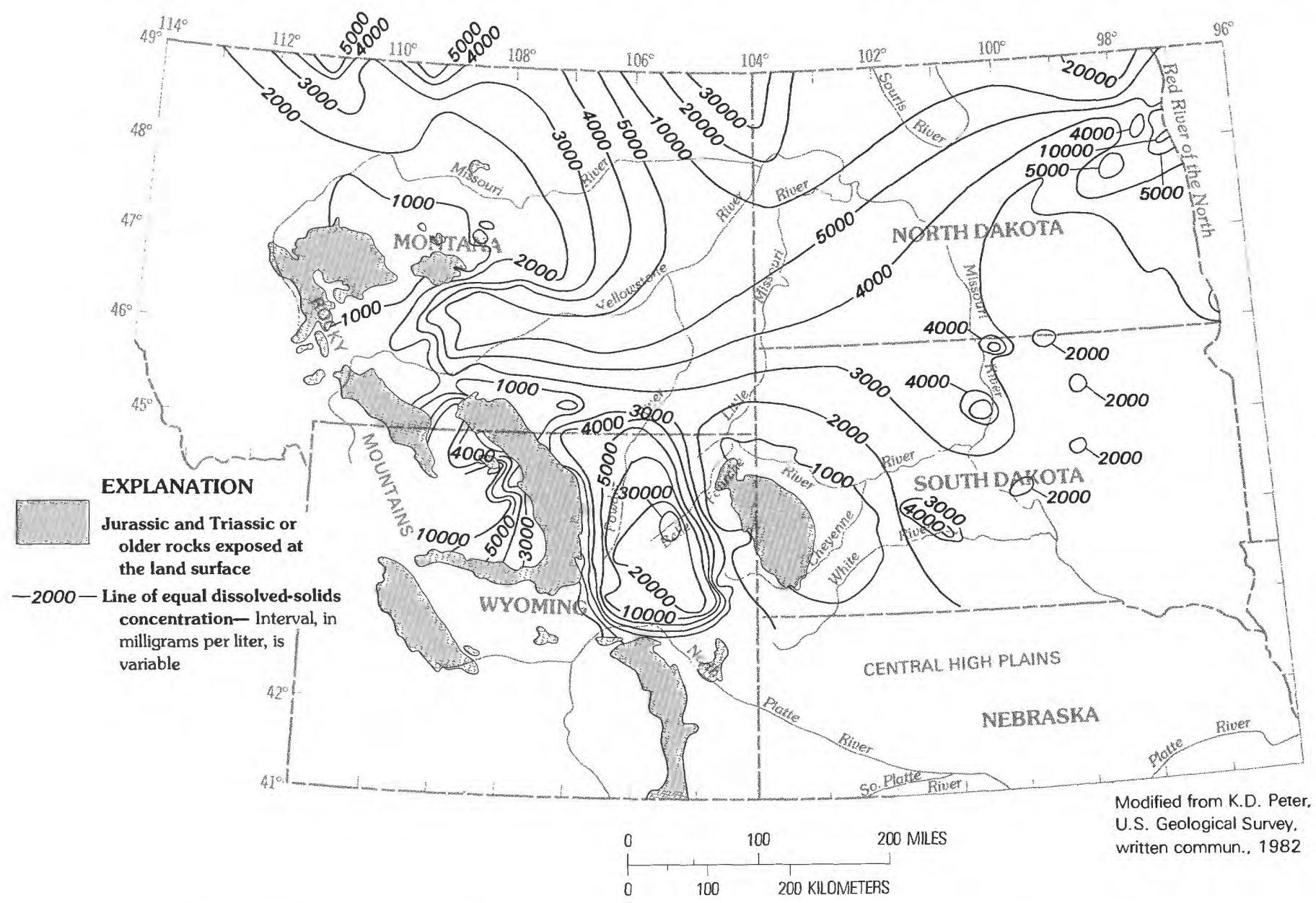

FIGURE 31.-Concentration of dissolved solids in water from the Lower Cretaceous aquifer system.

Devonian system in Wyoming, Montana, southern Saskatchewan, and Alberta: American Association of Petroleum Geologists Bulletin, v. 35 , no. 11 , p. $2368-2408$.

1955 , Mississippian Madison Group stratigraphy and sedimentation in Wyoming and southern Montana: American Association of Petroleum Geologists Bulletin, v. 39, no. 11, p. $2170-2210$.

Anna, L.O., 1986, Geologic framework of the ground-water flow system in Jurassic and Cretaceous rocks in the northern Great Plains in parts of Montana, North Dakota, South Dakota, and Wyoming: U.S. Geological Survey Professional Paper 1402-B, 111 p.

Armstrong, C.A., 1980, Ground-water resources of Dickey and LaMoure Counties, North Dakota: North Dakota State Water Commission County Ground Water Studies 28, Pt. III, 61 p.

Arps, J.J., 1953, The effect of temperature on the density and electrical resistivity of sodium chloride solution: American Institute of Mining, Metallurgical, and Petroleum Engineers Transactions 198 , p. $327-330$.

Asquith, D.O., 1970, Depositional topography and major marine environments, Late Cretaceous, Wyoming: American Association of Petroleum Geologists Bulletin, v. 54, no. 7, p. 1184-1224.

Ataman, Gürol, and Baysal, O., 1978, Clay mineralogy of Turkish borate deposits: Chemical Geology, v. 22, no. 3, p. 233-247.

Averitt, Paul, 1975, Coal resources of the United States, January 1, 1974: U.S. Geological Survey Bulletin 1412, 131 p.
Baars, D.L., 1979, The Colorado plateau aulacogen-Key to continental scale basement rifting, in Podwysocki, M.H., and Earle, J.L., eds., International Conference on Basement Tectonics, 2d, Newark, Del., 1976, Proceedings: Denver, New Basement Tectonics Committee, Inc., p. 157-163.

1981, Pre-Laramine tectonic history of Colorado Plateau [abs.], in Boyd, D.W., ed., Rocky Mountain Foreland basement tectonics: Contributions to Geology, v. 19, no. 2, p. 175.

Back, William, 1966, Hydrochemical facies and ground-water flow patterns in northern part of the Atlantic Coastal Plain: U.S. Geological Survey Professional Paper 498-A, p. A1-A42.

Baillie, A.D., 1950, Devonian geology of Lake Manitoba-Lake Winnipegosis area: Province of Manitoba Department of Mines and Natural Resources Mines Branch Publication 49-2, 72 p.

1955, Devonian system of Williston basin: American Association of Petroleum Geologists Bulletin, v. 39, no. 11, p. 575-629. Baker, D.R., 1962, The Newcastle Formation in Weston County, Wyoming-A non-marine (alluvial) plain deposit: Wyoming Geological Association Annual Field Conference, 17th, 1962, Guidebook, p. 149-162.

Baker, W.J., 1955, Flow in fissured formations: Petroleum Congress, 4th, Rome, 1955, Proceedings, v. 2, p. 379-393.

Ball, J.W., Nordstrom, K.D., and Jenne, E.A., 1980, Additional and revised thermochemical data and computer code for WATEQ2-A computerized chemical model for trace and major element 


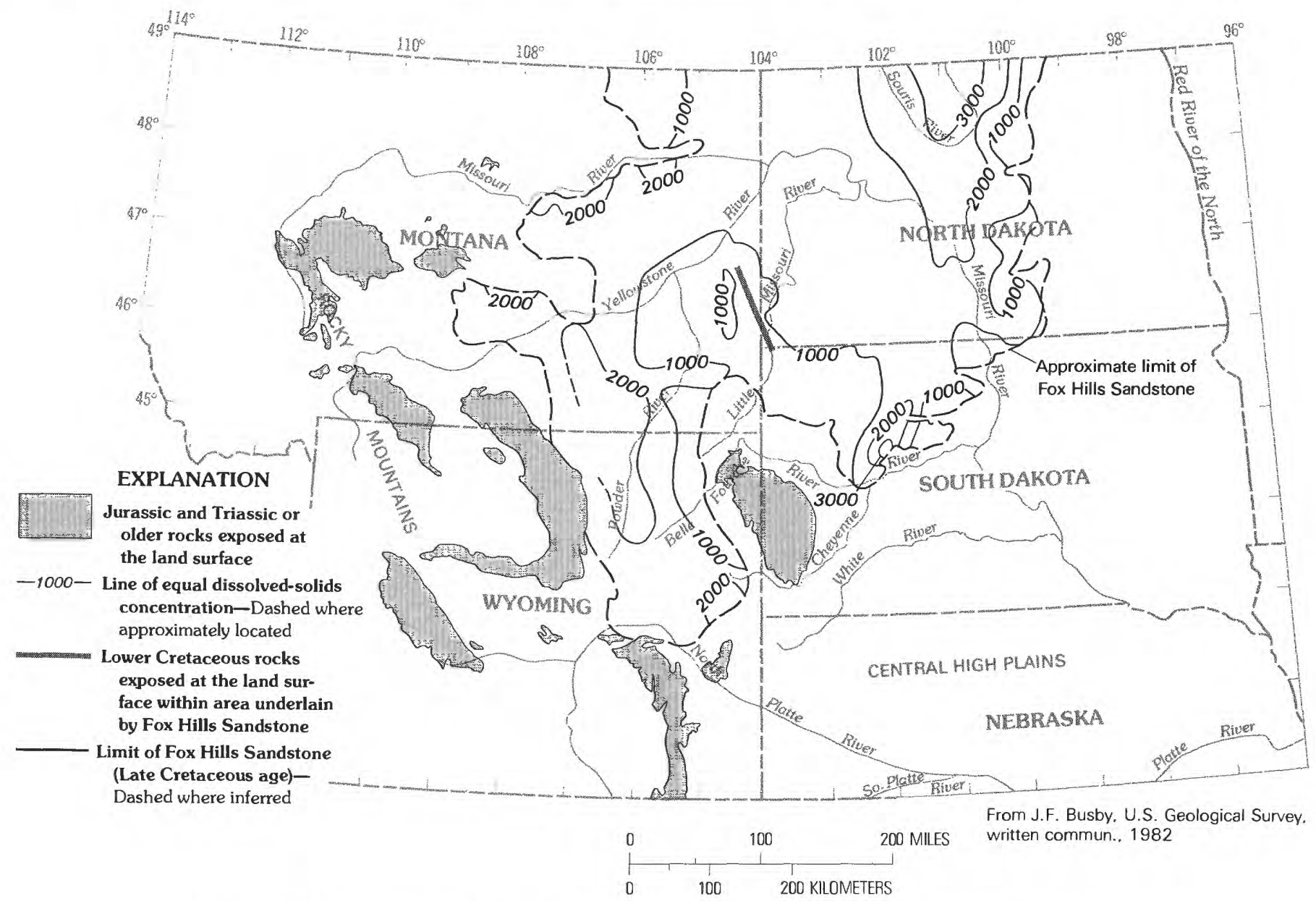

FIGURE 32.-Concentration of dissolved solids in water from the Upper Cretaceous aquifer system.

speciation and mineral equilibria for natural waters: U.S. Geological Survey Water-Resources Investigations 78-116, 114 p.

Ballard, F.V., 1963, Structural and stratigraphic relationships in Paleozoic rocks of eastern North Dakota: North Dakota Geological Survey Bulletin 40, 42 p.

Ballard, W.W., 1969, Red River of northwest Montana and northwest North Dakota: Montana Geological Society Annual Conference, 20th (Eastern Montana Symposium), Billings, Mont., 1969, Proceedings, p. 15-24.

Balster, C.A., 1971, Stratigraphic correlations for Montana and adjacent areas: Montana Bureau of Mines and Geology Special Publication 51, 1 chart.

Barkley, R.C., 1953, Artesian conditions in the area surrounding the Sioux quartzite ridge: South Dakota State Geological Survey Report of Investigations 72, $68 \mathrm{p}$.

Barlow, J.A., Jr., and Haun, J.D., 1966, Regional stratigraphy of Frontier Formation and relation to Salt Creek field, Wyoming: American Association of Petroleum Geologists Bulletin, v. 50, no. 10, p. 2185-2196.

Bates, R.L., 1955, Permo-Pennsylvanian formations between Laramie Mountains, Wyoming, and Black Hills, South Dakota: American Association of Petroleum Geologists Bulletin, v. 39 , no. 11, p. 1979-2002.

Bathurst, R.G.C., 1971, Carbonate sediments and their diagenesis: Amsterdam, Elsevier, 620 p.
Bear, Jacob, 1972, Dynamics of fluids in porous media: New York, Elsevier, 764 p.

Bedinger, M.S., Reed, J.E., and Griffin, J.D., 1973, Digital-computer programs for analysis of ground-water flow: U.S. Geological Survey open-file report, $85 \mathrm{p}$.

Beikman, H.M., 1962, Geology of the Powder River basin, Wyoming and Montana, with reference to subsurface disposal of radioactive wastes: U.S. Geological Survey Trace Elements Investigative Report TEI-823, 85 p.

Berg, R.R., 1968, Point-bar origin of Fall River Sandstone reservoirs, northeastern Wyoming: American Association of Petroleum Geologists Bulletin, v. 52, no. 11, p. 2116-2122.

1976, Trapping mechanisms for oil in Lower Cretaceous Muddy Sandstone at Recluse field, Wyoming: Wyoming Geological Association Annual Field Conference, 28th, 1976, Guidebook, p. 261-272.

Berg, R.R., and Davies, D.K., 1968, Origin of Lower Cretaceous Muddy Sandstone at Bell Creek field, Montana: American Association of Petroleum Geologists Bulletin, v. 52, no. 10, p. 1888-1898.

Berry, F.A.F., and Hanshaw, B.B. 1960, Geologic field evidence suggesting membrane properties of shales [abs.]: International Geological Congress, 21st, Copenhagen, 1960, Proceedings, p. 209.

Billings, G.K., Hitchon, Brian, and Shaw, D.R., 1969, Geochemistry and origin of formation waters in the western Canada sedimentary 


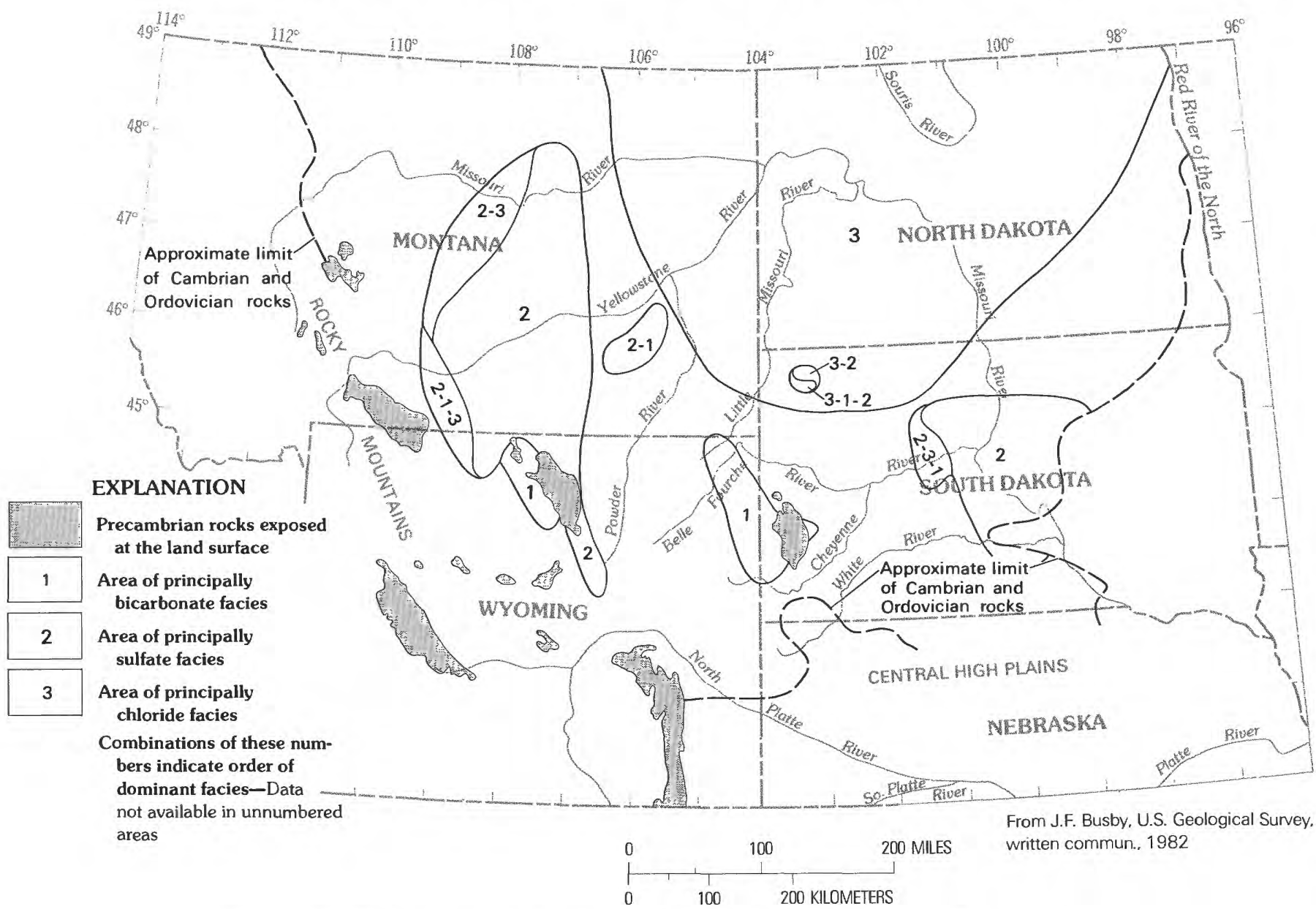

Figure 33.-Hydrochemical facies of water in the Cambrian-Ordovician aquifer system.

basin-2. Alkali metals, in Geochemistry of subsurface brines: Chemical Geology, v. 4, nos. 1-2, p. 211-223.

Bishop, M.S., 1960, Subsurface mapping: New York, John Wiley, $198 \mathrm{p}$.

Bjorle, P.F., and Anderson, S.B., 1978, Stratigraphy and depositional setting of the Carrington Shale facies (Mississippian) of the Williston basin: Montana Geological Society Annual Conference, 24th (Williston Basin Symposium), Billings, Mont., 1978, Guidebook, p. 165-176.

Blackstone, D.L., Jr., 1949, Structural pattern of the Powder River basin (Wyoming): Wyoming Geological Association Annual Field Conference, 4th, 1949, Guidebook, p. 35-36.

1971, Plate tectonics and its possible role in the Rocky Mountains: Wyoming Geological Association Annual Field Conference, 23d, 1971, Guidebook, p. 11-17.

1981 , Compression as an agent in deformation of the east-central flank of the Bighorn Mountains, Sheridan and Johnson Counties, Wyoming, in Boyd, D.W., ed., Rocky Mountain Foreland basement tectonics: Contributions to Geology, v. 19, no. 2, p. 105-122.

Blankennagel, R.K., Howells, L.W., and Miller, W.R., 1981, Completion and testing of Madison Limestone test well 3, NW1/4 SE1/4 sec. 35, T. 2 N., R. 27 E., Yellowstone County, Montana: U.S. Geological Survey Open-File Report 81-528, 91 p.

Blankennagel, R.K., Howells, L.W., Miller, W.R., and Hansen, C.V. 1979, Preliminary data for Madison Limestone test well 3,
NW1/4SE1/4 sec. 35 , T. 2 N., R. 27 E., Yellowstone County, Montana: U.S. Geological Survey Open-File Report 79-745, 201 p. Blankennagel, R.K., Miller, W.R., Brown, D.L., and Cushing, E.M., 1977, Report on preliminary data for Madison Limestone test well 1, NE $1 / 4 \mathrm{SE}^{1 / 4}$ sec. 15, T. 57 N., R. 65 W., Crook County, Wyoming: U.S. Geological Survey Open-File Report 77-164, 110 p.

Blatt, Harvey, Middleton, Gerard, and Murray, Raymond, 1972, Origin of sedimentary rocks: Englewood Cliffs, N.J., Prentice Hall, $634 \mathrm{p}$.

Boggs, J.M., and Jenkins, A.M., 1980, Analysis of aquifer tests conducted at the proposed Burdock Uranium Mine Site, Burdock, South Dakota: Tennessee Valley Authority, Office of Natural Resources, Division of Water Resources, Water System Development Branch Report WR28-1-520-109, 73 p.

Bolyard, D.W., and McGregor, A.A., 1966, Stratigraphy and petroleum potential of Lower Cretaceous Inyan Kara Group in northeastern Wyoming, southeastern Montana, and western South Dakota: American Association of Petroleum Geologists Bulletin, v. 50 , no. 10 , p. 2221-2244.

Boner, F.C., Lines, G.C., Lowry, M.E., and Powell, J.E., 1975, Geohydrologic reconnaissance and measurement of perennial streams crossing outcrops of Madison Limestone, northeastern Wyoming, 1974: U.S. Geological Survey Open-File Report 75-614, 98 p.

Bouska, V., and Pesek, J., 1976, The geochemical role of boron in the 


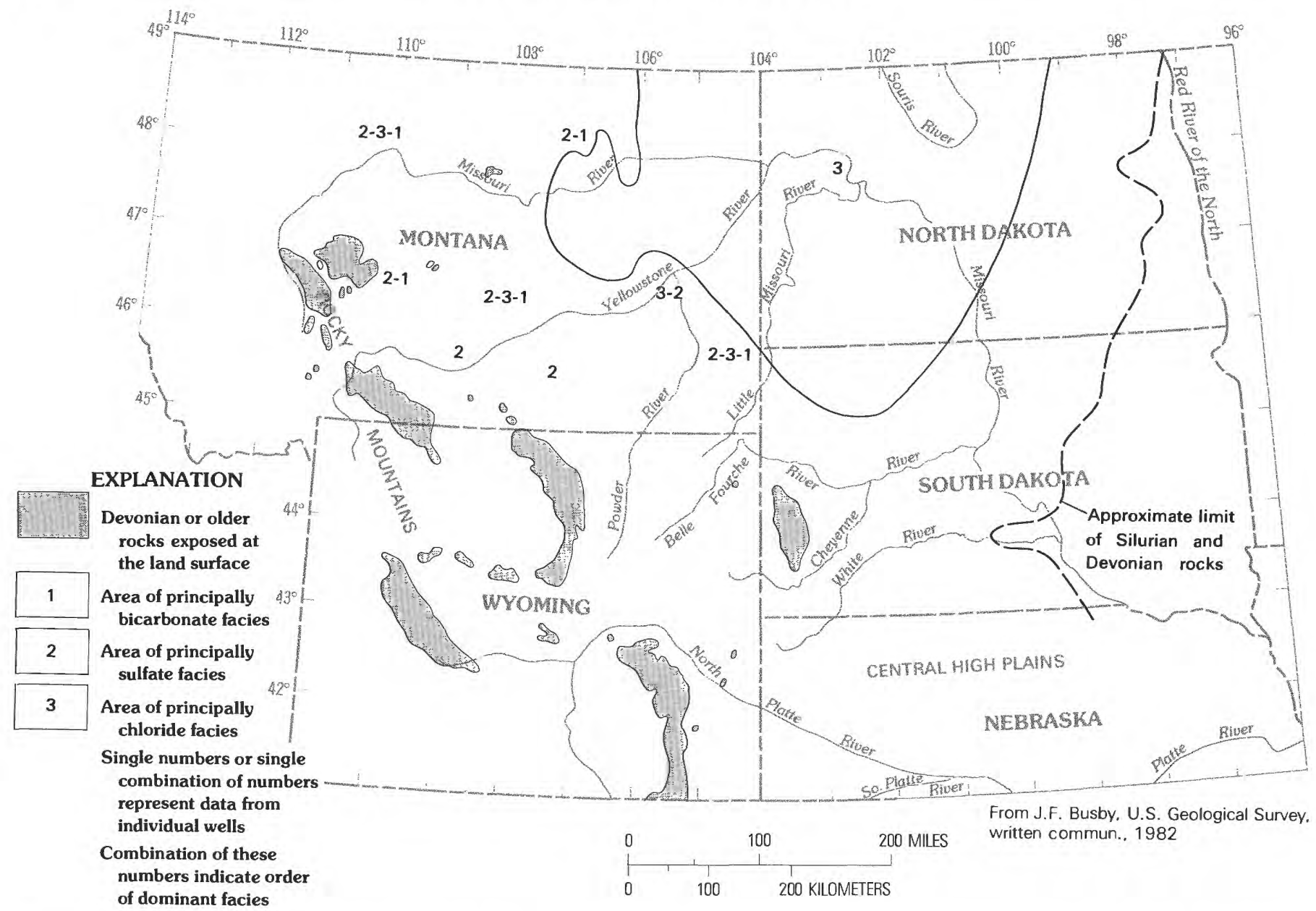

FIGURE 34.-Hydrochemical facies of water in the Silurian and Devonian rocks (a major confining system or unit overlying the CambrianOrdovician aquifer system).

Carboniferous sediments of Czechoslovakia, in Konta, Jiri, ed., Conference on Clay Mineralogy and Petrology, 7th, Karlovy Vary, Bohemia, 1976, Proceedings: Karlovy Vary, Bohemia, Univerzita Karlova Praha, p. 203-209.

Branch, J.L., 1976, Paleogeomorphology of Fred and George Creek area, Toole County, Montana: American Association of Petroleum Geologists Bulletin, v. 60 , no. 8, p. 1391.

Bredehoeft, J.D., 1973, Mass transport in flowing ground water: Water Resources Research, v. 9, no. 1, p. 194-210.

Bredehoeft, J.D., Back, William, and Hanshaw, B.B., 1982, Regional ground-water flow concepts in the United States-Historical perspective, in Narasimhan, T.N., ed., Recent trends in hydrology: Geological Society of America Special Paper 189, p. 297-316.

Bredehoeft, J.D., Counts, H.B., Robson, S.G., and Robertson, J.B., 1976, Solute transport in groundwater systems, in Rodda, J.C., ed., Facets of hydrology: New York. John Wiley, 229 p.

Bredehoeft, J.D., and Hanshaw, B.B., 1968, On the maintenance of anomalous fluid pressures-Part 1 , Thick sedimentary sequences: Geological Society of America Bulletin, v. 79, no. 9, p. 1097-1106.

Bredehoeft, J.D., Neuzil, C.E., and Milly, P.C.D., 1983, Regional flow in the Dakota aquifer-A study of the role of confining layers: U.S. Geological Survey Water-Supply Paper 2237, 45 p.

Bredehoeft, J.D., and Pinder, G.F., 1970, Digital analysis of areal flow in multiaquifer groundwater systems-A quasi-three-dimensional model: Water Resources Research, v. 6, no. 3, p. 883-888.

Brenner, R.L., 1976, Contrasting sedimentary styles in an epicontinental seaway-Cretaceous sandstones of the Powder River basin: Geological Society of America Abstracts with Programs, v. 8, no. 6, p. 789-790.

Brock, B.B., 1972, A global approach to geology: Cape Town, South Africa, A.A. Belkema, 365 p.

Brown, C.B., 1944, Report on an investigation of water losses in streams flowing east out of the Black Hills, South Dakota: U.S. Department of Agriculture Soil Conservation Service Special Report 8, $45 \mathrm{p}$.

Brown, D.L., 1978, Wrench-style deformational patterns associated with a meridional stress axis recognized in Paleozoic rocks in parts of Montana, South Dakota, and Wyoming: Montana Geological Society Annual Conference, 24th (Williston Basin Symposium), Billings, Mont., 1978, Guidebook, p. 17-31.

Brown, D.L., Blankennagel, R.K., Busby, J.F., and Lee, R.W., 1977, Preliminary data for Madison Limestone test well 2, SE1/4 SE $1 / 4$ sec. 18, T. 1 N., R. 54 E., Custer County, Montana: U.S. Geological Survey Open-File Report 77-863, 135 p.

Brown, D.L., Blankennagel, R.K., MacCary, L.M., and Peterson, J.A., 1982, Correlation of paleostructure and sediment deposition in 


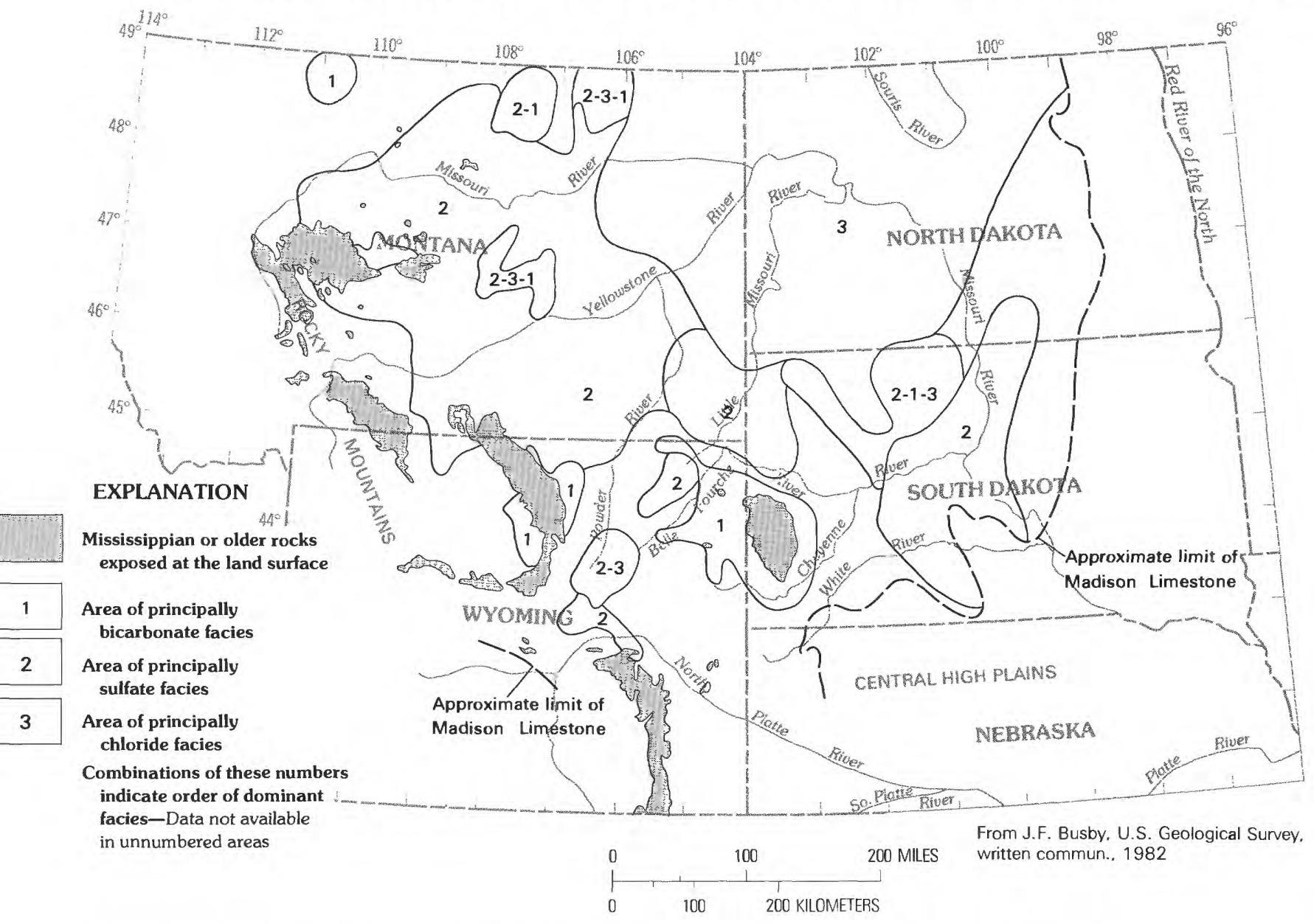

FIGURE 35.-Hydrochemical facies of water in the Mississippian aquifer system, including the Madison Limestone.

the Madison Limestone and associated rocks in parts of Montana, North Dakota, South Dakota, Wyoming, and Nebraska: U.S. Geological Survey Open-File Report 82-906, 80 p.

Brown, Eugene, Skougstad, M.W., and Fishman, M.J., 1970, Methods for collection and analysis of water samples for dissolved minerals and gases: U.S. Geological Survey Techniques of Water-Resources Investigations, bk. 5, chap. $\mathrm{C} 1,160 \mathrm{p}$.

Brown, P.M., Miller, J.A., and Swain, F.M., 1972, Structural and stratigraphic framework and spatial distribution of permeability of the Atlantic Coastal Plain, North Carolina to New York: U.S. Geological Survey Professional Paper 796, $79 \mathrm{p}$.

Brown, R.W., 1958, Fort Union Formation in the Powder River basin, Wyoming: Wyoming Geological Association Annual Field Conference, 13th, 1958, Guidebook, p. 111-113.

1962, Paleocene flora of the Rocky Mountains and Great Plains: U.S. Geological Survey Professional Paper 375, 119 p.

Brown, W.G., 1981, Surface and subsurface examples from the Wyoming Foreland as evidences of a regional compressional origin for the Laramide orogeny [abs.], in Boyd, D.W., ed., Rocky Mountain Foreland basement tectonics: Contributions to Geology, v. 19 , no. 2 , p. $175-177$.

Bryson, R.A., Baerreis, D.A., and Wendland, W.M., 1970, The character of late-glacial and postglacial climatic changes in Pleistocene and recent environments of the Central Great Plains: Lawrence,
Kans., University of Kansas, Department of Geology Special Publication 3, p. 53-74.

Burchfiel, B.C., and Davis, G.A., 1975, Nature and controls of Cordilleran orogenesis, western U.S.-Extensions of an earlier synthesis: American Journal of Science, v. 275-A, p. 363-396.

Busby, J.F., Lee, R.W., and Hanshaw, B.B., 1983, Major geochemical processes related to the hydrology of the Madison aquifer system and associated rocks in parts of Montana, South Dakota, and Wyoming: U.S. Geological Survey Water-Resources Investigations Report 83-4093, 180 p.

Byers, C.W., and Larson, D.W., 1979, Paleoenvironments of Mowry Shale (Lower Cretaceous), western and central Wyoming: American Association of Petroleum Geologists Bulletin, v. 63, no. 3, p. 354-375.

Campbell, C.V., 1967, Lamina, laminaset, bed, and bedset: Sedimentology, v. 8 , no. 1 , p. $7-26$.

1976, Reservoir geometry of a fluvial sheet sandstone: American Association of Petroleum Geologists Bulletin, v. 60, no. 7, p. 1009-1020.

Campbell, C.V., and Oaks, R.O., Jr., 1973, Estuarine sandstone filling tidal scours, Lower Cretaceous Fall River Formation, Wyoming: Journal of Sedimentary Petrology, v. 43, no. 3, p. 765-778.

Carlson, C.G., and Anderson, S.B., 1960, Stratigraphy of the Winnipeg and Deadwood Formations in North Dakota: North Dakota Geological Survey Bulletin 35, 149 p. 


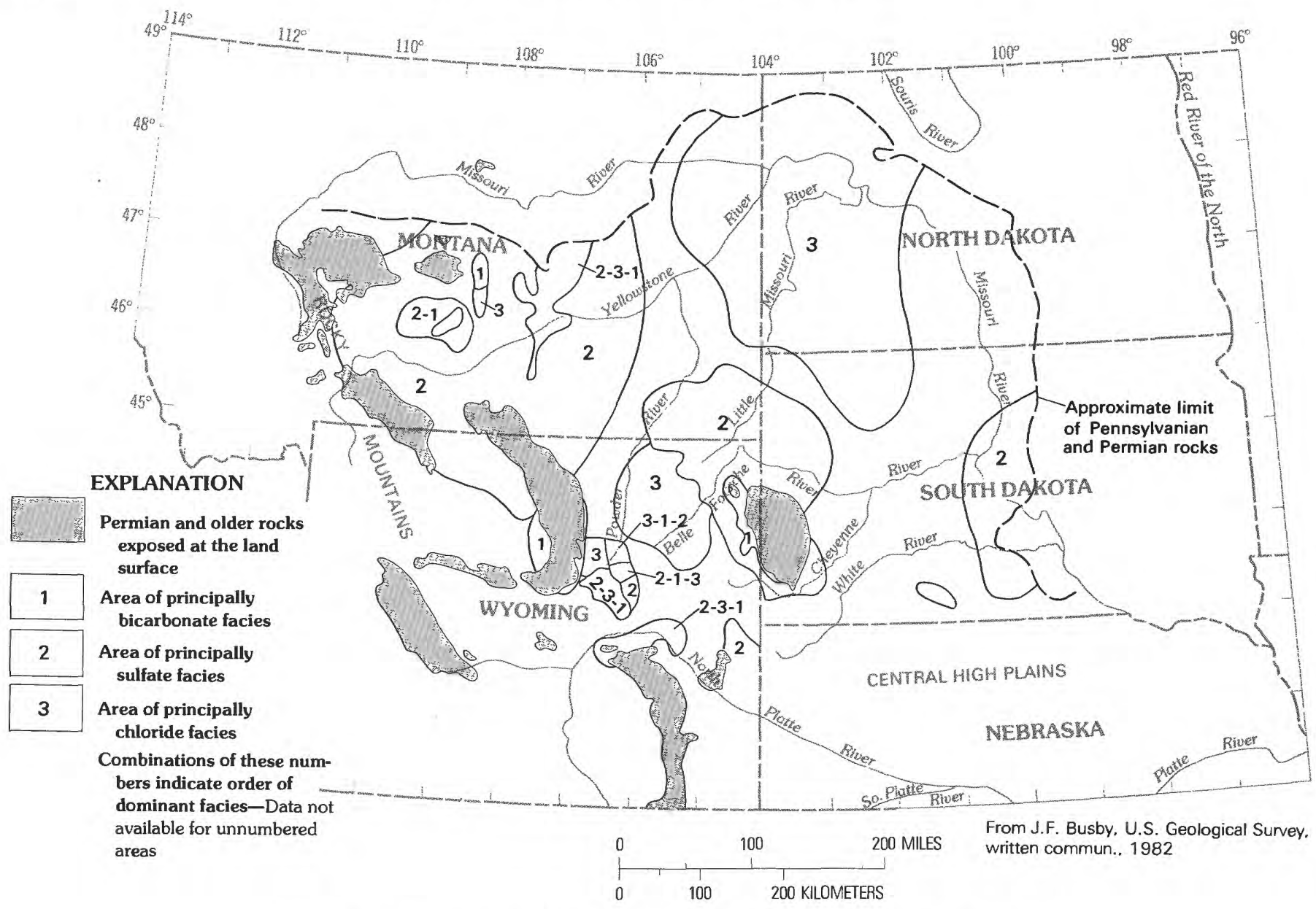

Figure 36.-Hydrochemical facies of water in the Pennsylvanian aquifer system.

1965, Sedimentary and tectonic history of North Dakota part of Williston basin: American Association of Petroleum Geologists Bulletin, v. 49, no. 11, p. 1833-1846.

Carlson, C.G., Bakken, W.E., and Kume, J.B., 1960, Subsurface geology and development of petroleum in North Dakota: North Dakota Geological Survey Bulletin 34, 20 p.

Carlson, C.G., and Eastwood, W.P., 1962, Upper Ordovician and Silurian rocks of North Dakota: North Dakota Geological Survey Bulletin 38, 52 p.

Carpenter, A.B., and Miller, J.C., 1969, Geochemistry of saline subsurface water, Saline County, Missouri, in Geochemistry of subsurface brines: Chemical Geology, v. 4, nos. 1-2, p. 135-167.

Carroll, W.K., 1978, Depositional and paragenetic controls on porosity development, upper Red River Formation, North Dakota: Montana Geological Society Annual Conference, 24th (Williston Basin Symposium), Billings, Mont., 1978, Guidebook, p. 79-94.

Cary, S.W., 1958, A tectonic approach to continental drift, in Cary, S.W., ed., Continental drift: Hobart, Tasmania, Australia, Tasmania University, p. 177-355.

Chamberlin, R.T., 1945, Basement control in Rocky Mountain deformation: American Journal of Science, v. 243-A, p. 98-116.

Chapman, R.E., 1982, Effects of oil and gas accumulation on water movement: American Association of Petroleum Geologists Bulletin, v. 66 , no. 3 , p. $368-378$.

Chilingar, G.V., Mannon, R.W., and Rieke, H.H., III, eds., 1972, Oil and gas production from carbonate rocks: New York, Elsevier, $408 \mathrm{p}$.

Chilingar, G.V., and Rieke, H.H., III, 1969, Some chemical alterations of subsurface waters during diagenesis, in Geochemistry of subsurface brines: Chemical Geology, v. 4, nos. 1-2, p. 235-252.

Chisholm, W.A., 1970, Depositional history and petrography of two Fall River Formation sandstone reservoirs in the eastern Powder River basin and their relationship to oil entrapment: Wyoming Geological Association Annual Field Conference, 22d, 1970, Guidebook, p. 169-185.

Choquette, P.W., and Pray, L.C., 1970, Geologic nomenclature and classification of porosity in sedimentary carbonates: American Association of Petroleum Geologists Bulletin, v. 54, no. 2, p. 207-250.

Christensen, C.M., 1967, Geology and water resources of Clay County, South Dakota-Part 1, Geology: South Dakota State Geological Survey Bulletin 19, 86 p.

Clarke, F.C., 1924, Data of geochemistry (5th ed.): U.S. Geological Survey Bulletin 770, $841 \mathrm{p}$.

Clayton, Lee, Carlson, C.G., Moore, W.L., Greenewold, Gerald, Holland, F.D., Jr., and Moran, S.R., 1977, The Slope (Paleocene) and Bullion Creek (Paleocene) Formations of North Dakota: North Dakota Geological Survey Report of Investigation no. 59, $14 \mathrm{p}$.

Clement, J.H., 1976, Geologic history key to accumulation at Cedar 


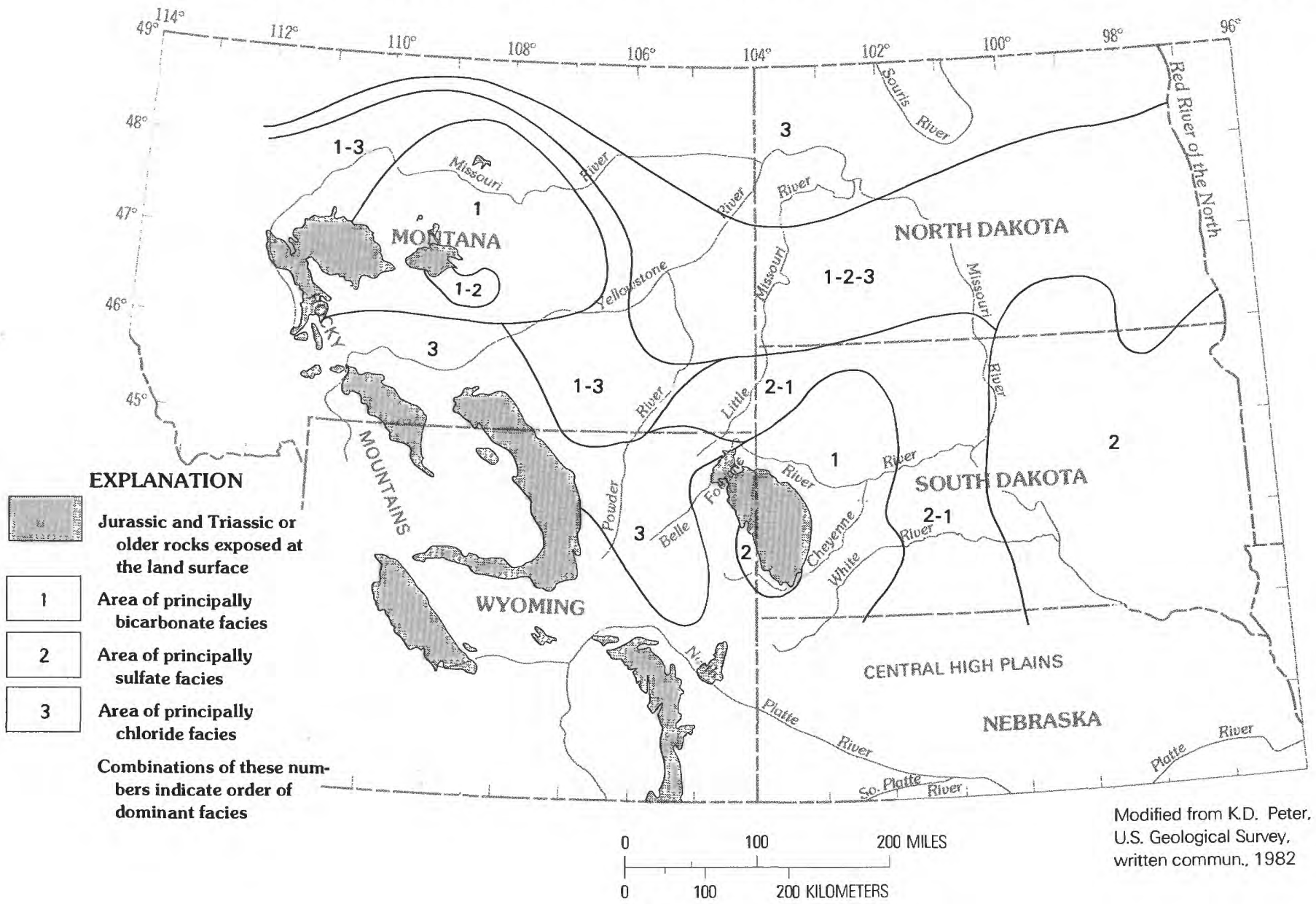

Figure 37.-Hydrochemical facies of water in the Lower Cretaceous aquifer system.

Creek: American Association of Petroleum Geologists Bulletin, v. 60 , no. 11 , p. $2067-2068$.

Cloos, Hans, 1948, The ancient European basement blocksPreliminary note: Transactions of the American Geophysical Union, v. 29, no. 1 , p. 99-103.

Cluff, R.M., 1976, Paleoecology and depositional environments of the Mowry Shale (Albian), Black Hills region: Madison, Wis., University of Wisconsin M.S. thesis, 104 p.

Cobban, W.A., 1945, Marine Jurassic formations of Sweetgrass arch, Montana: American Association of Petroleum Geologists Bulletin, v. 29 , no. 9 , p. $1262-1303$.

Coffin, D.L., Reed, T.E., and Ayers, S.D., 1977, Water-level changes in wells along the west side of the Cedar Creek anticline, southeastern Montana: U.S. Geological Survey Water-Resources Investigations 77-93, $11 \mathrm{p}$.

Cole, L.H., 1915, The salt deposits of Canada and the salt industry: Canadian Department of Energy, Mines and Resources, Mines Branch Report 325, $152 \mathrm{p}$.

Collins, A.G., 1975, Geochemistry of oil field waters: New York, Elsevier, 496 p.

Coney, P.J., 1975, Overview of Late Cretaceous through Cenozoic Cordilleran plate tectonics: Geological Society of America Abstracts with Programs, v. 7, no. 7, p. 1035

Conybeare, C.E.B., 1979, Lithostratigraphic analysis of sedimentary basins: Canberra, Australia, Australian National University Academic Press, 555 p.
Cooley, M.E., 1982, Distribution of relative fracture (and secondary) permeability in the sedimentary rocks, northern Great PlainsRocky Mountain region of Montana, Wyoming, North Dakota, South Dakota, and northern Nebraska: Cheyenne, Wyo., unpublished U.S. Geological Survey open-file map, 1 sheet.

Cooley, R.L., 1977, A method of estimating parameters and assessing reliability for models of steady state groundwater flow-1, Theory and numerical properties: Water Resources Research, v. 13 , no. 2 , p. $318-324$.

Cotter, E.J., 1965, Waulsortian-type carbonate banks in the Mississippian Lodgepole Formation of central Montana: Journal of Geology, v. 73 , no. 6 , p. $881-888$.

Craig, L.C., 1972, Mississippian system, in Geologic atlas of the Rocky Mountain region: Denver, Rocky Mountain Association of Geologists, p. 100-110.

Crandell, D.R., 1958, Geology of the Pierre area, South Dakota: U.S. Geological Survey Professional Paper 307, 83 p.

Crawford, J.C., 1942, Oil-field waters of Montana plains: American Association of Petroleum Geologists Bulletin, v. 26, no. 8, p. 1317-1374.

Crist, M.A., 1977, Hydrologic evaluation of the Arikaree Formation near Lusk, Niobrara, and Goshen Counties, Wyoming: U.S. Geological Survey Water-Resources Investigations 77-111, 23 p.

Croft, M.G., 1971, A method of calculating permeability from electric logs, in Geological Survey research 1971: U.S. Geological Survey Professional Paper 750-B, p. B265-B269. 


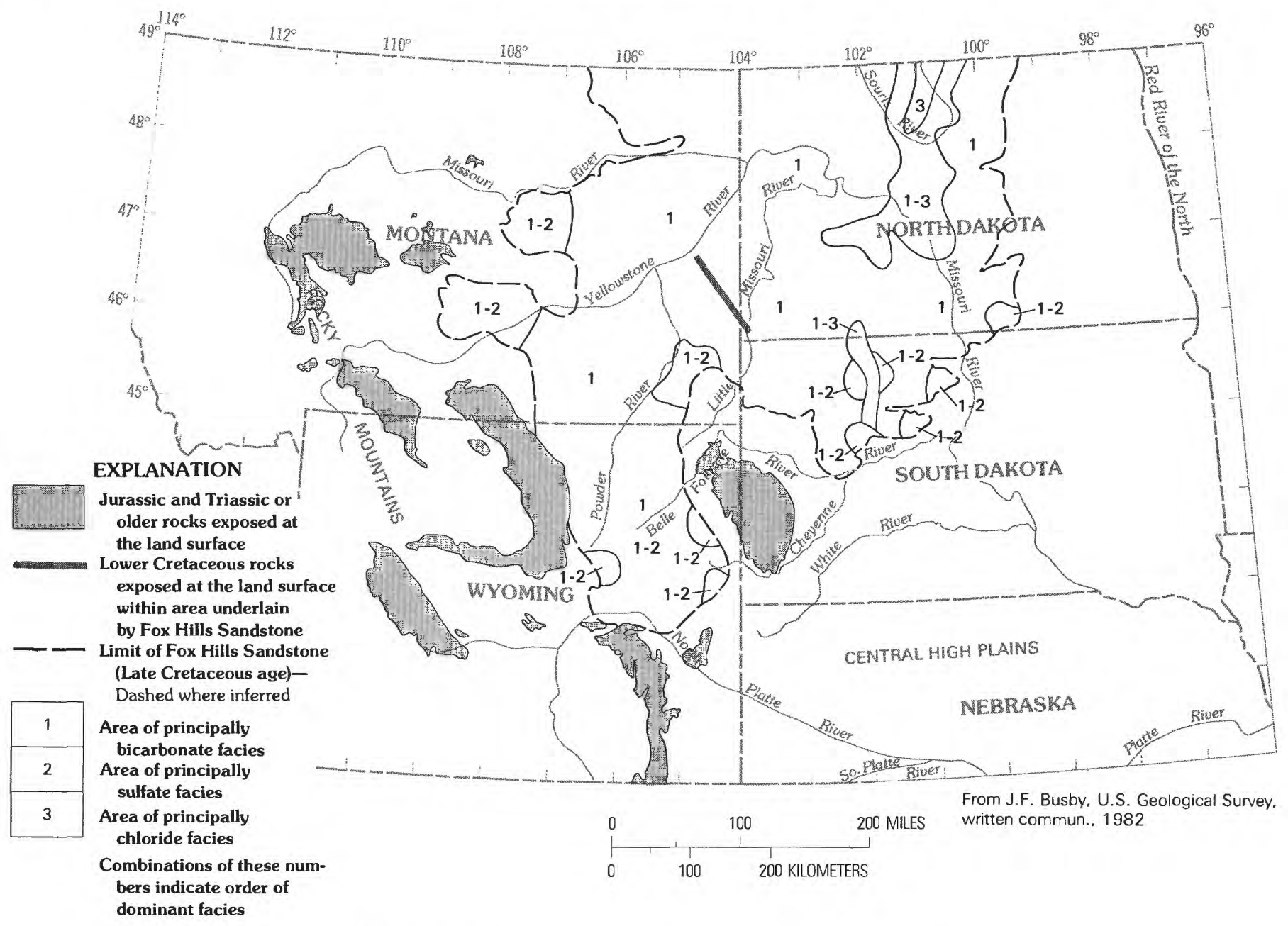

FiguRE 38.-Hydrochemical facies of water in the Upper Cretaceous aquifer system.

Crowley, A.J., 1951, Possible Lower Cretaceous uplifting of Black Hills, Wyoming and South Dakota: American Association of Petroleum Geologists Bulletin, v. 35, no. 1, p. 83-107.

Curry, W.H., III, 1962, Depositional environments in central Wyoming during the Early Cretaceous: Wyoming Geological Association Annual Field Conference, 17th, 1962, Guidebook, p. 118-122.

1971, Laramide structural history of the Powder River basin, Wyoming: Wyoming Geological Association Annual Field Conference, 23d, 1971, Guidebook, p. 49-60.

Cushing, E.M., 1977a, Description of the Madison aquifer study, Montana, North Dakota, South Dakota, and Wyoming: U.S. Geological Survey Open-File Report 77-514, 10 p.

$1977 \mathrm{~b}$, The Madison aquifer study-Current status: U.S Geological Survey Open-File Report 77-692, 18 p.

Cvancara, A.M., 1976a, Geology of the Fox Hills Formation (Late Cretaceous) in the Williston basin of North Dakota, with reference to uranium potential: North Dakota Geological Survey Report of Investigation no. $55,16 \mathrm{p}$.

1976b, Geology of the Cannonball Formation (Paleocene) in the Williston basin, with reference to uranium potential: North Dakota Geological Survey Report of Investigation no. 57, 22 p.

Dahl, A.R., and Hagmaier, J.L., 1976, Genesis and characteristics of the southern Powder River basin uranium deposits, Wyoming:
Wyoming Geological Association Annual Field Conference, 28th, 1976, Guidebook, p. 243-252.

Dana, J.D., 1895, Manual of geology (4th ed.): New York, American Book Company, 1,087 p.

Darcy, Henri, 1856, Les fontaines publiques de la ville de Dijon [The water supply of Dijon]: Paris, Victor Dolmont, $647 \mathrm{p}$.

Darton, N.H., 1896, Preliminary report on artesian waters of a portion of the Dakotas: U.S. Geological Survey 17th Annual Report, Part II, p. 603-694.

1901, Preliminary description of the geology and water resources of the southern half of the Black Hills and adjoining regions in South Dakota and Wyoming: U.S. Geological Survey 21st Annual Report, Part IV, p. 489-599.

1905 , Preliminary report on the geology and underground water resources of the central Great Plains: U.S. Geological Survey Professional Paper 32, 433 p.

1909, Geology and underground waters of South Dakota: U.S. Geological Survey Water-Supply Paper 227, 156 p.

1918, Artesian waters in the vicinity of the Black Hills, South Dakota: U.S. Geological Survey Water-Supply Paper 428, 64 p. Darton, N.H., compiler, 1951, Geologic map of South Dakota: U.S. Geological Survey, scale 1:500,000.

Davis, G.R., 1979, Dolomite reservoir rocks-Processes, controls, 


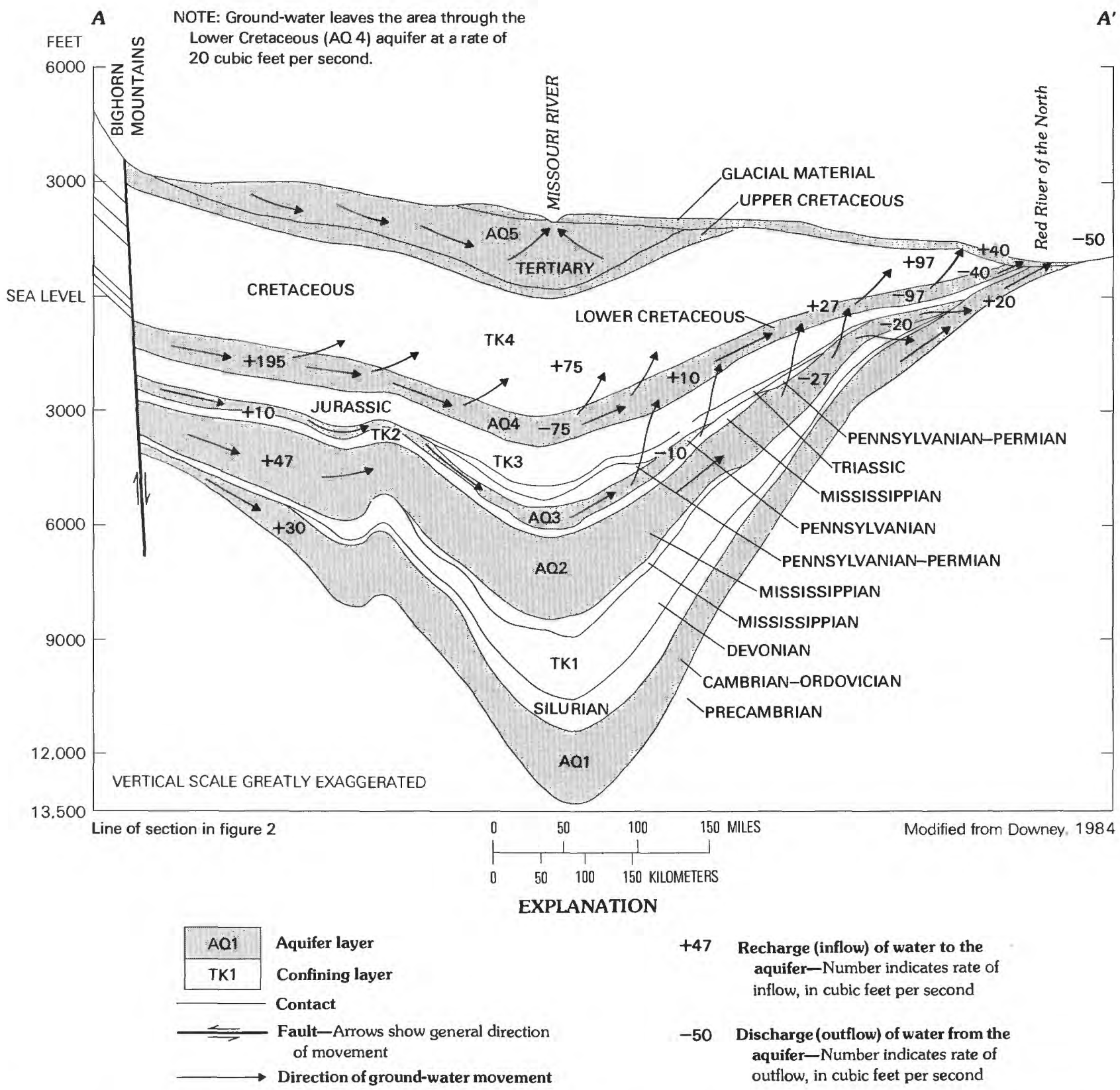

FIGURE 39.-Generalized geohydrologic section showing simulated rates of ground-water recharge, flow, leakage, and discharge from a ground-water recharge area in Montana to a discharge area in North Dakota.

porosity development, in Moore, C.H., Jr., organizer, Geology of carbonate porosity: American Association of Petroleum Geologists Continuing Education Course Note Series 11, p. C1-C17.

Davis, J.C., 1970, Petrology of Cretaceous Mowry Shale of Wyoming: American Association of Petroleum Geologists Bulletin, v. 54, no. 3 , p. 487-502.

1973, Statistics and data analysis in geology: New York, John Wiley, $54 \mathrm{p}$.

Davis, R.W., Dyer, C.F., and Powell, J.E., 1961, Progress report on wells penetrating artesian aquifers in South Dakota: U.S. Geological Survey Water-Supply Paper 1534, 100 p.

Davis, S.N., 1969, Porosity and permeability of natural materials, in
DeWeist, R.J.M., ed., Flow-through porous media: New York, Academic Press, p. 53-59.

Davis, S.N., and Roger, S.M., 1966, Hydrogeology: New York, John Wiley, $463 \mathrm{p}$.

Degen, E.T., 1965, Geochemistry of sediments-A brief survey: Englewood Cliffs, N.J., Prentice Hall, 342 p.

DeGraw, H.M., 1969, Subsurface relations of the Cretaceous and Tertiary: Nebraska Geological Survey Open-File Report, 137 p.

1975, The Pierre-Niobrara unconformity in western Nebraska, in Caldwell, W.G.E., ed., The Cretaceous system in the Western Interior of North America: Geological Association of Canada Special Paper 13, p. 589-606. 


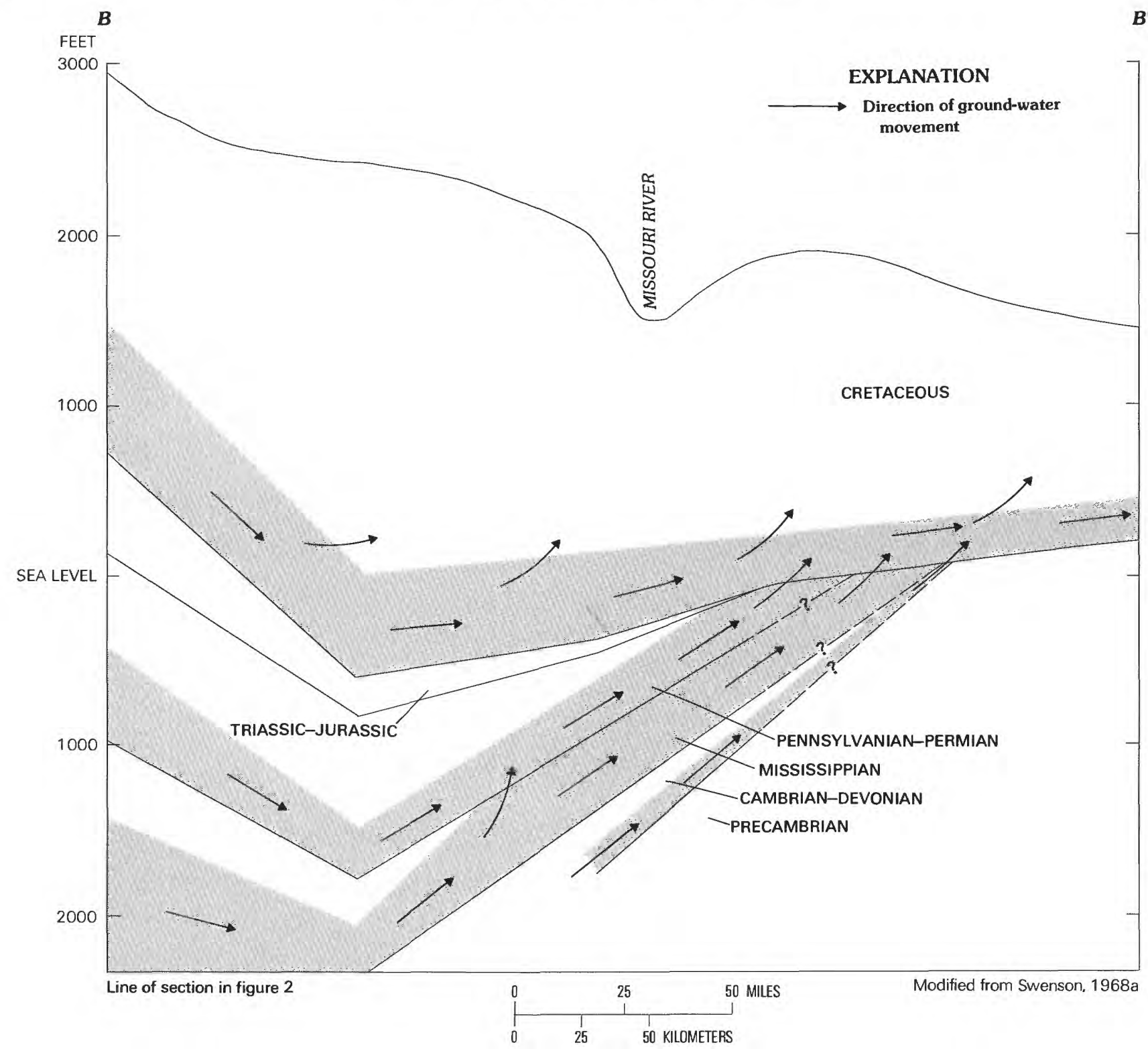

FIGURE 40.-Generalized geohydrologic section showing ground-water discharge from the aquifer systems consisting of rocks of Paleozoic age to the aquifer systems consisting rocks of Mesozoic age in central South Dakota.

Deike, R.G., 1978, Permeability development in Ordovician and Mississippian dolomites, Wyoming and Montana [abs.]: Montana Geological Society Annual Conference, 24th (Williston Basin Symposium), Billings, Mont., 1978, Guidebook, p. 189.

DeMille, G., Shouldice, J.R., and Nelson, H.W., 1964, Collapse structures related to evaporites of the Prairie Formation, Saskatchewan: Geological Society of America Bulletin, v. 75, no. 4, p. 307-316.

Denson, N.M., and Chisholm, W.A., 1971, Summary of mineralogic and lithologic characteristics of Tertiary sedimentary rocks in the middle Rocky Mountains and the northern Great Plains, in Geological Survey research 1971: U.S. Geological Survey Professional Paper 750-C, p. C117-C126.

Denson, N.M., and Gill, J.R., 1965a, Uranium-bearing lignite and carbonaceous shale in the southwestern part of the Williston basin-A regional study: U.S. Geological Survey Professional Paper 463, $75 \mathrm{p}$.

$1965 \mathrm{~b}$, Chemical, semiquantitative, spectrographic heavymineral analyses of rocks and water samples and a table of selected dry holes and producing wells from the Williston basin: U.S. Geological Survey open-file report, 28 tables.

Denson, N.M., and Horn, G.H., 1975, Geologic and structure map of the southern part of the Powder River basin, Converse, Niobrara, and Natrona Counties, Wyoming: U.S. Geological Survey Miscellaneous Investigations Series Map I-877, scale 1:125,000, 2 sheets.

Desaulniers, D.E., Cherry, J.A., and Fritz, Peter, 1982, Origin, age, and movement of pore water in clayey Pleistocene deposits in south central Canada, in Perry, E.C., Jr., ed., Isotope studies of 


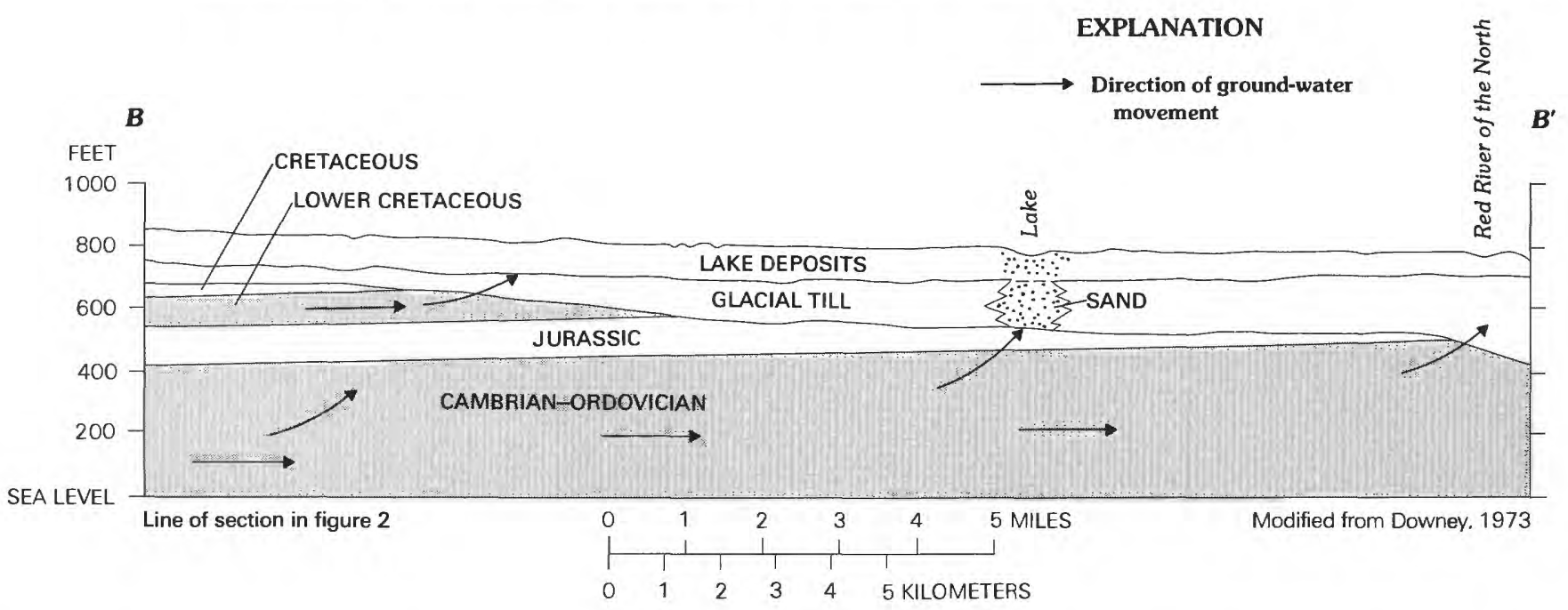

FIGURE 41.-Generalized geohydrologic section showing ground-water movement in the Cambrian-Ordovician aquifer system in northeastern North Dakota.

hydrologic processes-Selected papers from a symposium: DeKalb, Ill., Northern Illinois University Press, p. 45-55.

DeWild, Grant, 1980, Groundwater investigations, Worthing Well \#1, South Lincoln rural water system: Sioux Falls, S. Dak., Reckert and Associates Co., $86 \mathrm{p}$.

Dickinson, W.R., 1974, Plate tectonics and sedimentation, in Tectonics and sedimentation: Society of Economic Paleontologists and Mineralogists Special Publication 22, p. 1-27.

Diment, W.H., Urban, T.C., Sass, J.H., Marshall, B.V., Munroe, R.J., and Lachenbruch, A.H., 1975, Temperatures and heat contents based on conductive transport of heat, in White, D.F., and Williams, D.L., eds., Assessment of geothermal resources of the United States-1975: U.S. Geological Survey Circular 726, p. 84-103.

Dingman, R.J., and Angino, E.E., 1969, Chemical composition of selected brines as an aid to interpreting change in water chemistry with depth, in Geochemistry of subsurface brines: Chemical Geology, v. 4, nos. 1-2, p. 325-339.

Dinwiddie, G.A., and others, 1979, Plan of study for the northern Great Plains regional aquifer system analysis in parts of Montana, North Dakota, South Dakota, and Wyoming: U.S. Geological Survey Water-Resources Investigations 79-34, $24 \mathrm{p}$.

Dobbin, C.E., and Erdmann, C.E., 1955, Structure contour map of the Montana plains: U.S. Geological Survey Oil and Gas Investigations Map OM-178B, scale 1:1,000,000.

Dodge, K.A., and Levings, G.W., 1980, Measurements of discharge, gain or loss in flow, and chemical quality of the Poplar and Redwater Rivers, northwestern Montana, October 24-25, 1979: U.S. Geological Survey Open- File Report 80-1210, 16 p.

Domenico, P.A., and Mifflin, M.D., 1965, Water from low-permeability sediments and land subsidence: Water Resources Research, v. 1, no. 4 , p. $563-576$.

Downey, J.S., 1969, Geology of northeastern North Dakota, Pederson, D.T., and Reid, J.R., eds: North Dakota Geological Survey Miscellaneous Series 39, p. 12.

1971, Ground-water resources of Walsh County, northeastern North Dakota: U.S. Geological Survey Hydrologic Investigations Atlas HA-431.

1973, Ground-water resources, Nelson and Walsh Counties,
North Dakota: North Dakota Geological Survey Bulletin 57, Pt. III, and North Dakota State Water Commission County GroundWater Studies 17, Pt. III, 67 p.

1982, Machine-readable data files from Madison Limestone and northern Great Plains regional aquifer system analysis projects, Montana, Nebraska, North Dakota, South Dakota, and Wyoming: U.S. Geological Survey Water-Resources Investigations 82-4107, $30 \mathrm{p}$.

1983, Bedrock aquifers of the northern Great Plains: American Society of Chemical Engineers Specialty Conference, Jackson, Wyo., 1983, Proceedings, p. 29-35.

1984a, Geohydrology of the Madison and associated aquifers in parts of Montana, North Dakota, South Dakota, and Wyoming: U.S. Geological Survey Professional Paper 1273-G, 47 p.

$1984 \mathrm{~b}$, Hydrodynamics of the Williston basin in the northern Great Plains, in Jorgensen, D.G., and Signor, D.C., eds., Geohydrology of the Dakota aquifer (C.V. Theis Conferences on Geohydrology, 1st, Lincoln, Nebr., 1982, Proceedings): Worthington, Ohio, The National Water Well Association, p. 92-98.

Downey, J.S., and Armstrong, C.A., 1977, Ground-water resources of Griggs and Steele Counties, North Dakota: North Dakota Geological Survey Bulletin 64, Part III, and North Dakota State Water Commission County Ground-Water Studies 21, Part III, $33 \mathrm{p}$.

Downey, J.S., and Paulson, Q.F., 1974, Predictive modeling of effects of the planned Kindred Lake on ground-water levels and discharge, southeastern North Dakota: U.S. Geological Survey WaterResources Investigations 30-74, $22 \mathrm{p}$.

Downey, J.S., and Weiss, E.J., 1980, Preliminary data set for threedimensional digital model of the Red River and Madison aquifers: U.S. Geological Survey open-file report 80-746, 8 p.

Drewes, Harold, 1978, The Cordilleran orogenic belt between Nevada and Chihuahua: Geological Society of America Bulletin, v. 89, no. 8 , p. 641-657.

Duguid, J.O., and Lee, P.C.Y., 1977, Flow in fractured porous media: Water Resources Research, v. 13, no. 3, p. 558-566.

Dunham, R.J., 1961, Geology of uranium in the Chadron area, Nebraska and South Dakota: U.S. Geological Survey open-file report, $243 \mathrm{p}$. 


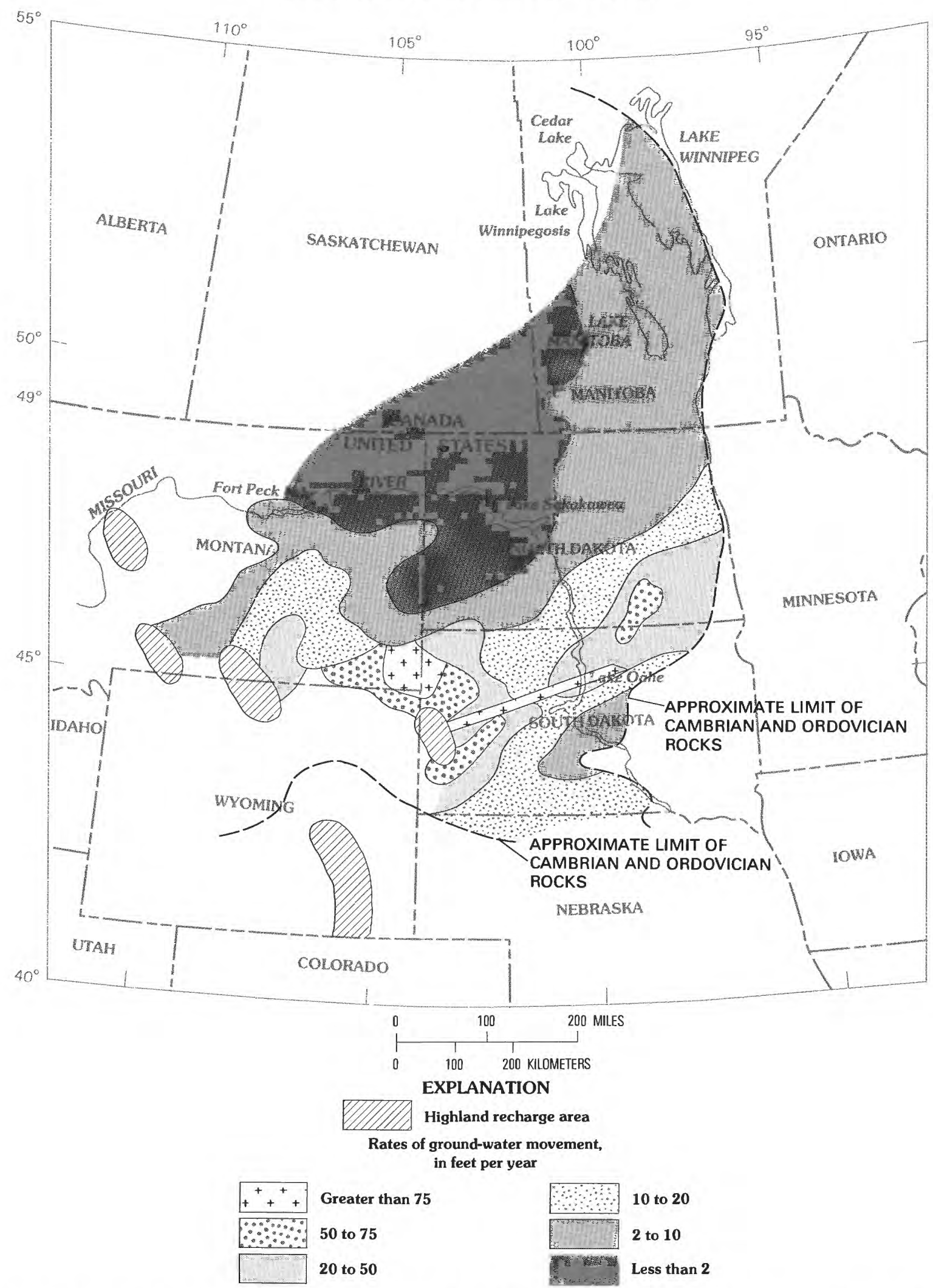

Figure 42.-Calculated rates of ground-water movement in the Cambrian-Ordovician aquifer system, study area and adjacent parts of Canada. 


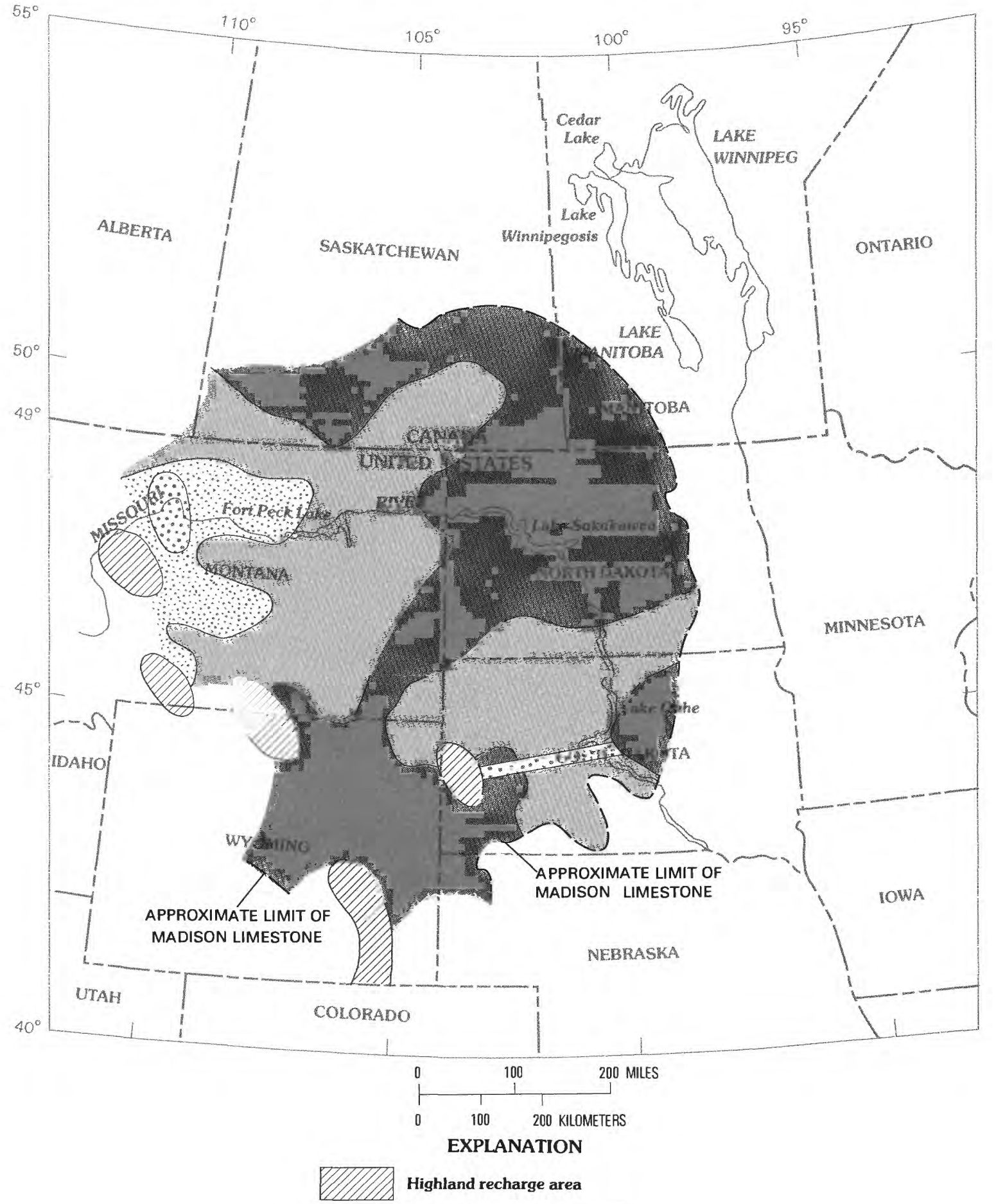

Rates of ground-water movement, in feet per year

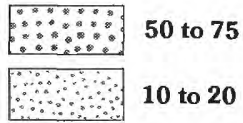

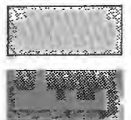

2 to 10

Less than 2

FIGURE 43.-Calculated rates of ground-water movement in the Mississippian aquifer system (including the Madison Limestone), study area and adjacent parts of Canada. 


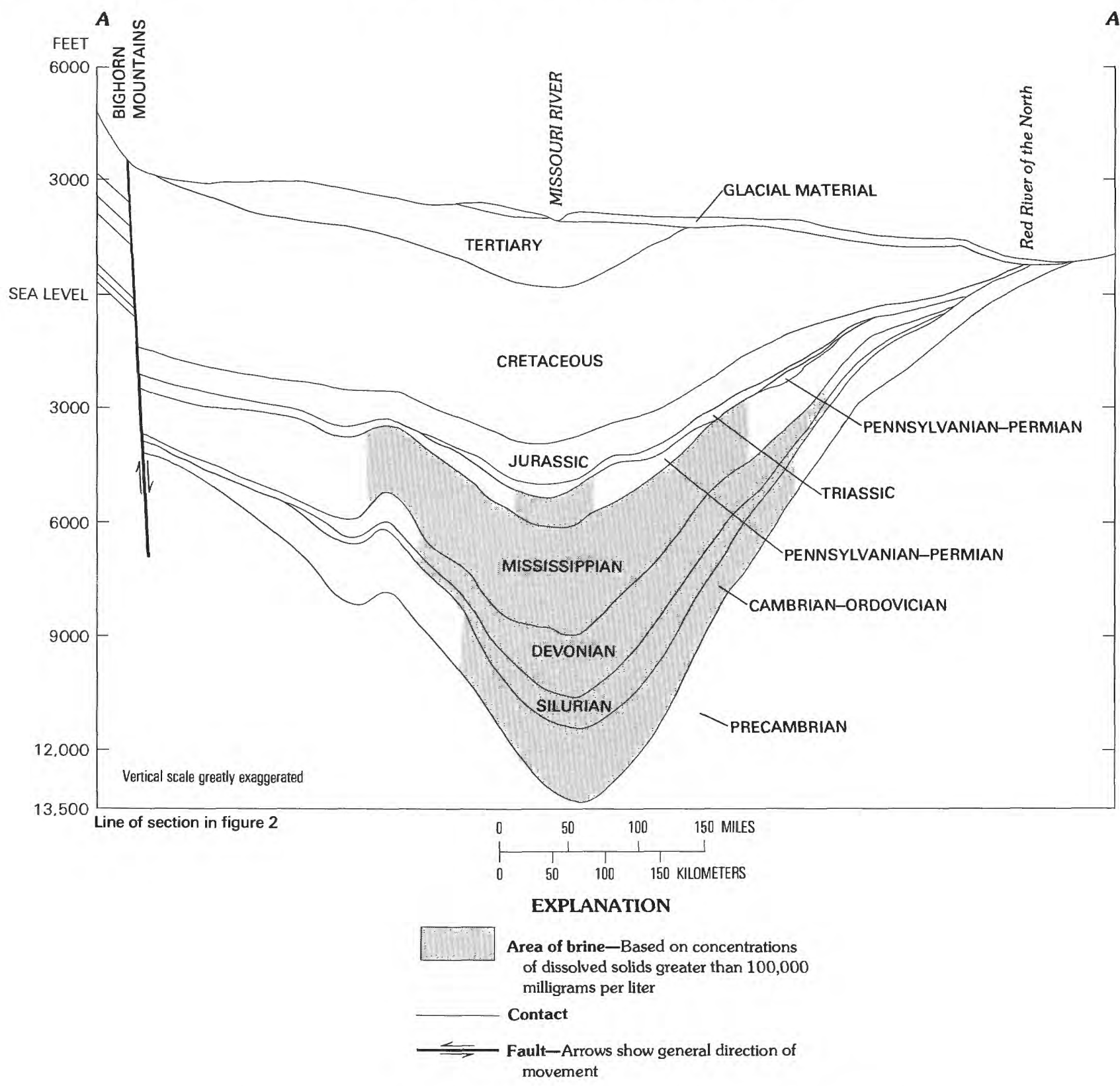

FIGURE 44.-Generalized geohydrologic section showing locations of brine in Williston basin.

Dunham, R.J., 1962, Classification of carbonate rocks according to depositional texture, in Ham, W.E., ed., Classification of carbonate rocks: American Association of Petroleum Geologists Memoir 1, p. 108-121.

Dunlap, C.M., 1958, The Lewis, Fox Hills, and Lance Formations of Upper Cretaceous age in the Powder River basin, Wyoming: Wyoming Geological Association Annual Field Conference, 13th, 1958, Guidebook, p. 109-110.

Dyer, C.F., and Goehring, A.J., 1965, Artesian water supply of the Dakota Formation, southeastern South Dakota: U.S. Geological Survey open-file report, $49 \mathrm{p}$.

Eardley, A.J., 1951, Structural geology of North America: New York, Harper, $624 \mathrm{p}$.
Earle, J.L., 1979, A study of the tectonics of Wyoming and adjacent areas using photo linear elements mapped from Landsat-1 and Skylab imagery, in Podwysocki, M.H., and Earle, J.L., eds., International Conference on New Basement Tectonics, 2d, Newark, Del., 1976, Proceedings: Denver, Basement Tectonics Committee, Inc., p. 165-176.

Earlougher, R.C., Jr., 1977, Advances in well test analysis: Society of the Petroleum Engineers of the American Institute of Mining, Metallurgical, and Petroleum Engineers Monograph, v. 5, 264 p. Egbert, R.L., and Armstrong, E.F., 1970, The use of computerprepared residual maps as an aid in determining sedimentary environments of the Muddy Formation, northeastern Wyoming: The Mountain Geologist, v. 7, no. 4, p. 253-268. 


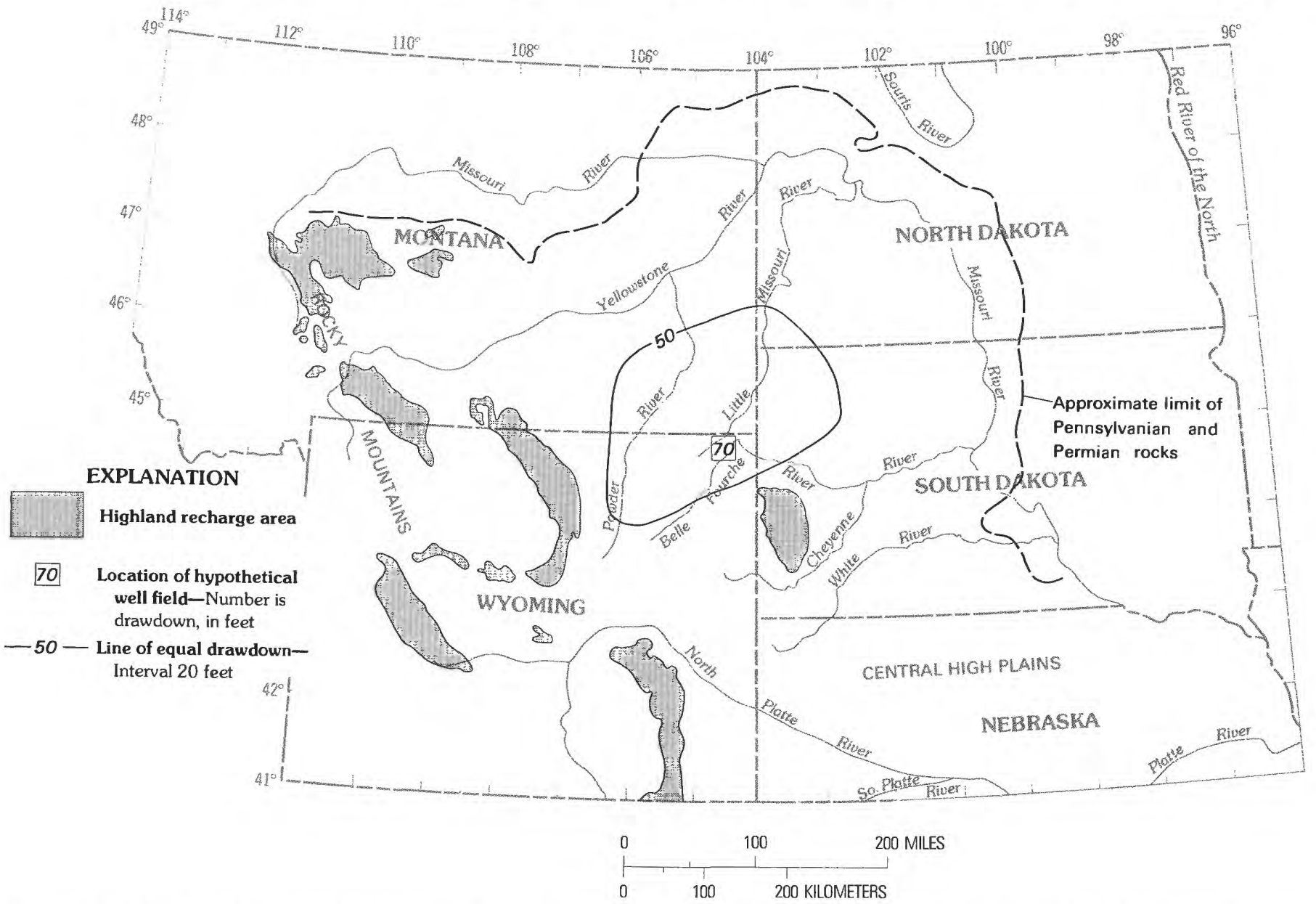

Figure 45.-Calculated drawdown in the Pennsylvanian aquifer system after 5.9 years of hypothetical pumping from the Mississippian aquifer system at a rate of 27.9 cubic feet per second and an assumed storage coefficient of $2.0 \times 10^{-6}$.

El-Etr, H.A., 1976, Proposed terminology for natural linear features, in International Conference on the New Basement Tectonics, 1st, Salt Lake City, Utah, 1974, Utah Geological Association Special Publication no. 5: Salt Lake City, Utah, Utah Geological Association, p. $480-489$.

Ellis, A.J., and Meinzer, O.E., 1924, Ground water in Musselshell and Golden Valley Counties, Montana: U.S. Geological Survey WaterSupply Paper 518, $92 \mathrm{p}$.

Elson, J.A., 1967, Geology of Glacial Lake Agassiz, in Mayer-Oakes, W.J., ed., Life, land and water-Conference on Environmental Studies of the Glacial Lake Agassiz Region, Winnipeg, 1966, Proceedings: Winnipeg, Manitoba, University of Manitoba Press, p. 37-96.

Erickson, H.D., 1954, Artesian conditions in east-central South Dakota: South Dakota State Geological Survey Report of Investigations $74,116 \mathrm{p}$.

1955, Artesian conditions in northeastern South Dakota: South Dakota State Geological Survey Report of Investigations 77, $39 \mathrm{p}$.

Fanshawe, J.R., 1978, Central Montana tectonics and the Tyler Formation: Montana Geological Society Annual Conference, 24th (Williston Basin Symposium), Billings, Mont., 1978, Guidebook, p. 239-248.

Fatt, Irving, and Davis, D.H., 1952, Reduction in permeability with overburden pressure: Transactions of the American Institute of Mining and Metallurgical Engineers, v. 195, p. 329.

Faure, Gunter, 1977, Principles of isotope hydrology: New York, John Wiley, $464 \mathrm{p}$.

Feder, G.L., Lee, R.W., Busby, J.F., and Saindon, L.G., 1977, Geochemistry of ground waters in the Powder River coal region, in Geochemical survey of the western energy regions fourth annual progress report: U.S. Geological Survey Open-File Report 77-872, p. $173-179$.

Feltis, R.D., 1973, Geology and water resources of eastern part of Judith Basin, Montana: Montana Bureau of Mines and Geology Bulletin 87, $51 \mathrm{p}$.

1980 a, Potentiometric surface map of water in the Madison Group, Montana: Montana Bureau of Mines and Geology Hydrologic Map 2, scale 1:1,000,000.

$1980 \mathrm{~b}$, Dissolved-solids and ratio maps of water in the Madison Group, Montana: Montana Bureau of Mines and Geology Hydrologic Map 3, scale 1:1,000,000, 3 sheets.

Feltis, R.D., Lewis, B.D., Frasure, R.L., Rious, R.F., Jauhola, C.A., and Hotchkiss, W.R., 1981, Selected geologic data from the northern Great Plains area of Montana: U.S. Geological Survey WaterResources Investigations Open-File Report 81-415, 63 p.

Fisher, W.L., Brown, L.F., Jr., Scott, A.J., and McGowen, J.H., 1969, Delta systems in the exploration for oil and gas: Austin, Tex., University of Texas Bureau of Economic Geology, 78 p. 


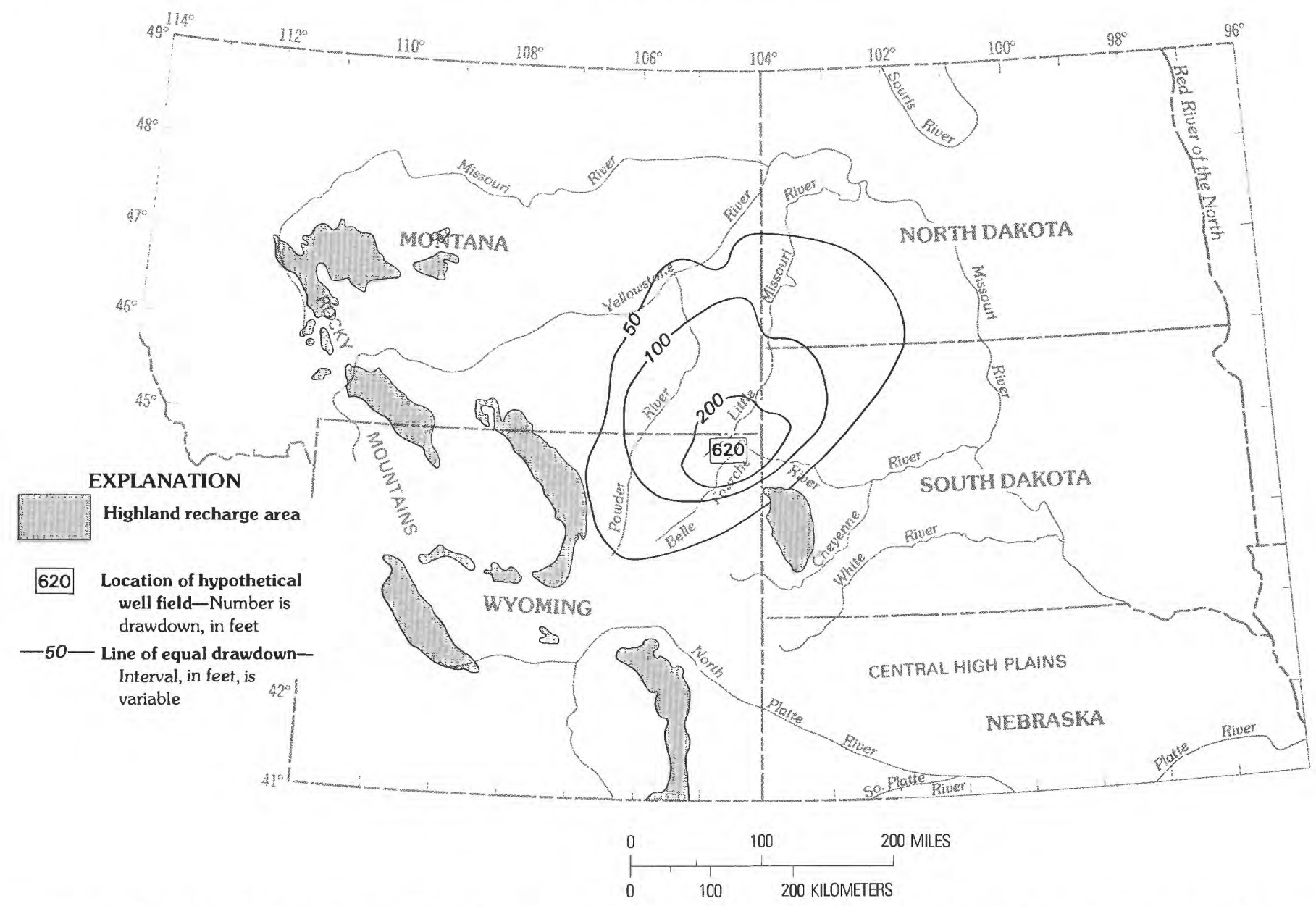

Figure 46.-Calculated drawdown in the Mississippian aquifer system after 5.9 years of hypothetical pumping at a rate of 27.9 cubic feet per second and an assumed storage coefficient of $2.0 \times 10^{-6}$.

Flint, R.F., 1971, Glacial and Quaternary geology: New York, John Wiley, $892 \mathrm{p}$.

Flugel, Erik, Franz, H.E., and Ott, W.F., 1968, Review on electron microscope studies of limestones, in Muller, Guman, and Friedman, G.M., eds., Recent developments in carbonate sedimentology in central Europe: New York, Springer-Verlag, p. 35-97.

Folk, R.L., 1962, Spectral subdivision of limestone types, in Ham, W.E., ed., Classification of carbonate rocks: American Association of Petroleum Geologists Memoir 1, p. 62-84.

Folk, R.L., and Land, L.S., 1975, Mg/Ca ratio and salinity-Two controls over crystallization of dolomite: American Association of Petroleum Geologists Bulletin, v. 59, no. 1, p. 60-68.

Folk, R.L., and Pittman, J.S., 1971, Length-slow chalcedony-A new testament for vanished evaporites: Journal of Sedimentary Petrology, v. 41 , no. 4 , p. $1045-1058$.

Foster, D.I., 1958, Summary of the stratigraphy of the Minnelusa Formation, Powder River basin, Wyoming: Wyoming Geological Association Annual Field Conference, 13th, 1958, Guidebook, p. 39-44.

Foster, M.D., 1950, The origin of high sodium bicarbonate waters in the Atlantic and gulf coastal plains: Geochimica et Cosmochimica Acta, v. 1 , no. 1 , p. $33-48$.

Foster, N.H., 1972, Ordovician system, in Geologic atlas of the Rocky Mountain region: Denver, Rocky Mountain Association of Geologists, p. 76-85.
Foster, N.H., Goodwin, P.E., and Fisher, R.E., 1969, Seismic evidence for high-angle flank faulting, Bighorn Mountains, Wyoming [abs.] Geological Society of America Special Paper 121, p. 100-101.

Fournier, R.O., and Rowe, J.J., 1966, Estimation of underground temperatures from silica content of water from hot springs and wet steam wells: American Journal of Science, v. 264, no. 9, p. $685-690$.

Freeze, R.A., and Cherry, J.A., 1979, Groundwater: Englewood Cliffs, N.J., Prentice Hall, 604 p.

Frickel, D.G., and Shown, L.M., 1974, Map showing streamflow volumes in northeastern Wyoming and southeastern Montana: U.S. Geological Survey Miscellaneous Investigations Map I-847-B.

Friedman, G.M., 1965, Terminology of crystallization textures and fabrics in sedimentary rocks: Journal of Sedimentary Petrology, v. 35 , no. 3 , p. $643-655$.

Frye, C.I., 1969, Stratigraphy of the Hell Creek Formation in North Dakota: North Dakota Geological Survey Bulletin 54, 65 p.

Fuller, J.G.C.M., 1956, Mississippian rocks and oilfields in southeastern Saskatchewan: Saskatchewan Department of Mineral Resources Report 19, 72 p.

1961, Ordovician and contiguous formations in North Dakota, South Dakota, Montana, and adjoining areas in Canada and the United States: American Association of Petroleum Geologists Bulletin, v. 45, no. 8, p. 1334-1363. 


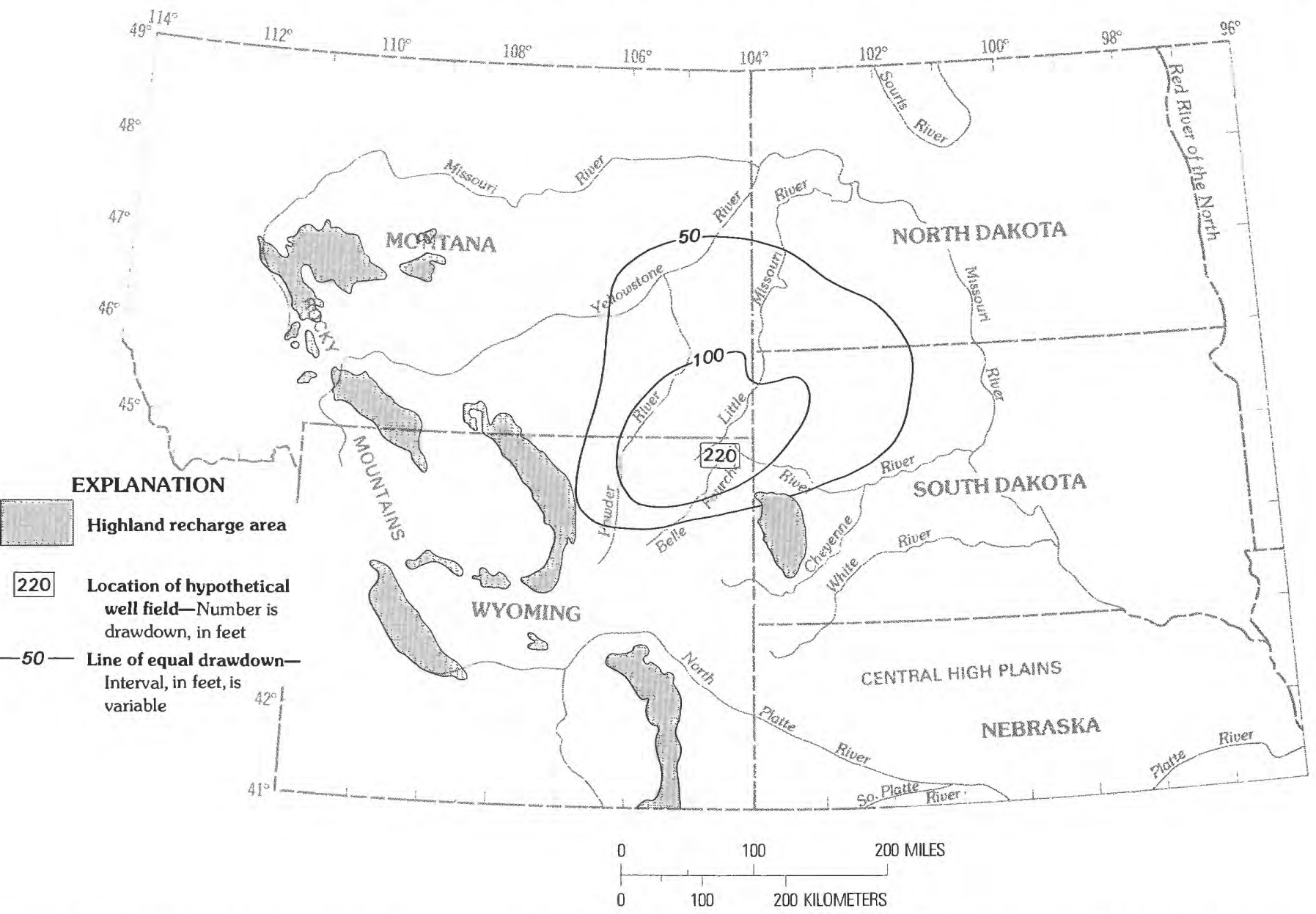

FIGURE 47.-Calculated drawdown in the Cambrian-Ordovician aquifer system after 5.9 years of hypothetical pumping from the Mississippian aquifer system at a rate of 27.9 cubic feet per second and an assumed storage coefficient of $2.0 \times 10^{-6}$.

Gale, J.E., 1977, A numerical, field, and laboratory study of flow in rocks with deformable fractures: Ottawa, Ontario, Inland Waters Directorate, Water Resources Branch Scientific Series 72, 145 p.

Garrels, R.M., and Thompson, M.E., 1962, A chemical model for sea water at $25^{\circ} \mathrm{C}$ and one atmosphere total pressure: American Journal of Science, v. 260 , no. 1 , p. 57-66.

Gast, R.G., and Klobe, W.D., 1971, Sodium-lithium exchange equilibria on vermiculite at $25^{\circ}$ and $50^{\circ} \mathrm{C}$ : Clays and Clay Minerals, v. 19, no. 5 , p. 311-319.

Gat, J.R., 1980, The isotopes of hydrogen and oxygen in precipitation, in Fritz, Peter, and Fontes, J.C., eds., Handbook of environmental isotope geochemistry, part A-The terrestrial environment: New York, Elsevier, p. 21-47.

Gibbs, F.K., 1972, Silurian system, in Geologic atlas of the Rocky Mountain region: Denver, Rocky Mountain Association of Geologists, p. 86-89.

Gill, J.R., and Cobban, W.A., 1965, Stratigraphy of the Pierre Shale, Valley City and Pembina Mountain areas, North Dakota: U.S. Geological Survey Professional Paper 392-A, p. A1-A20.

1966, The Red Bird section of the Upper Cretaceous Pierre Shale in Wyoming, with a section on A new echinoid from the Cretaceous Pierre Shale of eastern Wyoming, by P.M. Kier: U.S. Geological Survey Professional Paper 393-A, 73 p.

1973 , Stratigraphy and geologic history of the Montana Group and equivalent rocks, Montana, Wyoming, and North and
South Dakota: U.S. Geological Survey Professional Paper 776, $37 \mathrm{p}$.

Gilluly, James, 1963, The tectonic evolution of the western United States-17th William Smith Lecture: Quarterly Journal of the Geological Society of London, v. 119, no. 2, p. 133-174.

Ginsburg, R.N., and James, N.P., 1974, Holocene carbonate sediments of continental shelves, in Burk, C.A., and Drake, C.L., eds., The geology of continental margins: New York, Springer-Verlag, p. 137-155.

Glass, G.B., 1976, Update on the Powder River coal basin: Wyoming Geological Association Annual Field Conference, 28th, 1976, Guidebook, p. 209-220.

Goldhaber, M.B., and Kaplan, I.A., 1974, The sulfur cycle, in Goldberg, E.D., ed., The sea: New York, Wiley Interscience, v. 5, p. 569-655.

Gott, G.B., Wolcott, D.E., and Bowles, C.G., 1974, Stratigraphy of Inyan Kara Group and localization of uranium deposits, southern Black Hills, South Dakota and Wyoming: U.S. Geological Survey Professional Paper 763, 57 p.

Gow, A.J., Veda, H.T., and Garfield, D.E., 1968, Antarctic ice sheetPreliminary results of first core hole to bedrock: Science, v. 161, p. 1011-1013.

Grenda, J.C., 1978, Paleozoology of oil-well cores from the Tyler Formation (Pennsylvanian) in North Dakota, United States of America: Montana Geological Society Annual Conference, 24th (Williston Basin Symposium), Billings, Mont., 1978, Guidebook, p. 249-260. 


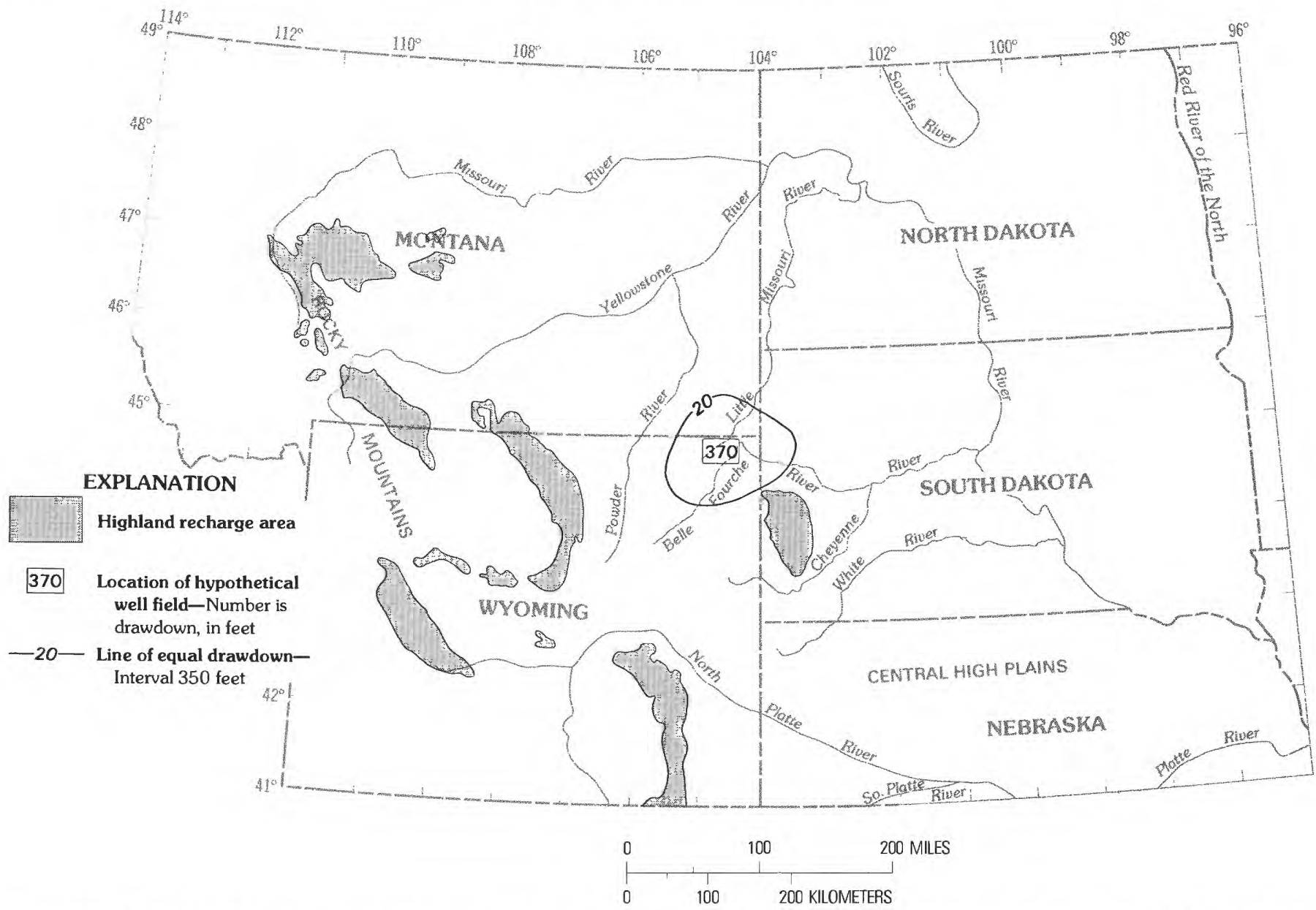

FIGURE 48.-Calculated drawdown in the Mississippian aquifer system after 5.9 years of hypothetical pumping at a rate of 27.9 cubic feet per second and an assumed storage coefficient of $2.0 \times 10^{-4}$.

Gries, J.P., 1954, Cretaceous rocks of the Williston basin: American Association of Petroleum Geologists Bulletin, v. 38, no. 4, p. $443-543$.

1958, The Dakota Formation in central South Dakota: Proceedings of the South Dakota Academy of Science, v. 37, p. 161-168.

1962, Lower Cretaceous stratigraphy of South Dakota and the eastern edge of the Powder River basin: Wyoming Geological Association Annual Field Conference, 17th. 1962, Guidebook, p. 163-172.

1971, Groundwater potential of the Pahasapa Limestone: Proceedings of the South Dakota Academy of Science, v. 50, p. 61-65.

Gries, J.P., and Crooks, T.J., 1968, Water losses to the Madison (Pahasapa) limestone, Black Hills, South Dakota: Wyoming Geological Association Annual Field Conference, 20th, 1968, Guidebook, p. 209-213.

Gries, J.P., and Mickelson, J.C., 1964, Mississippian carbonate rocks in western South Dakota and adjoining areas, in International Williston Basin Symposium, 3d, Regina, Saskatchewan, 1964, Proceedings: Billings, Mont., Billings Geological Society, p. 109-118.

Gries, J.P., Rahn, P.H., and Baker, R.K., 1976, A pump test in the Dakota Sandstone at Wall, South Dakota: South Dakota State Geological Survey Circular 43, 9 p.
Grose, L.T., 1972, Tectonics, in Geologic atlas of the Rocky Mountain region: Denver, Rocky Mountain Association of Geologists, p. $35-44$.

Grossman, I.G., 1968, Origin of the sodium sulfate deposits of the northern Great Plains of Canada and the United States, in Geological Survey research 1968: U.S. Geological Survey Professional Paper 600-B, p. B104-B109.

Grove, D.B., 1976, Ion exchange reactions important in groundwater quality models, in Advances in groundwater hydrology, a symposium of the American Water Resources Association, Chicago, 1976, Proceedings: Minneapolis, St. Anthony Falls Hydraulic Laboratory, p. 144-152.

Hall, G.M., and Howard, C.S., 1929, Ground water in Yellowstone and Treasure Counties, Montana: U.S. Geological Survey WaterSupply Paper 599, 118 p.

Hammerquist, D.W., and Hoskins, E.R., 1969, Correlation of expansive soil properties and soil moisture with pavement distress in roadways in western South Dakota: Rapid City, S. Dak., South Dakota School of Mines and Technology Report, $61 \mathrm{p}$.

Hancock, E.T., 1919, Geology and oil and gas prospects of Lake Basin field, Montana, in Contributions to economic geology, 1918, Pt. II, Mineral fuels: U.S. Geological Survey Bulletin 691-D, p. $101-147$.

Hancock, J.M., 1974, The sequence of facies in the Upper Cretaceous 


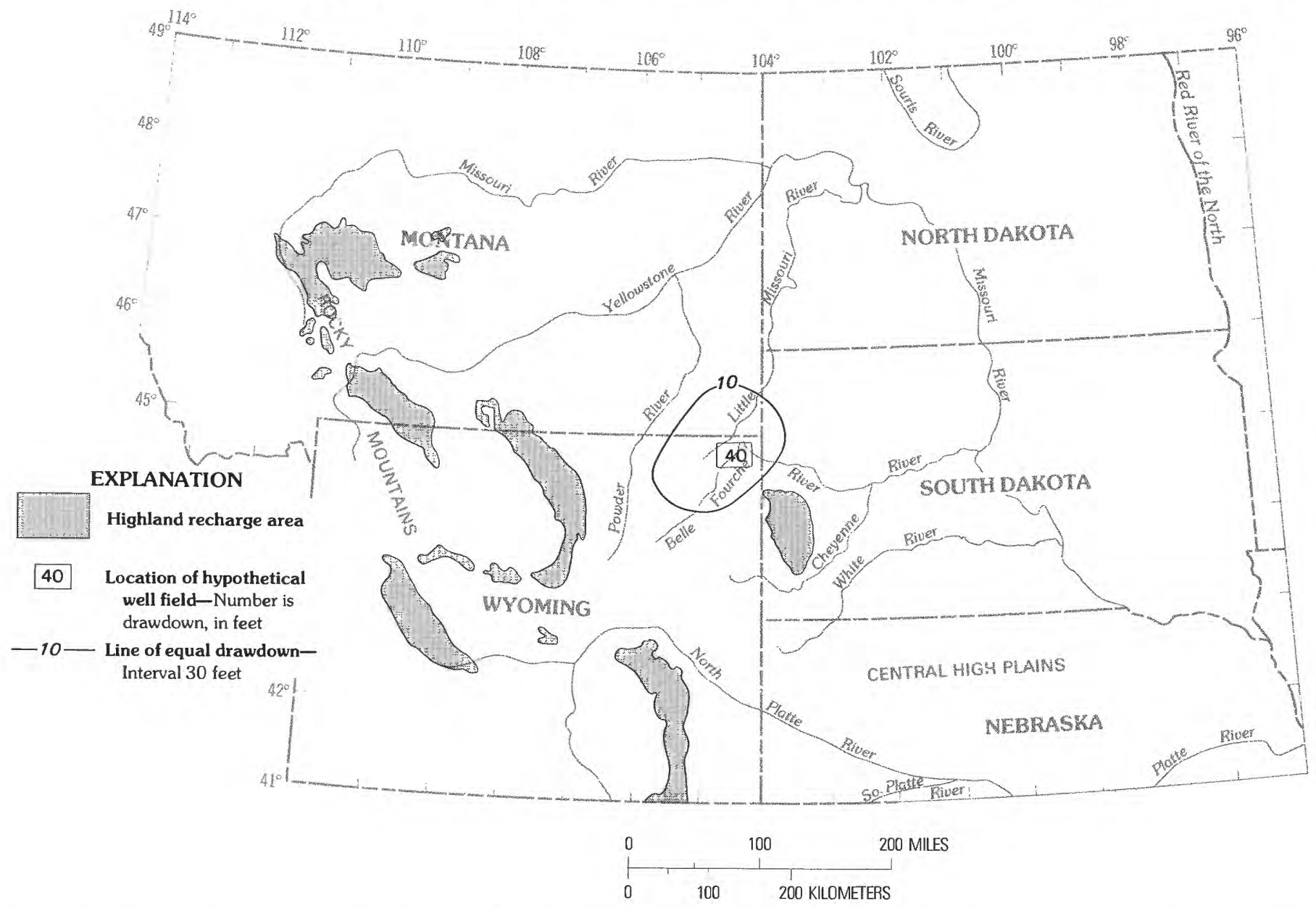

FIGURE 49.-Calculated drawdown in the Cambrian-Ordovician aquifer system after 5.9 years of hypothetical pumping from the Mississippian aquifer system at a rate of 27.9 cubic feet per second and an assumed storage coefficient of $2.0 \times 10^{-4}$.

of northern Europe compared with that in the Western Interior, in Caldwell, W.G.E, ed., Cretaceous system in the Western Interior of North America: Geological Association of Canada Special Publication 13, p. 83-118.

Hanshaw, B.B., and Back, William, 1979, Major geochemical processes in the evolution of carbonate aquifer systems: Journal of Hydrology, v. 43 , nos. 1-4, p. 287-312.

Hanshaw, B.B., Back, William, and Deike, R.G., 1971, A geochemical hypothesis for dolomitization by ground water, in A paleoaquifer and its relation to economic mineral deposits: Economic Geology, v. 66 , no. 5 , p. $710-724$.

Hanshaw, B.B., and Bredehoeft, J.D., 1968, On the maintenance of anomalous fluid pressures-Part 2, Source layer at depth: Geological Society of America Bulletin, v. 79, no. 9, p. 1107-1122.

Hanshaw, B.B., Brown, D.L., Cushing, E.M., Konikow, L.F., and Peterson, J.A., 1977, Hydrogeologic study of a regional carbonaterock aquifer system: Congress of the International Association of Hydrogeologists, 13th, Birmingham, England, 1977, Memoires Series, v. XIII, Part I, p. A24-A35.

Hanshaw, B.B., Busby, J.F., and Lee, R.W., 1978, Geochemical aspects of the Madison aquifer system: Montana Geological Society Annual Conference, 24th (Williston Basin Symposium), Billings, Mont., 1978, Guidebook, p. 385-389.

Hanshaw, B.B., and Coplen, T.B., 1973, Ultrafiltration by a compacted clay membrane-Part 2, Sodium ion exclusion at various ionic strengths: Geochimica et Cosmochimica Acta, v. 37, no. 10, p. 2311-2327.

Hanshaw, B.B., Pearson, F.J., Jr., and Winograd, I.J., 1978, D and O content of Holocene through late Wisconsin PPTN: Geological Society of America Abstracts with Programs, v. 10, no. 7, p. 415.

Hantush, M.S., 1960, Modification of the theory of leaky aquifers: Journal of Geophysical Research, v. 65, no. 11, p. 3713-3725.

Harding, T.P., 1973, Petroleum traps associated with wrench faults: American Association of Petroleum Geologists Bulletin, v. 58, no. 7, p. $1290-1304$.

Harrison, J.E., 1972, Precambrian belt basin of northwestern United States-Its geometry, sedimentation, and copper resources: Geological Society of America Bulletin, v. 83, no. 5, p. 1215-1240.

Haun, J.D., and Barlow, J.A., Jr., 1962, Lower Cretaceous stratigraphy of Wyoming: Wyoming Geological Association Annual Field Conference, 17th, 1962, Guidebook, p. 15-22.

Haun, J.D., Barlow, J.A., Jr., and Hammond, C.R., 1959, Stratigraphy and conditions governing petroleum occurrence in Lower Cretaceous rocks, Rocky Mountain region [abs.]: Geological Record, February 1959, American Association of Petroleum Geologists, Rocky Mountain Section, p. 145-146.

Haun, J.D., and Kent, H.C., 1965, Geologic history of the Rocky 
Mountain region: American Association of Petroleum Geologists Bulletin, v. 49 , no. 11, p. 1781-1800.

Haun, J.D., and Weimer, R.J., 1960, Cretaceous stratigraphy of Colorado, in Weimer, R.J., and Haun, J.D., eds., Guide to geology of Colorado: Denver, Rocky Mountain Association of Geologists, p. $58-65$.

Head, W.J., Kilty, K.T., and Knottek, R.K., 1979, Maps showing formation temperatures and configurations of the tops of the Minnelusa Formation and the Madison Limestone, Powder River basin, Wyoming, Montana, and adjacent areas: U.S. Geological Survey Miscellaneous Investigations Map I-1159.

Head, W.J., and Merkel, R.H., 1977, Hydrologic characteristics of the Madison Limestone, the Minnelusa Formation, and equivalent rocks as determined by well-logging formation evaluation, Wyoming, Montana, South Dakota, and North Dakota: U.S. Geological Survey Journal of Research, v. 5, no. 4, p. 473-485.

Heald, K.C., 1927, The geology of the Ingomar anticline, Treasure and Rosebud Counties, Montana, in Contributions to economic geology, 1926-Pt. II, Mineral Fuels: U.S. Geological Survey Bulletin 786-A, p. 1-37.

Hedge, C.E., 1972, Age of major Precambrian rock units, in Geologic atlas of the Rocky Mountain region: Denver, Rocky Mountain Association of Geologists, p. 54-55.

Hem, J.D., (1959), 1970, Study and interpretation of the chemical characteristics of natural water ( 2 d ed.): U.S. Geological Survey Water-Supply Paper 1473, 363 p.

Henderson, Thomas, 1984, Geochemistry of ground water in two sandstone aquifer systems in the northern Great Plains in parts of Montana, North Dakota, South Dakota, and Wyoming: U.S. Geological Survey Professional Paper 1402-C, 84 p.

Hickey, L.J., 1972, Stratigraphic summary of the Golden Valley Formation (Paleocene-Eocene) of western North Dakota, in Ting, F.T.C., and others, eds., Depositional environments of the lignite bearing strata in western North Dakota: North Dakota Geological Survey Miscellaneous Series 50, p. 105-122.

Hilchie, D.W., 1978, Applied openhole log interpretation (for geologists and engineers): Golden, Colo., Douglas W. Hilchie, Inc., various pagination.

Hitchon, Brian, 1969, Fluid flow in the western Canada sedimentary basin-2, Effect of geology: Water Resources Research, v. 5, no. 2, p. $469-480$.

Hittman Associates, Inc., 1981, Monitoring and modeling of shallow groundwater systems in the Powder River basin: Englewood, Colo., Fourth Annual Technical Report, nonstandard paging.

Hobba, W.A., Jr., Chemerys, J.C., Fisher, D.W., and Pearson, F.J., Jr., 1977, Geochemical and hydrologic data for wells and springs in thermal-spring areas of the Appalachians: U.S. Geological Survey Water-Resources Investigations 77-25, 41 p.

Hoda, Badrul, 1977, Feasibility of subsurface waste disposal in the Newcastle Formation, Lower Dakota Group (CRET) and Minnelusa Formation (PENN), western North Dakota: Detroit, Mich., Wayne State University M.S. thesis, 79 p.

Hodgson, R.A., 1965, Genetic and geometric relations between structures in basement and overlying sedimentary rocks, with examples from Colorado plateau and Wyoming: American Association of Petroleum Geologists Bulletin, v. 49, no. 7, p. 935-949.

Hodson, W.G., 1974, Records of water wells, springs, oil- and gas-test holes, and chemical analyses of water for the Madison Limestone and equivalent rocks in the Powder River basin and adjacent areas, northeastern Wyoming: Wyoming State Engineer Report, $27 \mathrm{p}$.

Hodson, W.G., Pearl, R.H., and Druse, S.A., 1973, Water resources of the Powder River basin and adjacent areas, northeastern Wyoming: U.S. Geological Survey Hydrologic Investigations Atlas HA-465.
Hoefs, Jochen, 1973, Stable isotope geochemistry: Berlin, SpringerVerlag, $140 \mathrm{p}$.

Holser, W.T., and Kaplan, I.R., 1966, Isotope geochemistry of sedimentary sulfates: Chemical Geology, v. 1, no. 2, p. 93-135.

Hooper, W.F., 1962, Lower Cretaceous stratigraphy of the Casper arch, Wyoming: Wyoming Geological Association Annual Field Conference, 17th, 1962, Guidebook, p. 141-147.

Hopkins, W.B., 1978, Deep aquifers of eastern Montana: Montana Geological Society Annual Conference, 24th (Williston Basin Symposium), Billings, Mont., 1978, Guidebook, p. 392-407.

Hoppin, R.A., 1974, Lineaments-Their role in tectonics of central Rocky Mountains: American Association of Petroleum Geologists Bulletin, v. 58 , no. 11 , p. $2260-2273$.

Hoppin, R.A., and Jennings, T.V., 1971, Cenozoic tectonic elements, Bighorn Mountain region, Wyoming-Montana: Wyoming Geological Association Annual Field Conference, 23d, 1971, Guidebook, p. $39-47$.

Hoppin, R.A., and Palmquist, J.C., 1965, Basement influence on later deformation-The problem, techniques of investigation, and examples from Bighorn Mountains, Wyoming: American Association of Petroleum Geologists Bulletin, v. 49, no. 7, p. 993-1003.

Horne, R.A., 1969, Marine chemistry-The structure of water and the chemistry of the hydrosphere: New York, Wiley Interscience, $568 \mathrm{p}$.

Hotchkiss, W.R., 1978, Developing a hydrologic model of the shallow aquifers of the Powder River basin, Montana and Wyoming: National Conference on Energy and the Environment, 5th, Dayton, Ohio, 1978, Proceedings, p. 212-217.

Houston, R.S., 1971, Regional tectonics of the Precambrian rocks of the Wyoming province and its relationship to Laramide structure: Wyoming Geological Association Annual Field Conference, 23d, 1971, Guidebook, p. 19-27.

Howells, L.W., 1974, Geohydrology of Crow Creek and Lower Brule Indian Reservations, South Dakota: U.S. Geological Survey Hydrologic Investigations Atlas HA-499.

1979, Geohydrology of the Cheyenne River Indian Reservation, South Dakota: U.S. Geological Survey Hydrologic Investigations Atlas HA-585.

1982, Geohydrology of the Standing Rock Indian Reservation, North and South Dakota: U.S. Geological Survey Hydrologic Investigations Atlas HA-644.

Howells, L.W., and Stevens, J.C., 1968, Geology and water resources of Beadle County, South Dakota-Part 2, Water resources: South Dakota State Geological Survey Bulletin 18, 65 p.

Hubbert, M.K., 1969, The theory of ground-water motion and related papers: New York, Hafner Publishing Company, 310 p.

Huitt, J.L., 1956, Fluid flow in simulated fractures: AIChE Journal, v. 2 , no. 2 , p. 259-264.

Hunt, J.M., 1980, Petroleum geochemistry and geology: San Francisco, W.H. Freeman, 615 p.

Illies, J.H., and Greiner, Gerhard, 1978, Rhinegraben and the Alpine system: Geological Society of America Bulletin, v. 89, no. 5, p. $770-782$.

Imlay, R.W., 1980, Jurassic paleobiogeography of the conterminous United States in its continental setting: U.S. Geological Survey Professional Paper 1062, 134 p.

Ingram, R.L., 1954, Terminology for the thickness of stratification and parting units in sedimentary rocks: Geological Society of America Bulletin, v. 65 , no. 9, p. 937-938.

Irwin, M.L., 1965, General theory of epeiric clear water sedimentation: Bulletin of the American Association of Petroleum Geologists, v. 49 , no. 4 , p. $445-459$.

Jacob, A.F., 1975, Criteria for differentiating the Tongue River and Sentinel Butte Formations (Paleocene), North Dakota: North Dakota Geological Survey Report of Investigation no. 53, 55 p. 
1976, Geology of the upper part of the Fort Union Group (Paleocene), Williston basin, with reference to uranium: North Dakota Geological Survey Report of Investigation no. 58, 49 p.

Jenkins, M.S., Jr., and McCoy, M.R., 1958, Cambro-Mississippian correlations in the eastern Powder River basin, Wyoming and Montana: Wyoming Geological Association Annual Field Conference, 13th, 1958, Guidebook, p. 31-35.

Jenks, S.E., and Wilson, J.L., 1972, Diagenesis of oolites in Lodgepole Formation (Mississippian), central Montana [abs.]: American Association of Petroleum Geologists Bulletin, v. 56, no. 3, p. $630-631$.

Jennings, T.V., 1967, Structural analysis of the northern Bighorn Mountains, Wyoming: Iowa City, Iowa, University of Iowa Ph. D. dissertation, $224 \mathrm{p}$.

Johnson, W.D., Jr., and Smith, H.R., 1964, Geology of the WinnetMosby area, Petroleum, Garfield, Rosebud, and Fergus Counties, Montana: U.S. Geological Survey Bulletin 1149, 91 p.

Jorgenson, D.G., 1971, Geology and water resources of Bon Homme County, South Dakota-Part 2, Water resources: South Dakota State Geological Survey Bulletin 21, 48 p.

Jorgensen, D.G., and Signor, D.C., eds., 1984, Geohydrology of the Dakota aquifer, in C.V. Theis Conferences on Geohydrology, 1st, Lincoln, Nebr., 1982, Proceedings: Worthington, Ohio, The National Water Well Association, $247 \mathrm{p}$.

Kanasewich, E.R., 1968, Precambrian rift-Genesis of strata-bound ore deposits: Science, v. 161, no. 3845, p. 1002-1005.

Karl, H.A., 1976, Depositional history of Dakota Formation (Cretaceous) sandstones, southeastern Nebraska: Journal of Sedimentary Petrogeology, v. 45, no. 1, p. 124-131.

Keefer, W.R., 1970, Structural geology of the Wind River basin, Wyoming: U.S. Geological Survey Professional Paper 495-D, p. D1-D35.

1974, Regional topography, physiography, and geology of the northern Great Plains: U.S. Geological Survey Open-File Report 74-50, $17 \mathrm{p}$.

Keefer, W.R., and Van Lieu, J.A., 1966, Paleozoic formations in the Wind River basin, Wyoming: U.S. Geological Survey Professional Paper 495-B, $60 \mathrm{p}$.

Keene, J.R., 1973, Ground-water resources of the western half of Fall River County, South Dakota: South Dakota State Geological Survey Report of Investigations 109, $82 \mathrm{p}$.

Kehle, R.O., 1972, Geothermal survey of North America: American Association of Petroleum Geologists Annual Progress Report-1972, $31 \mathrm{p}$.

Kelly, T.E., 1968, Notes on the geohydrology of the Dakota Sandstone, eastern North Dakota, in Geological Survey research 1968: U.S. Geological Survey Professional Paper 600-C, p. C185-C191.

Kendall, A.C., 1979, Facies models 13-Continental and supratidal sebkha evaporites, in Walker, R.G., ed., Facies models: Geoscience Canada Reprint Series 1, p. 145-157.

Kent, D.M., 1964, The geologic history of the Devonian system in the northern Great Plains, in International Williston Basin Symposium, 3d, Regina, Saskatchewan, 1964, Proceedings: Billings, Mont., Billings Geological Society, p. 57-71.

Ketner, K.B., 1968, Origin of Ordovician quartzite in the Cordilleran miogeosyncline, in Geological Survey research 1968: U.S. Geological Survey Professional Paper 600-B, p. B169-B177.

Kindle, E.M., 1914, The Silurian and Devonian section of western Manitoba: Geological Survey of Canada Summary Report for 1912, p. 147-261.

Kinsman, D.J.J., 1969, Modes of formation, sedimentary associations, and diagnostic features of shallow-water and supratidal evaporites: American Association of Petroleum Geologists Bulletin, v. 53, no. 4, p. 830-841.

Knechtel, M.M., 1959, Stratigraphy of the Little Rocky Mountains and encircling foothills, Montana: U.S. Geological Survey Bulletin 1072-N, p. 723-752.

Knechtel, M.M., and Patterson, S.H., 1962, Bentonite deposits of the northern Black Hills district, Wyoming, Montana, and South Dakota: U.S. Geological Survey Bulletin 1082-M, p. 893-1030.

Knight, D.K., 1963, Oahe Dam-Geology, embankment, and cut slopes: Proceedings of the American Society of Civil Engineers, Journal of the Soil Mechanics and Foundations Division, v. 89, no. SM2, pt. 1, p. 99-125.

Koch, N.C., 1970, Geology and water resources of Campbell County, South Dakota-Part 2, Water resources: South Dakota State Geological Survey Bulletin 20, pt. 2, 38 p.

1975, Geology and water resources of Marshall County, South Dakota-Part 2, Water resources: South Dakota State Geological Survey Bulletin 23, 76 p.

1980, Geology and water resources of Hand and Hyde Counties, South Dakota-Part 2, Water resources: South Dakota State Geological Survey Bulletin 28, 46 p.

Koch, N.C., and Bradford, Wendall, 1976, Geology and water resources of Brown County, South Dakota-Part 2, Water resources: South Dakota State Geological Survey Bulletin 25, 53 p.

Konikow, L.F., 1976, Preliminary digital model of ground-water flow in the Madison Group, Powder River basin and adjacent areas, Wyoming, Montana, South Dakota, North Dakota, and Nebraska: U.S. Geological Survey Water-Resources Investigations 63-75, $44 \mathrm{p}$.

1978, Hydrogeologic considerations for an interstate groundwater compact on the Madison aquifer, northern Great Plains: U.S. Geological Survey Open-File Report 78-138, 15 p.

Konikow, L.F., and Grove, D.B., 1977, Derivation of equations describing solute transport in ground water: U.S. Geological Survey Water-Resources Investigations 77-19, 34 p.

Kosanke, R.M., and Cross, A.T., eds., 1966, Symposium on palynology of the Late Cretaceous and Early Tertiary, San Francisco, Calif., 1966: Geological Society of America Special Paper 127, 396 p.

Kososki, B.A., and Robbins, S.L., 1979, In situ bulk density and porosity estimates from borehole gravity data for the Madison Group test well no. 1 in Crook County, Wyoming: U.S. Geological Survey Open-File Report 79-1514, 15 p.

1980a, In-situ bulk density from borehole gravity data in limestones of the Madison Group, test well no. 3, Yellowstone County, Montana: U.S. Geological Survey Open-File Report 80-784, 12 p.

$1980 \mathrm{~b}$, In situ bulk density estimates from borehole gravity data in limestones of the Madison Group, test well no. 2, Custer County, Montana: U.S. Geological Survey Open-File Report 80-982, 12 p.

Kranzler, Irvin, 1966, Origin of oil in lower member of Tyler Formation of central Montana: American Association of Petroleum Geologists Bulletin, v. 50, no. 10, p. 2245-2259.

Kupsch, W.O., 1953, Ordovician and Silurian stratigraphy of eastcentral Saskatchewan: Saskatchewan Geological Survey Department of Natural Resources Report no. 10,62 p.

Laird, W.M., 1944, The geology and ground water resources of the Emerado quadrangle: North Dakota Geological Survey Bulletin $17,35 \mathrm{p}$.

Land, L.S., Salem, M.R.I., and Morrow, D.W., 1975, Paleohydrology of ancient dolomites-Geochemical evidence: American Association of Petroleum Geologists Bulletin, v. 59, no. 9, p. 1602-1625.

Landes, K.K., 1970, Petroleum geology of the United States: New York, John Wiley, 571 p.

Lange, N.A., compiler, 1969, Handbook of chemistry (10th ed.): New York, McGraw Hill, 2,001 p.

Langmuir, Donald, 1978, Uranium solution-mineral equilibria at low temperatures with application to sedimentary ore deposits: Geochimica et Cosmochimica Acta, v. 42, no. 6, p. 547-569. 
Law, B.E., Barnum, B.E., and Galyardt, G.L., 1975, Tectonic implications of the Fort Union Formation, northwestern Powder River basin, Wyoming and Montana: Geological Society of America Abstracts with Programs, v. 7, no. 7, p. 1163.

Lee, R.W., 1979, Ground-water quality from the northern Powder River basin, southeastern Montana: U.S. Geological Survey Water-Resources Investigations Open-File Report 79-1331, 59 p.

Lenfest, L.W., Jr., 1984 (1982), Evapotranspiration rates at selected sites in the Powder River basin, Wyoming and Montana: U.S. Geological Survey Water-Resources Investigations 82-4105, $35 \mathrm{p}$.

Levings, G.W., 1981a, Selected drill-stem-test data from the northern Great Plains area of Montana: U.S. Geological Survey WaterResources Investigations Open-File Report 81-326, 20 p.

$1981 \mathrm{~b}$, Selected hydrogeologic data from the northern Great Plains area of Montana: U.S. Geological Survey Open-File Report 81-534, 244 p.

1982, Potentiometric-surface map of water in the Fox HillsLower Hell Creek aquifer in the northern Great Plains area of Montana: U.S. Geological Survey Open-File Report 82-564, scale $1: 1,000,000$.

Levings, J.F., and Dodge, K.A., 1981, Selected hydrogeologic data from the Judith Basin, central Montana: U.S. Geological Survey Open-File Report 81-1015, 102 p.

Levings, J.F., Levings, G.W., Feltis, R.D., Hotchkiss, W.R., and Lee, R.W., 1981, Selective annotated bibliography of geology and ground-water resources for the Montana part of the northern Great Plains regional aquifer-system analysis: U.S. Geological Survey Open-File Report 81-401, 93 p.

Lewis, B.D., and Hotchkiss, W.R., 1981, Thickness, percent sand, and configuration of shallow hydrogeologic units in the Powder River basin, Montana and Wyoming: U.S. Geological Survey Miscellaneous Investigations Series Map I-1317, scale 1:1,000,000, 6 sheets.

Lewis, B.D., and Roberts, R.S., 1978, Geology and water-yielding characteristics of rocks of the northern Powder River basin, southeastern Montana: U.S. Geological Survey Miscellaneous Investigations Series Map I-847-D, scale 1:250,000, 2 sheets.

Liley, P.E., and Gambill, W.R., 1973, Physical and chemical data, in Perry, R.H., and Chilton, C.H., eds., Chemical engineers handbook: New York, McGraw Hill, p. 3-1 to 3-250.

Lippmann, Frederick, 1973, Sedimentary carbonate minerals: Berlin, Springer-Verlag, $228 \mathrm{p}$.

Lisenbee, A.L., 1978, Laramide structure of the Black Hills uplift, South Dakota-Wyoming-Montana, in Matthews, Vincent, III, ed., Laramide folding associated with basement block faulting in the western United States: Geological Society of America Memoir 151, p. $165-196$.

Lobmeyer, D.H., 1980, Preliminary potentiometric-surface map showing freshwater heads for the Lower Cretaceous rocks in the northern Great Plains of Montana, North Dakota, South Dakota, and Wyoming: U.S. Geological Survey Open-File Report 80-757, scale 1:1,000,000.

1982, Preliminary data for northern Great Plains test well 1, NW1/4NE1/4 sec. 11, T. 55 N., R. 77 W., Sheridan County, Wyoming: U.S. Geological Survey Open-File Report 82-446, 80 p.

1985, Freshwater heads and ground-water temperature in aquifers of the northern Great Plains in parts of Montana, North Dakota, South Dakota, and Wyoming: U.S. Geological Survey Professional Paper 1402-D, 11 p.

Lobmeyer, D.H., Anna, L.O., and Busby, J.F., 1982, Preliminary data for northern Great Plains test well 1, NW1/4 NE $1 / 4$ sec. 11, T. 55 N., R. 77 W., Sheridan County, Wyoming: U.S. Geological Survey Open-File Report 82-446, 80 p.

Lochman-Balk, Christina, 1972, Cambrian system, in Geologic atlas of the Rocky Mountain region: Denver, Rocky Mountain Association of Geologists, p. 60-75.

Lochman-Balk, Christina, and Wilson, J.L., 1967, Stratigraphy of Upper Cambrian-Lower Ordovician subsurface sequence in the Williston basin: American Association of Petroleum Geologists Bulletin, v. 51, no. 6, p. 883-917.

Lockridge, J.P., and Scholle, P.A., 1978, Niobrara gas in eastern Colorado and northwestern Kansas, in Pruitt, J.D., ed., Energy resources of the Denver Basin:' Rocky Mountain Association of Geologists Field Conference Guidebook, v. 1978, p. 35-49.

Lohman, S.W., 1979, Ground-water hydraulics: U.S. Geological Survey Professional Paper 708, 70 p.

Lohman, S.W., and others, 1972, Definitions of selected ground-water terms-Revisions and conceptual refinements: U.S. Geological Survey Water-Supply Paper 1988, 21 p.

Love, J.D., 1960, Cenozoic sedimentation and crustal movement in Wyoming: American Journal of Science, v. 258-A, p. 204-214.

Love, J.D., McGrew, P.O., and Thomas, H.D., 1963, Relationship of latest Cretaceous and Tertiary deposition and deformation to oil and gas in Wyoming: Geological Society of America Memoir 2, p. 196-208.

Lowell, J.D., 1974, Plate tectonics and foreland basement deformation: Geology, v. 2, no. 6, p. 275-361.

Lowry, M.E., 1981, The relative importance of regional and local ground-water systems in the Powder River structural basin, Wyoming and Montana [abs.]: Annual Rocky Mountain Groundwater Conference, 10th, Laramie, Wyo., 1981, Proceedings, p. 71.

Lucia, F.J., 1962, Diagenesis of a crinoidal sediment: Journal of Sedimentary Petrology, v. 32, no. 4, p. 848-865.

1972, Recognition of evaporite-carbonate shoreline sedimentation, in Rigby, J.K., and Hamblin, W.K., eds., Recognition of ancient sedimentary environments: Society of Economic Paleontologists and Mineralogists Special Publication 16, p. 160-191.

Ludvigson, G.A., and Bunker, G.J., 1979, Status of hydrogeologic studies in northwest Iowa: Iowa Geological Survey open-file report, $37 \mathrm{p}$.

MacCary, L.M., 1984, Apparent water resistivity, porosity, and ground-water temperature of the Madison Limestone and underlying rocks in parts of Montana, Nebraska, North Dakota, South Dakota, and Wyoming: U.S. Geological Survey Professional Paper 1273-D, $14 \mathrm{p}$.

MacCary, L.M., Cushing, E.M., and Brown, D.L., 1983, Potentially favorable areas for large-yield wells in the Red River Formation and Madison Limestone in parts of Montana, North Dakota, South Dakota, Wyoming, and Nebraska: U.S. Geological Survey Professional Paper 1273-E, 13 p.

MacKenzie, D.B., and Poole, D.M., 1962, Provenance of Dakota Group sandstones of the Western Interior: Wyoming Geological Association Annual Field Conference, 17th, 1962, Guidebook, p. 62-71.

Maier, L.F., and Ripley, H.E., 1967, Formation evaluation by drill stem testing: Ontario Petroleum Institute Conference, 6th, London, Ontario, 1967, Proceedings, $32 \mathrm{p}$.

Mallory, W.W., 1967, Pennsylvanian and associated rocks in Wyoming: U.S. Geological Survey Professional Paper 554-G, 31 p. 1972, Regional synthesis of the Pennsylvania system, in Geologic atlas of the Rocky Mountain region: Denver, Rocky Mountain Association of Geologists, p. 111-127.

Mapel, W.J., and Pillmore, C.L., 1962, Stream directions in the Lakota Formation (Cretaceous) in the northern Black Hills, Wyoming and South Dakota, in Short papers in geology, hydrology, and topography: U.S. Geological Survey Professional Paper 450-B, p. B35-B37.

Matthews, Vincent, III, 1981, Regional stresses and deformation associated with arc-trench complexes and the Wyoming foreland province-A different view, in Boyd, D.W., ed., Rocky Mountain 
Foreland basement tectonics: Contributions to Geology, v. 19, no. 2, p. 123-126.

Matthews, Vincent, III, ed., 1978, Laramide folding associated with basement block faulting in the western United States: Geological Society of America Memoir 151, $370 \mathrm{p}$.

Maughan, E.K., 1963, Mississippian rocks in the Laramie Range, Wyoming, and adjacent areas, in Short papers in geology and hydrology: U.S. Geological Survey Professional Paper 475-C, p. C23-C27.

1966, Environment of deposition of Permian salt in Williston and Alliance basins, in Rau, J.L., ed., Symposium on salt, geology, geochemistry, mining, 2d, Cleveland, Ohio, 1966, Proceedings, v. 1: Cleveland, Northern Ohio Geological Scciety, p. 35-47.

1967, Eastern Wyoming, eastern Montana, and the Dakotas, in McKee, E.D., Oriel, S.S., and others, Paleotectonic investigations of the Permian system in the United States: U.S. Geological Survey Professional Paper 515-G, p. 125-152.

1975, Montana, North Dakota, northeastern Wyoming, and northern South Dakota, in McKee, E.D., Crosby, E.J., and others, eds., Paleotectonic investigations of the Pennsylvanian system in the United States-Part I, Introduction and regional analyses of the Pennsylvanian system: U.S. Geological Survey Professional Paper 853-O, p. 279-293.

Maughan, E.K., and Roberts, A.E., 1967, Big Snowy and Amsden Groups and the Mississippian-Pennsylvanian boundary in Montana: U.S. Geological Survey Professional Paper 554-B, 27 p.

McCabe, H.R., 1963, Mississippian oil fields of southwestern Manitoba: Manitoba Department of Mines and Natural Resources Mines Branch Publication 60-5, 50 p.

McCabe, W.S., 1954, Williston basin Paleozoic unconformities: American Association of Petroleum Geologists Bulletin, v. 38, no. 9, p. 1997-2010.

McCaleb, J.A., and Wayhan, D.A., 1969, Geologic reservoir analysis, Mississippian Madison Formation, Elk basin field, WyomingMontana: American Association of Petroleum Geologists Bulletin, v. 53 , no. 10 , p. $2094-2113$.

McCoy, M.R., 1952, Ordovician sediments in the northern Black Hills: Billings Geological Society Annual Field Conference, 3d, 1952, Guidebook, p. 44-47.

McGinnis, L.D., 1968, Glaciation as a possible cause of mineral deposition: Economic Geology, v. 63, no. 4, p. 390-400.

McGrew, P.O., 1971, The Tertiary history of Wyoming: Wyoming Geological Association Annual Field Conference, 23d, 1971, Guidebook, p. 29-33.

McKinstry, H.E., 1953, Shears of the second order: American Journal of Science, v. 251, no. 6, p. 401-414.

McMannis, W.J., 1965, Résumé of depositional and structural history of western Montana: American Association of Petroleum Geologists Bulletin, v. 49 , no. 11, p. 1801-1823.

Meinzer, O.E., 1929, Problems of the soft-water supply of the Dakota sandstone, with special reference to the conditions at Canton, South Dakota, in Contributions to the hydrology of the United States, 1928: U.S. Geological Survey Water-Supply Paper 597-C, p. $147-170$.

Meissner, F.F., 1978, Petroleum geology of the Bakken Formation, Williston basin, North Dakota and Montana: Montana Geological Society Annual Conference, 24th (Williston Basin Symposium), Billings, Mont., 1978, Guidebook, p. 17-31.

Mereweather, E.A., and Cobban, W.A., 1981, Mid-Cretaceous formations in eastern South Dakota and adjoining areas-Stratigraphic, paleontologic and structural interpretation, in Brenner, R.L., and others, eds., Cretaceous stratigraphy and sedimentation in northwest Iowa, northeast Nebraska, and southeast South Dakota: Iowa Geological Survey Guidebook Series 4, p. 43-56.

Mereweather, E.A., Cobban, W.A., and Spencer, C.W., 1976, The
Upper Cretaceous Frontier Formation in the Kaycee-Tisdale Mountain area, Johnson County, Wyoming: Wyoming Geological Association Annual Field Conference, 28th, 1976, Guidebook, p. 33-44.

Mettler, D.E., 1966, West Moorcroft Dakota field, Crook County, Wyoming: The Mountain Geologist, v. 3, no. 2, p. 89-92.

Meyboom, Peter, 1966, Groundwater studies in the Assiniboine River drainage basin: Geological Survey of Canada Bulletin 139, 65 p.

Meyer, R.R., 1963, A chart relating well diameter, specific capacity, and coefficients of transmissibility and storage, in Bentall, Ray, compiler, Methods of determining permeability, transmissibility, and drawdown: U.S. Geological Survey Water-Supply Paper 1536-I, p. 338-340.

Michelson, J.C., 1956, Madison Group in central Montana: Billings Geological Society Annual Field Conference, 7th, 1956, Guidebook, p. 68-72.

Middleton, G.V., 1961, Evaporite solution breccias from the Mississippian of southwest Montana: Journal of Sedimentary Petrology, v. 31 , no. 2 , p. $189-195$.

Miller, D.N., Jr., 1962, Patterns of barrier bar sedimentation and its similarity to Lower Cretaceous Fall River stratigraphy: Wyoming Geological Association Annual Field Conference, 17th, 1962, Guidebook, p. 232-247.

1966, Diagenesis of sedimentary rocks: Wyoming Geological Association Annual Conference, 12th (Symposium on Recently Developed Geologic Principles and Sedimentation of the PermoPennsylvanian of the Rocky Mountains), Casper, Wyo., 1966, Proceedings, p. 17-21.

Miller, M.R., 1969, Water resources of eastern Montana: Montana Geological Society Annual Conference, 20th (Eastern Montana Symposium), Billings, Mont., 1969, Proceedings, p. 237-243.

Miller, R.H., and Rahn, P.H., 1974, Recharge to the Dakota Sandstone from outcrops in the Black Hills, South Dakota: Association of Engineering Geologists Bulletin, v. 11, no. 3, p. 221-234.

Miller, W.R., 1976, Water in carbonate rocks of the Madison Group in southeastern Montana-A preliminary evaluation: U.S. Geological Survey Water-Supply Paper 2043, 51 p.

1979a, Water resources of the central Powder River area of southeastern Montana: Montana Bureau of Mines and Geology Bulletin 108, 65 p.

$1979 \mathrm{~b}$, Water resources of the southern Powder River area of southeastern Montana: U.S. Geological Survey Open-File Report 79-343, $140 \mathrm{p}$.

Miller, W.R., and Strausz, S.A., 1980a, Preliminary map showing freshwater heads for the Red River Formation, Bighorn Dolomite, and equivalent rocks of Ordovician age in the northern Great Plains of Montana, North Dakota, South Dakota, and Wyoming: U.S. Geological Survey Open-File Report 80-730, scale 1:1,000,000.

$1980 \mathrm{~b}$, Preliminary map showing freshwater heads for the Mission Canyon and Lodgepole limestones and equivalent rocks of Mississippian age in the northern Great Plains of Montana, North Dakota, South Dakota, and Wyoming: U.S. Geological Survey Open-File Report 80-729, scale 1:1,000,000.

Milliken, K.L., 1979, The silicified evaporite syndrome-Two aspects of silicification history of former evaporite nodules from southern Kentucky and northern Tennessee: Journal of Sedimentary Petrology, v. 49, no. 1, p. 245-256.

Milly, P.C.D., 1978, Mathematical models of groundwater flow and sulphate transport in the major aquifers of South Dakota: Princeton, N.J., Princeton University M.S. thesis, 46 p.

Milner, R.L., 1956, Effects of salt solution in Saskatchewan, in International Williston Basin Symposium, 1st, Bismarck, N. Dak., 1956, Proceedings [abs.]: Bismarck, N. Dak., North Dakota Geological Society, p. 111.

Moody, J.D., and Hill, M.J., 1956, Wrench-fault tectonics: Geological Society of America Bulletin, v. 67, no. 9, p. 1207-1246. 
1958, Wrench-fault tectonics-A response: Geological Society of America Bulletin, v. 69, no. 7, p. 929-930.

1964, Moody and Hill system of wrench-fault tectonics-Reply: American Association of Petroleum Geologists Bulletin, v. 48, no. 1 , p. 112-122.

Mook, W.G., 1980, Carbon-14 in hydrogeological studies, in Fritz, Peter, and Fontes, J.C., eds., Handbook of environmental isotope geochemistry, part A-The terrestrial environment: New York, Elsevier, p. 49-71.

Moore, W.L., 1976, The stratigraphy and environments of deposition of the Cretaceous Hell Creek Formation (reconnaissance) and the Paleocene Ludlow Formation (detailed), southwestern North Dakota: North Dakota Geological Survey Report of Investigation no. $56,40 \mathrm{p}$.

Muehlberger, W.R., Denison, R.E., and Lidiak, E.G., 1967, Basement rocks in continental interior of United States: American Association of Petroleum Geologists Bulletin, v. 51, no. 12, p. 2351-2380.

Murphy, W.C., 1965, The interpretation and calculation of formation characteristics from formation test data: Duncan, Okla., Halliburton Services Division, Halliburton Company, 19 p.

Murray, R.C., 1960, Origin of porosity in carbonate rocks: Journal of Sedimentary Petrology, v. 30 , no. 1 , p. 59-84.

1964, Origin and diagenesis of gypsum and anhydrite: Journal of Sedimentary Petrology, v. 34, no. 3, p. 512-523.

Murray, R.C., and Lucia, F.J., 1967, Cause and control of dolomite distribution of rock selectivity: Geological Society of America Bulletin, v. 78, no. 1, p. 21-35.

Neglia, S., 1979, Migration of fluids in sedimentary basins: American Association of Petroleum Geologists Bulletin, v. 63, no. 4, p. 573-597.

Neuman, S.P., and Witherspoon, P.A., 1968, Theory of flow in aquicludes adjacent to slightly leaky aquifers: Water Resources Research, v. 4, no. 1, p. 103-112.

Neuzil, C.E., 1980, Fracture leakage in the Cretaceous Pierre Shale and its significance for underground waste disposal: Baltimore, Md., Johns Hopkins University Ph. D. dissertation, 150 p.

Niven, D.W., 1967, Determination of porosity and permeability of selected sandstone aquifers of South Dakota: Rapid City, S. Dak., South Dakota School of Mines and Technology M.S. thesis, 31 p.

Nordquist, J.W., 1953, Mississippian stratigraphy of northern Montana: Billings Geological Society Annual Field Conference, 4th, 1953, Guidebook, p. 68-82.

1955, Pre-Rierdon Jurassic stratigraphy in northern Montana and Williston basin: Billings Geological Society, Annual Field Conference, 6th, 1955, Guidebook, p. 96-106.

Northern Great Plains Resources Program, 1975, Effects of coal development in the northern Great Plains: Denver, Northern Great Plains Resources Program, 165 p.

Norton, G.H., 1956, Evidences of unconformity in rocks of Carboniferous age in central Montana: Billings Geological Society Annual Field Conference, 7th, 1956, Guidebook, p. 52-66.

Norwood, E.E., 1965, Geological history of central and south-central Montana: American Association of Petroleum Geologists Bulletin, v. 49 , no. 11 , p. $1824-1832$.

O'Leary, D.W., Friedman, J.D., and Pohn, H.A., 1979, Lineament and linear, a terminological reappraisal, in Podwysocki, M.H., and Earle, J.L., eds., International Conference on New Basement Tectonics, 2d, Newark, Del., 1976, Proceedings: Denver, Basement Tectonics Committee, Inc., p. 571-577.

Olsen, H.W., 1969, Simultaneous fluxes of liquid and charge in saturated kaolinite: Soil Science Society of America Proceedings, v. 33 , no. 3 , p. $338-344$.

1972, Liquid movement through kaolinite under hydraulic, electrical, and osmotic gradients: American Association of Petroleum Geologists Bulletin, v. 56, no. 10, p. 2022-2028.
Olson, G.J., Dockins, W.S., McFeters, G.A., and Iverson, W.P., 1981, Sulfate reducing bacteria from deep aquifers in Montana: Geomicrobiology Journal, v. 2, no. 4, p. 327-340.

Oriel, S.S., 1959, Lithofacies-Thickness maps and subdivisions of the Triassic system, in McKee, E.D., and others, eds., Paleotectonic maps, Triassic system: U.S. Geological Survey Miscellaneous Geologic Investigations Map I-300, scale 1:5,000,000.

Osterwald, F.W., and Dean, B.A., 1958, Preliminary tectonic maps, showing distribution of uranium deposits, eastern Montana: U.S. Geological Survey Miscellaneous Field Studies Map MF-126, scale $1: 500,000,2$ sheets.

Parker, J.M., 1958, Stratigraphy of the Shannon Member of the Eagle Formation and its relationship to other units in the Montana Group in the Powder River basin, Wyoming and Montana: Wyoming Geological Association Annual Field Conference, 13th, 1958, Guidebook, p. 90-99.

Partridge, J.F., Jr., 1957, Potential stratigraphic oil accumulations in Upper Cretaceous sands, Powder River basin, Wyoming: American Association of Petroleum Geologists Bulletin, v. 41, no. 5, p. 882-893.

Patterson, J.R., 1961, Ordovician stratigraphy and correlations in North America: American Association of Petroleum Geologists Bulletin, v. 45, no. 6, p. 1364-1377.

Peter, K.D., 1984, Hydrochemistry of Lower Cretaceous sandstone aquifers, northern Great Plains, in Jorgensen, D.G., and Signor, D.C., eds., Geohydrology of the Dakota aquifer (C.V. Theis Conferences on Geohydrology, 1st, Lincoln, Nebr., 1982, Proceedings): Worthington, Ohio, The National Water Well Association, p. 197-208.

Peterson, J.A., 1957, Marine Jurassic of the northern Rocky Mountains and Williston basin: American Association of Petroleum Geologists Bulletin, v. 41, no. 3, p. 399-440.

1966, Sedimentary history of the Sweetgrass arch: Billings Geological Society Annual Field Conference, 17th, 1966, Guidebook, p. 112-133.

1972, Jurassic system, in Geologic atlas of the Rocky Mountain region: Denver, Rocky Mountain Association of Geologists, p. 177-189.

1978, Subsurface geology and porosity distribution, Madison Limestone and underlying formations, Powder River basin, northeastern Wyoming and southeastern Montana and adjacent areas: U.S. Geological Survey Open-File Report 78-783, 32 p.

1980a, Depositional history and petroleum geology of the Permian Phosphoria, Park City, and Shedhorn Formations, Wyoming and southeastern Idaho: U.S. Geological Survey Open-File Report 80-667, $51 \mathrm{p}$.

$1980 \mathrm{~b}$, Permian paleogeography and sedimentary provinces, west-central United States, in Fouch, T.D., and Magathan, E.R., eds., Symposium of Paleozoic Paleogeography of West-Central United States, 1st, Denver, 1980, Proceedings: Denver, Society of Economic Paleontologists and Mineralogists, p. 271-292.

1981, Stratigraphy and sedimentary facies of the Madison Limestone and associated rocks in parts of Montana, North Dakota, South Dakota, Wyoming, and Nebraska: U.S. Geological Survey Open-File Report 81-642, 92 p.

Pinder, G.F., and Bredehoeft, J.D., 1968, Application of the digital computer for aquifer evaluation: Water Resources Research, v. 4 , no. 5, p. 1069-1093.

Plummer, L.N., 1977, Defining reactions and mass transfer in part of the Floridan aquifer: Water Resources Research, v. 13, no. 5, p. 801-812.

Plummer, L.N., and Back, William, 1980, The mass balance approachApplication to interpreting the chemical evolution of hydrologic systems: American Journal of Science, v. 280, no. 2, p. 130-142. Plummer, L.N., Jones, B.F., and Truesdell, A.H., 1976, WATEQF- 
A FORTRAN IV version of WATEQ, a computer program for calculating chemical equilibrium of natural waters: U.S. Geological Survey Water-Resources Investigations 76-13, $66 \mathrm{p}$.

Poland, J.F., Lofgren, B.E., and Riley, F.S., 1972, Glossary of selected terms useful in studies of the mechanics of aquifer systems and land subsidence due to fluid withdrawal: U.S. Geological Survey Water-Supply Paper 2025, 9 p.

Porter, J.W., and Fuller, J.G.C.M., 1959, Lower Paleozoic rocks of northern Williston basin and adjacent areas: American Association of Petroleum Geologists Bulletin, v. 43, no. 1, p. 124-189.

1964, Ordovician-Silurian, in Geological history of western Canada: Calgary, Alberta, Alberta Society of Petroleum Geologists, p. 34-42.

Potter, R.W., II, and Brown, D.L., 1977, The volumetric properties of aqueous sodium chloride solutions from $0^{\circ}$ to $500^{\circ} \mathrm{C}$ at pressures up to 2000 bars based on a regression of available data in the literature: U.S. Geological Survey Bulletin 1421-C, 36 p.

Powell, B.F., 1940, Construction history and technical details of Sheridan Dam: Black Hills Engineer, v. 26, p. 180-196.

Powers, R.W., 1962, Arabian Upper Jurassic carbonate reservoir rocks, in Ham, W.E., ed., Classification of carbonate rocks: American Association of Petroleum Geologists Memoir 1, p. 122-192.

Prucha, J.J., Graham, J.A., and Nickelsen, R.P., 1965, Basementcontrolled deformation in Wyoming province of Rocky Mountains foreland: American Association of Petroleum Geologists Bulletin, v. 49 , no. 7 , p. $966-992$.

Purser, B.H., and Evans, G., 1973, Regional sedimentation along the Trucial Coast, SE Persian Gulf, in Purser, B.H., ed., The Persian Gulf: New York, Springer-Verlag, p. 211-231.

Rader, M.T., Jr., 1952, Ordovician and Silurian carbonates of the central Williston basin: Billings Geological Society Annual Field Conference, 3d, 1952, Guidebook, p. 48-55.

Rahn, P.H., and Frazee, C.J., 1974, Drainage alignment in eastern Pennington County, South Dakota: South Dakota Academy of Science Proceedings, v. 53, p. 61-68.

Rahn, P.H., and Gries, J.P., 1973, Large springs in the Black Hills, South Dakota and Wyoming: South Dakota State Geological Survey Report of Investigations 107, 46 p.

Ransome, F.L., 1915, The Tertiary orogeny of the North American Cordillera and its problems, in Problems of American geology: New Haven, Conn., Yale University Press, p. 288-376.

Rascoe, Bailey, Jr., and Baars, D.L., 1972, Permian system, in Geologic atlas of the Rocky Mountain region: Denver, Rocky Mountain Association of Geologists, p. 143-165.

Rayl, R.L., 1956, Stratigraphy of Nesson, Piper, and Rierdon Formations of central Montana: Billings Geological Society Annual Field Conference, 7th, 1956, Guidebook, p. 35-45.

Redden, J.A., 1968, Geology of the Berne quadrangle, Black Hills, South Dakota: U.S. Geological Survey Professional Paper 297-F, p. 343-408.

Redden, J.A., and Norton, J.J., 1975, Precambrian geology of the Black Hills, in Mineral and water resources of South Dakota: U.S. 94th Congress, 1 st session, Senate Committee on Interior and Insular Affairs Report, p. 21-28.

Reeside, J.B., Jr., 1944, Map showing thickness and general character of the Cretaceous deposits in the Western Interior of the United States: U.S. Geological Survey Oil and Gas Investigations Map OM-10, scale 1 inch $=220$ miles.

Rehrig, W.A., and Heidrick, T.L., 1976, Regional tectonic stress during the Laramide and late Tertiary intrusive periods, Basin and Range province, Arizona: Arizona Geological Society Digest, v. 10 , p. 205-228.

Renfro, A.R., ed., 1971, Symposium on Wyoming tectonics and their economic significance guidebook: Casper, Wyo., Wyoming Geological Association, 187 p.
Rice, D.D., 1976, Correlation chart of Cretaceous and Paleocene rocks of the northern Great Plains: U.S. Geological Survey Oil and Gas Investigations Chart OC-70.

1980, Coastal and deltaic sedimentation of Upper Cretaceous Eagle Sandstone-Relation to shallow gas accumulations, northcentral Montana: American Association of Petroleum Geologists Bulletin, v. 64 , no. 3 , p. $316-338$.

Rice, D.D., and Shurr, G.W., 1978, Potential for major natural gas resources in shallow, low-permeability reservoirs of the northern Great Plains: Economic Geology of the Williston Basin, Symposium of the Montana Geological Society, Billings, Mont., 1978, Proceedings, p. 265-281.

1980, Shallow, low-permeability reservoirs of northern Great Plains-Assessment of their natural gas reservoirs: American Association of Petroleum Geologists Bulletin, v. 67, no. 7, p. 969-987.

Richards, P.W., and Nieschmidt, C.L., 1961, The Bighorn Dolomite and correlative formations in southern Montana and northern Wyoming: U.S. Geological Survey Oil and Gas Investigations Map OM-202, scale 1 inch=about 12 miles, 2 sheets.

Riffenburg, H.B., 1926, Chemical character of ground waters of the northern Great Plains, in Contributions to the hydrology of the United States, 1925: U.S. Geological Survey Water-Supply Paper 560-B, p. 31-52.

1976, Mississippian history of the northern Rocky Mountain region: U.S. Geological Survey Journal of Research, v. 4, no. 3, p. 317-338.

Rittenhouse, Gordon, Fulton, R.B., III, Grabowski, R.J., and Bernard, J.L., 1969, Minor elements in oil-field waters, in Geochemistry of subsurface brines: Chemical Geology, v. 4, nos. 1-2, p. 189-209.

Roberts, A.E., 1966, Stratigraphy of Madison Group near Livingston, Montana, and discussion of karst and solution-breccia features: U.S. Geological Survey Professional Paper 526-B, 23 p.

1972, Cretaceous and early Tertiary depositional and tectonic history of the Livingston area, southwestern Montana: U.S. Geological Survey Professional Paper 526-C, 120 p.

1979, Northern Rocky Mountains and adjacent plains region, in Craig, L.C., Connor, C.W., and others, eds., Paleotectonic investigations of the Mississippian system in the United States, Part I-Introduction and regional analyses of the Mississippian system: U.S. Geological Survey Professional Paper 1010, p. 221-248.

Robin, G. de Q., 1955, The movement and temperature distribution on glaciers and ice sheets: Journal of Glaciology, v. 2, p. 523-532.

Robinson, C.S., Mapel, W.J., and Bergendahl, M.H., 1964, Stratigraphy and structure of the northern and western flanks of the Black Hills uplift, Wyoming, Montana, and South Dakota: U.S. Geological Survey Professional Paper 404, 134 p.

Rocky Mountain Association of Geologists, 1972, Geologic atlas of the Rocky Mountain region: Denver, A.B. Hirschfeld Press, 331 p.

Roehl, P.O., 1967, Stony Mountain (Ordovician) and Interlake (Silurian) facies analogs of recent low-energy marine and subaerial carbonates, Bahamas: American Association of Petroleum Geologists Bulletin, v. 51, no. 10, p. 1979-2032.

Rogers, John, 1954, Nature, usage, and nomenclature of stratigraphic units-A minority report: American Association of Petroleum Geologists Bulletin, v. 38 , no. 4 , p. $655-659$.

Rose, P.R., 1976, Mississippian carbonate shelf margins, western United States: U.S. Geological Survey Journal of Research, v. 4, no. 4 , p. $449-466$.

Rösler, H.J., and Lange, Horst, 1972, Geochemical tables: New York, Elsevier, p. 312.

Ross, R.J., Jr., 1957, Ordovician fossils from wells in the Williston basin, eastern Montana: U.S. Geological Survey Bulletin 1021-M, p. $439-510$. 
Rothrock, E.P., 1949, Structures south of the Black Hills: South Dakota State Geological Survey Report of Investigations 62, $52 \mathrm{p}$.

Rothrock, E.P., and Robinson, T.W., Jr., 1936, Artesian conditions in west-central South Dakota: South Dakota State Geological Survey Report of Investigations 26, 93 p.

Rouse, G.E., and Bisque, R.E., 1968, Global tectonics and the Earth's core: Mines Magazine, v. 58, no. 3, p. 28-35.

Routman, C.A., 1978, Sedimentology of Late Jurassic barrier-island complex-lower Sundance Formation of Black Hills: American Association of Petroleum Geologists Bulletin, v. 62, no. 11, p. 2275-2289.

Royse, C.F., Jr., 1967, Tongue River-Sentinel Butte contact in western North Dakota: North Dakota Geological Survey Report of Investigation no. $45,53 \mathrm{p}$.

Royse, C.F., Jr., Warner, M.A., and Reese, D.L., 1975, Thrust belt structural geometry and related stratigraphic problems, Wyoming-Idaho-northern Utah, in Bolyard, D.W., ed., Symposium on Deep Drilling Frontiers of the Central Rocky Mountains, Steamboat Springs, Colo., 1975, Proceedings: Denver, Rocky Mountain Association of Geologists, p. 41-54.

Russell, W.L., 1928, The origin of artesian pressure: Economic Geology, v. 23, no. 2, p. 132-157.

Sales, J.K., 1968, Crustal mechanics of Cordilleran foreland deformation-A regional and scale-model approach: American Association of Petroleum Geologists Bulletin, v. 52, no. 10. p. 2016-2044.

Sandberg, C.A., 1961, Distribution and thickness of Devonian rocks in Williston basin and in central Montana and north-central Wyoming: U.S. Geological Survey Bulletin 1112-D, p. 105-127.

1962, Geology of the Williston basin, North Dakota, Montana, and South Dakota, with reference to subsurface disposal of radioactive wastes: U.S. Geological Survey Open-File Report TEI-809, $148 \mathrm{p}$.

Sandberg, C.A., and Hammond, C.R., 1958, Devonian system in Williston basin and central Montana: American Association of Petroleum Geologists Bulletin, v. 42, no. 10, p. 2293-2334.

Sandberg, C.A., and Mapel, W.J., 1967, Devonian of the northern Rocky Mountains and plains, in Oswald, D.H., ed., International Symposium on the Devonian System, Calgary, Alberta, Canada, 1967, Proceedings, volume 1: Calgary, Alberta, Alberta Society of Petroleum Geologists, p. 843-877.

Sandberg, C.A., and Poole, F.G., 1977, Conodont biostratigraphy and depositional complexes of Upper Devonian cratonic-platform and continental shelf rocks in the western United States, in Murphy, M.A., Berry, W.B.N., and Sandberg, C.A., eds., Western North America-Devonian: University of California at Riverside, Museum Contributions 4, p. 144-182.

Sando, W.J., 1967, Mississippian depositional provinces in the nortlern Cordilleran region, in Geological Survey researcll 1967: U.S. Geological Survey Professional Paper 575-D, p. D29-D38.

1972, Madison Group (Mississippian) and Amsden Formation (Mississippian and Pennsylvanian) in the Beartooth Mountains, northern Wyoming and southern Montana: Montana Geological Society Annual Field Conference, 21st, 1972, Guidebook, p. 57-63.

1974, Ancient solution phenomena in the Madison Limestone (Mississippian) of north-central Wyoming: U.S. Geological Survey Journal of Research, v. 2, no. 2, p. 133-141.

1976a, Madison Limestone, east flank of Bighorn Mountains, Wyoming: Wyoming Geological Association Annual Field Conference, 28th, 1976, Guidebook, p. 45-52.

$1976 \mathrm{~b}$, Mississippian history of the northern Rocky Mountain region: U.S. Geological Survey Journal of Research, v. 4, no. 3, p. $317-338$.

Sando, W.J., and Dutro, J.T., Jr., 1974, Type sections of the Madison
Group (Mississippian) and its subdivisions in Montana: U.S. Geological Survey Professional Paper 842, 22 p.

Sando, W.J., Dutro, J.T., Jr., Sandberg, C.A., and Mamet, B.L., 1976, Revision of Mississippian stratigraphy, eastern Idaho and nortleastern Utah: U.S. Geological Survey Journal of Researclı, v. 4, no. 4 , p. 467-479.

Sando, W.J., Gordon, MacKenzie, Jr., and Dutro, J.T., Jr., 1975 (1976), Stratigraphy and geologic history of the Amsden Formation (Mississippian and Pennsylvanian) of Wyoming: U.S. Geological Survey Professional Paper 848-A, 83 p.

Sando, W.J., Mamet, B.L., and Dutro, J.T., Jr., 1969, Carboniferous megafaunal and microfaunal zonation in the northern Cordillera of the United States: U.S. Geological Survey Professional Paper 613-E, $29 \mathrm{p}$.

Sanford, A.R., 1959, Analytical and experimental study of simple geologic structures: Geological Society of America Bulletin, v. 70, no. 7, p. 19-52.

Santos, E.S., 1981, Facies distribution in uranium host rocks of the southern Powder River basin, Wyoming: U.S. Geological Survey Open-File Report 81-741, 17 p.

Saucier, A.E., 1976, Tectonic influence on uraniferous trends in the Late Jurassic Morrison Formation, in Woodward, L.A., ed., Tectonics and mineral resources of southwestern North America: Albuquerque, N. Mex., University of New Mexico Special Publication no. 6 , p. 151-157.

Schmidt, Volkmar, and McDonald, A., 1979, The role of secondary porosity in the course of sandstone diagenesis, in Scliolle, P.A., ed., Aspects of diagenesis: Society of Economic Paleontologists and Mineralogists Special Publication no. 16, p. 175-207.

Scholle, P.A., 1977, Current oil and gas production from North American Upper Cretaceous chalks: U.S. Geological Survey Circular $767,51 \mathrm{p}$.

1978, A color illustrated guide to carbonate rock constituents, textures, cements, and porosities: American Association of Petroleum Geologists Memoir 27, 241 p.

Schoon, R.A., 1965, Dakota Formation of South Dakota: South Dakota Academy of Science Proceedings, v. 44, p. 72-79.

1971, Geology and hydrology of the Dakota Formation in South Dakota: South Dakota State Geological Survey Report of Investigations $104,55 \mathrm{p}$.

Schultz, L.G., 1964, Quantitative interpretation of mineralogical composition from X-ray and chemical data for the Pierre Shale: U.S. Geological Survey Professional Paper 391-C, 31 p.

1965, Mineralogy and stratigraphy of the lower part of the Pierre Shale, South Dakota and Nebraska: U.S. Geological Survey Professional Paper 392-B, 19 p.

Schultz, L.G., Tourtelot, H.A., Gill, J.R., and Boerngen, J.G., 1980 , Composition and properties of the Pierre Shale and equivalent rocks, northern Great Plains region: U.S. Geological Survey Professional Paper 1064-B, 114 p.

Seager, O.A., 1942, Test on Cedar Creek anticline, soutleastern Montana: American Association of Petroleum Geologists Bulletin, v. 26 , no. 5 , p. $861-864$.

Seeland, D.A., 1976, Relationships between early Tertiary sedimentation patterns and uranium mineralization in the Powder River basin, Wyoming: Wyoming Geological Association Annual Field Conference, 28th, 1976, Guidebook, p. 53-64.

Selley, R.C., 1970, Ancient sedimentary environments: Ithaca, N.Y., Cornell University Press, 237 p.

Sharp, J.C., and Maini, Y.N.T., 1972, Fundamental considerations on the hydraulic characteristics of joints in rock: International Society for Rock Mechanics Symposium on Percolation through Fissured Rock, Stuttgart, West Germany, 1972, Proceedings, Sec. T, p. 1-15.

Shearman, D.J., 1978, Evaporites of coastal subkhas, in Dean, W.E., 
and Schreiber, B.C., eds., Marine evaporites: Society of Economic Paleontologists and Mineralogists Short Course Lecture Notes no. 4 , p. 6-42.

Sheldon, R.P., and Carter, M.D., 1979, Williston basin region, in Craig, L.C., Connor, C.W., and others, eds., Paleotectonic investigations of the Mississippian system in the United States, Part IIntroduction and regional analyses of the Mississippian system: U.S. Geological Survey Professional Paper 1010, p. 249-272.

Shepard, J.H., 1895, The artesian waters of South Dakota: South Dakota Agriculture College and Experiment Station Bulletin 41, $76 \mathrm{p}$.

Shurr, G.W., 1970, Unconformable relationships between the Pierre Shale and Niobrara Formation in central South Dakota: Geological Society of America Abstracts with Programs, v. 2, no. 5, p. 348-349.

1971, Facies relationships between the Pierre Shale and Niobrara Formation in central South Dakota: Geological Society of America Abstracts with Programs, v. 3, no. 4, p. 279.

1977, The Pierre Shale, northern Great Plains-A potential isolation medium for radioactive waste: U.S. Geological Survey Open-File Report 77-776, 27 p.

1978, Landsat lineaments in western South Dakota: U.S. Geological Survey Open-File Report 78-249, 1 plate.

1979, Lineament control of sedimentary facies in the northern Great Plains, U.S., in Podwysocki, M.H., and Earle, J.L., eds., International Conference on New Basement Tectonics, 2d, Newark, Del., 1976, Proceedings: Denver, Basement Tectonics Committee, Inc., p. 413-422.

Siedlecka, Anna, 1972, Length-slow chalcedony and relicts of sulphates-Evidences of evaporitic environments in the upper Carboniferous and Permian beds of Bear Island, Svalbard: Journal of Sedimentary Petrology, v. 42, no. 2, p. 812-816.

Skougstad, M.W., Fishman, M.J., Friedman, L.C., Erdmann, D.E., and Duncan, S.S., eds., 1978, Methods for determination of analysis of inorganic substances in water and fluvial sediments: U.S. Geological Survey Techniques of Water-Resources Investigations, bk. 5, chap. A1, 626 p.

Slack, P.B., 1981, Paleotectonics and hydrocarbon accumulation, Powder River basin, Wyoming: American Association of Petroleum Geologists Bulletin, v. 65, no. 4, p. 730-743.

Sloss, L.L., 1950, Paleozoic sedimentation in Montana area: American Association of Petroleum Geologists Bulletin, v. 34, no. 3, p. 423-451.

1969, Evaporite deposition from layered solutions: American Association of Petroleum Geologists Bulletin, v. 53, no. 4, p. 776-789.

Sloss, L.L., Dapples, E.C., and Krumbein, W.C., 1960, Lithofacies maps-An atlas of the United States and southern Canada: New York, John Wiley, 108 p.

Sloss, L.L., and Speed, R.C., 1974, Relationships of cratonic and continental-margin tectonic episodes, in Tectonics and sedimentation: Society of Economic Paleontologists and Mineralogists Special Publication 22, p. 98-119.

Smith, D.L., 1972, Depositional cycles of the Lodgepole Formation (Mississippian) in central Montana: Montana Geological Society Annual Field Conference, 21st, 1972, Guidebook, p. 27-36.

Smith, D.L., and Gilmour, E.H., 1979, The Mississippian and Pennsylvanian (Carboniferous) systems in the United States-Montana: U.S. Geological Survey Professional Paper 1110-X, p. X1-X32.

Smith, J.G., 1965, Fundamental transcurrent faulting in northern Rocky Mountains: American Association of Petroleum Geologists Bulletin, v. 49, no. 9, p. 1398-1409.

Snow, D.T., 1968, Rock fracture spacings, openings, and porosities: Proceedings of the American Society of Civil Engineers, Journal of the Soil Mechanics and Foundations Division, v. 94, no. SM1, p. 73-91.
1970, The frequency and apertures of fractures in rock: International Journal of Rock Mechanics and Mining Sciences, v. 7 , no. 1, p. $23-40$.

Sonder, R.A., 1947, Discussion of shear patterns of the earth's crust by F.A. Vening-Meinesz: Transactions of the American Geophysical Union, v. 28, no. 6, p. 939-945.

Sonnenberg, F.P., 1956, Tectonic patterns of central Montana: Billings Geological Society Annual Field Conference, 7th, 1956, Guidebook, p. 73-81.

Spivey, R.S., 1940, Bentonite in southwestern South Dakota: South Dakota State Geological Survey Report of Investigations 36, 56 p.

Stanton, R.J., Jr., 1966, The solution brecciation process: Geological Society of America Bulletin, v. 77, no. 8, p. 843-847.

Stapp, R.W., 1967, Relationship of Lower Cretaceous depositional environments to oil accumulation, northeastern Powder River basin, Wyoming: American Association of Petroleum Geologists Bulletin, v. 51 , no. 10 , p. $2044-2055$.

Statistical Analysis System Institute Staff, 1979, SAS user's guide: Raleigh, N.C., SAS Institute, Inc., 494 p.

Stearns, D.W., 1971, Mechanisms of drape folding in the Wyoming province: Wyoming Geological Association Annual Field Conference, 23d, 1971, Guidebook, p. 125-143.

Stearns, D.W., and Jamison, W.R., 1977, Deformation of sandstones over basement uplifts, Colorado National Monument, in Veal, H.K., ed., Exploration Frontiers of the Central and Southern Rockies Symposium, Aspen, Colo., 1977, Proceedings: Denver, Rocky Mountain Association of Geologists, p. 31-39.

Stearns, D.W., Sacrison, W.R., and Hanson, R.C., 1975, Structural history of southwestern Wyoming as evidenced from outcrop and seismic, in Bolyard, D.W., ed., Symposium on Deep Drilling Frontiers in the Central Rocky Mountains, Steamboat Springs, Colo., 1975, Proceedings: Denver, Rocky Mountain Association of Geologists, p. 9-20.

Steece, F.V., 1961, Preliminary map of the Precambrian surface of South Dakota: South Dakota State Geological Survey Mineral Resources Investigations Map 2, scale 1 inch $=17$ miles.

1975, Structural geology outside of the Black Hills, in Mineral and water resources of South Dakota: U.S. 94th Congress, 1st session, Committee on Interior and Insular Affairs Report, p. 50-53.

1978, Deadwood Formation in the Williston basin: Montana Geological Society Annual Conference, 24th (Williston Basin Symposium), Billings, Mont., 1978, Guidebook, p. 63-69.

Steece, F.V., and Howells, L.W., 1965, Geology and ground water supplies in Sanborn County, South Dakota: South Dakota State Geological Survey Bulletin 17, 182 p.

Steel, R.J., Maehle, S., Nilsen, H., Roe, S.L., and Spinnangr, A., 1977, Coarsening-upward cycles in the alluvium of Hornelen Basin (Devonian), Norway-Sedimentary response to tectonic events: Geological Society of America Bulletin, v. 88, no. 8, p. 1124-1134.

Stenzel, Sheila, Buss, Rebecca, and Busby, J.F., 1980, Maps showing dissolved-solids concentration of waters in the Red River Formation and Mission Canyon Limestone in North Dakota, South Dakota, and parts of Wyoming and Montana: U.S. Geological Survey Open-File Report 80-748, scale 1:1,000,000, 2 sheets.

Stone, D.S., 1969, Wrench faulting and Rocky Mountain tectonics: Wyoming Geological Association Earth Science Bulletin, v. 2, no. 2 , p. $27-41$.

1970, Principal horizontal stress in the central Rocky Mountains versus California: The Mountain Geologist, v. 7, no. 2, p. $69-82$.

1971, Tectonic sketch map of the central Rocky Mountains: Wyoming Geological Association Annual Field Conference, 23d, 1971 , Guidebook, scale 1 inch $=30$ miles.

1974, Lineaments: Their role in tectonics of central Rocky 
Mountains-A discussion: Wyoming Geological Association Earth Science Bulletin, v. 7, no. 4, p. 1-11.

Stone, D.S., and Hoeger, R.L., 1973, Importance of hydrodynamics factors in formation of Lower Cretaceous combination traps, Big Muddy-south Glenrock area, Wyoming: American Association of Petroleum Geologists Bulletin, v. 57, no. 9, p. 1714-1733.

Stone, H.K., 1968, Iterative solution of implicit approximations of multi-dimensional partial differential equations: Society for Industrial and Applied Mathematics Journal of Numerical Analysis, v. 5 , no. 3 , p. $530-558$.

Stone, R.A., 1972, Waulsortian-type bioherms (reefs) of Mississippian age, central Bridger Range, Montana: Montana Geological Society Annual Field Conference, 21st, 1972, Guidebook, p. 37-56.

Stone, W.D., 1971, Stratigraphy and exploration of the Lower Cretaceous Muddy Formation northern Powder River basin, Wyoming and Montana: The Mountain Geologist, v. 9, no. 4, p. 355-378.

Stoner, J.D., and Lewis, B.D., 1980, Hydrogeology of the Fort Union coal region, eastern Montana: U.S. Geological Survey Miscellaneous Investigations Series Map I-1236, scale 1:500,000, 2 sheets.

Streltsova, T.D., 1976, Hydrodynamics of ground water flow in a fractured formation: Water Resources Research, v. 12, no. 3, p. 405-414.

Strickland, J.W., 1958, Habitat of oil in the Powder River basin: Wyoming Geological Association Annual Field Conference, 13th, 1958, Guidebook, p. 132-147.

Stumm, Werner, and Morgan, J.J., 1981, Aquatic chemistry (2d ed.): New York, Wiley Interscience, 780 p.

Swenson, F.A., 1968a, New theory of recharge in the artesian basin of the Dakotas: Geological Society of America Bulletin, v. 79, no. 1 , p. $163-182$.

$1968 \mathrm{~b}$, Recharge and movement of water in the artesian basin of the Dakotas in Black Hills area, South Dakota, Montana, Wyoming: Wyoming Geological Association Annual Field Conference, 10th, 1968, Guidebook, p. 199-207.

1974, Possible development of water from Madison Group and associated rocks in Powder River basin, Montana-Wyoming: Northern Great Plains Resources Program, $6 \mathrm{p}$.

Swenson, F.A., Miller, W.R., Hodson, W.G., and Visher, F.N., 1975, Water in the Madison Group, Powder River basin, Wyoming and Montana: U.S. Geological Survey Open-File Report 75-660, 29 p. 1976, Map showing the configuration and thickness and potentiometric surface and water quality in the Madison Group, Powder River basin, Wyoming and Montana: U.S. Geological Survey Miscellaneous Investigations Series Map I-847-C, scale $1: 1,000,000,2$ sheets.

Taylor, O.J., 1978, Summary appraisals of the Nation's ground-water resources-Missouri Basin region: U.S. Geological Survey Professional Paper 813-Q, $41 \mathrm{p}$.

Tenney, C.S., 1966, Pennsylvanian and Lower Permian deposition in Wyoming and adjacent areas: American Association of Petroleum Geologists Bulletin, v. 50, no. 2, p. 227-250.

Thatcher, L.L., Janzer, V.J., and Edwards, R.W., 1977, Methods for determination of radioactive substances in water and fluvial sediments: U.S. Geological Survey Techniques of Water-Resources Investigations, bk. 5, chap. A5, 95 p.

Thayer, P.A., 1981, Petrology and petrography for U.S. Geological Survey test wells 1,2 , and 3 in the Madison Limestone in Montana and Wyoming: U.S. Geological Survey Open-File Report 81-221, $94 \mathrm{p}$.

Thayer, P.A., and Textoris, D.A., 1977, Faunal and diagenetic controls of porosity and permeability in Tertiary aquifer carbonates, North Carolina: North Carolina Department of Natural Resources and Community Development, Division of Earth Resources Special Publication 7, 35 p.
Theodosis, S.D., 1955, Belt series of northwestern Montana: Billings Geological Society Annual Field Conference, 6th, 1955, Guidebook, p. 58-63.

Thom, W.T., Jr., 1923, The relation of deep-seated faults to the surface structural features of central Montana: American Association of Petroleum Geologists Bulletin, v. 7, no. 1, p. 1-13.

Thom, W.T., Jr., Hall, G.M., Wegemann, C.H., and Moulton, G.F., 1935, Geology of Big Horn County and the Crow Indian Reservation, Montana, with special reference to the water, coal, oil, and gas resources: U.S. Geological Survey Bulletin 856, 200 p.

Thomas, G.E., 1971, Continental plate tectonics, southwest Wyoming, in Renfro, A.R., ed., Symposium on Wyoming Tectonics and Their Economic Significance, Casper, Wyo., 1971, Guidebook: Casper, Wyo., Wyoming Geological Association, p. 103-123.

1974, Lineament-block tectonics-Williston-Blood Creek basin: American Association of Petroleum Geologists Bulletin, v. 58, no. 7, p. 1305-1322.

1976, Lineament-block tectonics-North American-Cordilleran orogen, in Podwysocki, M.H., and Earle, J.L., eds., International Conference on New Basement Tectonics, 2d, Newark, Del., 1976, Proceedings: Denver, Basement Tectonics Committee, Inc., p. 361-370.

Thomas, H.D., 1962, Some problems of the earlier Cretaceous rocks of Wyoming: Wyoming Geological Association Annual Field Conference, 17th, 1962, Guidebook, p. 28-32.

Thorstenson, D.C., Fisher, D.W., and Croft, M.G., 1979, The geochemistry of the Fox Hills-Basal Hell Creek aquifer in southwestern North Dakota and northwestern South Dakota: Water Resources Research, v. 15, no. 7, p. 1479-1498.

Till, Roger, 1978, Arid shorelines and evaporites, in Reading, H.G., ed., Sedimentary environments and facies: New York, Elsevier, p. 178-206.

Todd, J.E., and Hall, C.M., 1904, Geology and water resources of part of the lower James River valley, South Dakota: U.S. Geological Survey Water-Supply Paper 90, 47 p.

Tourtelot, H.A., 1962, Preliminary investigation of the geologic setting and chemical composition of the Pierre Shale, Great Plains region: U.S. Geological Survey Professional Paper 390, 74 p.

Tourtelot, H.A., and Brenner-Tourtelot, E.F., 1977, Lithium in flint clays, bauxite, related high-alumina materials and sedimentary rocks in the United States-A preliminary study: U.S. Geological Survey Open-File Report 77-786, 46 p.

Towse, D.F., 1952, Subsurface geology of south-central North Dakota: North Dakota Academy of Science Proceedings, v. 6, p. 26-34.

Toy, T.J., and Munson, B.E., 1978, Climate appraisal maps of the rehabilitation potential of strippable coal lands in the Powder River basin, Wyoming and Montana: U.S. Geological Survey Miscellaneous Field Studies Map MF-932, scale 1:1,000,000, 2 sheets.

Trescott, P.C., 1975, Documentation of finite-difference model for simulation of three dimensional ground-water flow: U.S. Geological Survey Open-File Report 75-438, 30 p. plus appendix.

Trescott, P.C., and Larson, S.P., 1976, Supplement to U.S. Geological Survey Open-File Report 75-438, documentation of finitedifference model for simulation of three-dimensional ground-water flow: U.S. Geological Survey Open-File Report 76-591, 17 p.

Trimble, D.E., 1980, The geologic story of the Great Plains: U.S. Geological Survey Bulletin 1493, 55 p.

Truesdell, A.H., and Jones, B.F., 1974, WATEQ-A computer program for calculating chemical equilibria of natural waters: U.S. Geological Survey Journal of Research, v. 2, no. 2, p. 233-274.

Tweto, Ogden, 1975, Laramide (Late Cretaceous-early Tertiary) orogeny in the southern Rocky Mountains, in Curtis, B.F., ed., Cenozoic history of the southern Rocky Mountains: Geological Society of America Memoir 144, p. 1-44. 
U.S. Bureau of Reclamation, 1972, Report on resources of eastern Montana basins, Pick-Sloan Missouri basin program, Montana: $91 \mathrm{p}$.

U.S. Geological Survey, 1975, Plan of study of the hydrology of the Madison Limestone and associated rocks in parts of Montana, Nebraska, North Dakota, South Dakota, and Wyoming: U.S. Geological Survey Open-File Report 75-631, 44 p.

Vail, P.R., Mitchum, R.M., Jr., and Thompson, S., III, 1977, Seismic stratigraphy and global changes of sea level, part 4, in Seismic stratigraphy-Applications to hydrocarbon exploration: American Association of Petroleum Geologists Memoir 26, p. 83-97.

van Everdingen, R.O., 1968, Studies of formation waters in western Canada-Geochemistry and hydrodynamics: Canadian Journal of Earth Sciences, v. 5, no. 3, p. 523-543.

van Hees, Hendrik, and North, F.K., 1964, Cambrian, in Geological history of western Canada: Calgary, Alberta, Alberta Society of Petroleum Geologists, p. 20-33.

Van Hinte, J.E., 1976a, A Cretaceous time scale: American Association of Petroleum Geologists Bulletin, v. 60, no. 4, p. 498-516. 1976b, A Jurassic time scale: American Association of Petroleum Geologists Bulletin, v. 60, no. 4, p. 489-497.

Vening-Meinesz, F.A., 1947, Shear patterns of the earth's crust: Transactions of the American Geophysical Union, v. 28, no. 1, p. 1-61.

Vine, J.D., 1975a, Origin of lithium in sedimentary rocks and brines: U.S. Geological Survey Journal of Research, v. 3, no. 1, p. 42. 1975b, Lithium in sediments and brines-How, why, and where to search: U.S. Geological Survey Journal of Research, v. 3, no. 4 , p. $479-483$.

Vlissides, S.D., and Quirin, B.A., 1964, Oil and gas fields of the United States, exclusive of Alaska and Hawaii: U.S. Geological Survey, scale $1: 2,500,000,2$ sheets.

Waage, K.M., 1959, Stratigraphy of the Inyan Kara Group in the Black Hills: U.S. Geological Survey Bulletin 1081-B, p. 11-90.

Wallace, R.H., Jr., Kraemer, T.F., Taylor, R.E., and Wesselman, J.B., 1979, Assessment of geopressured-geothermal resources in the northern Gulf of Mexico basin, in Muffler, L.J.P., ed., Assessment of geothermal resources of the United States-1978: U.S. Geological Survey Circular 790, p. 132-165.

Walton, W.C., 1962, Selected analytical methods for well and aquifer evaluation: Illinois State Water Survey Bulletin 49, 81 p.

Wardlaw, N.C., 1979, Pore systems in carbonate rocks and their influence on hydrocarbon recovery efficiency, in Geology of carbonate porosity: American Association of Petroleum Geologists Continuing Education Course Note Series 11, 24 p.

Waring, Juliana, 1975, Depositional environments of the Lower Cretaceous Muddy Sandstone, southeastern Montana: College Station, Tex., Texas A \& M University Ph. D. dissertation, 195 p.

Warner, L.A., 1978, The Colorado lineament-A middle Precambrian wrench fault system: Geological Society of America Bulletin, v. 89 , no. 2 , p. $161-171$.

1980, The Colorado lineament, Denver, Rocky Mountain Association of Geologists, in Rocky Mountain Association of Geologists Guidebook, p. 11-21.

Weertman, Johannes, 1972, General theory of water flow at the base of a glacier or ice sheet: Reviews of Geophysics and Space Physics, v. 10 , no. 1 , p. $287-333$

Weimer, R.J., 1960, Upper Cretaceous stratigraphy, Rocky Mountain area: American Association of Petroleum Geologists Bulletin, v. 44 , no. 1,20 p.

1962, Late Jurassic and Early Cretaceous correlations, southcentral Wyoming and northwestern Colorado: Wyoming Geological Association Annual Field Conference, 17th, 1962, Guidebook, p. 124-129.

1976, Deltaic and shallow marine sandstones-Sedimentation, tectonics and petroleum occurrences: American Association of
Petroleum Geologists Continuing Education Course Note Series 2, $167 \mathrm{p}$.

1978, Influence of Transcontinental arch on Cretaceous marine sedimentation-A preliminary report, in Energy resources of the Denver basin: Denver, Rocky Mountain Association of Geologists, p. 211-222.

1980, Recurrent movement on basement faults, a tectonic style for Colorado and adjacent areas, in Colorado geology: Denver, Rocky Mountain Association of Geologists, p. 23-35.

Weimer, R.J., Emme, J.J., Farmer, C.L., and Anna, L.O., Davis, T.L., and Kidney, R.L., 1982, Tectonic influences of sedimentation, Early Cretaceous, east flank Powder River basin, Wyoming and South Dakota: Colorado School of Mines Quarterly, v. 77, no. 4, $61 \mathrm{p}$.

Weimer, R.J., and Haun, J.D., 1960, Cretaceous stratigraphy, Rocky Mountain region, U.S.A., in Regional paleogeography: International Geological Congress, 21st, Copenhagen, 1960, Proceedings, Part XII, p. 178-184.

Weimer, R.J., and Land, C.B., 1975, Maestrichtian deltaic and interdeltaic sedimentation in the Rocky Mountain region of the United States, in Caldwell, W.G.E., ed., Cretaceous system in the Western Interior of North America: Geological Association of Canada Special Paper 13, p. 633-666.

Weiss, Emanuel, 1982a, A model for the simulation of flow of variabledensity ground water in three dimensions under steady-state conditions: U.S. Geological Survey Open-File Report 82-352, 70 p.

$1982 \mathrm{~b}$, A computer program for calculating relativetransmissivity input arrays to aid model calibration: U.S. Geological Survey Open-File Report 82-447, 22 p.

Weller, J.M., and others, 1948, Correlation of the Mississippian formations of North America: Geological Society of America Bulletin, v. 59 , no. 2 , p. $91-196$.

Weyl, P.K., 1960, Porosity through dolomitization-Conservation-ofmass requirements: Journal of Sedimentary Petrology, v. 30, no. 1, p. 85-90.

Whitcomb, H.A., Morris, D.A., Gordon, E.D., and Robinove, C.J., 1958, Occurrence of ground water in the eastern Powder River basin and western Black Hills, northeastern Wyoming: Wyoming Geological Association Annual Field Conference, 13th, 1958, Guidebook, p. 245-260.

White, D.E., 1965, Saline waters of sedimentary rocks, in Young, Addison, and Galley, J.E., eds., Fluids in subsurface environment: American Association of Petroleum Geologists Memoir 4, p. $342-366$.

White, D.E., Hem, J.D., and Waring, G.A., 1963, Chemical composition of subsurface waters: U.S. Geological Survey Professional Paper 440-F, p. F1-F67.

Wigley, T.M.L., Plummer, L.N., and Pearson, F.J., Jr., 1978, Mass transfer and carbon isotope evolution in natural water systems: Geochimica et Cosmochimica Acta, v. 42, no. 8, p. 1117-1140.

Wilcox, R.E., Harding, T.P., and Seeley, D.R., 1973, Basic wrench tectonics: American Association of Petroleum Geologists Bulletin, v. 57 , no. 1 , p. $74-96$.

Willis, R.P., 1959, Upper Mississippian-Lower Pennsylvanian stratigraphy of central Montana and Williston basin (North Dakota): American Association of Petroleum Geologists Bulletin, v. 43, no. 8, p. $1940-1966$.

Wilson, J.L., 1955, Devonian correlations in northwestern Montana: Billings Geological Society Annual Field Conference, 6th, 1955, Guidebook, p. 70-77.

1967, Carbonate-evaporite cycles in lower Duperow Formation of Williston basin: Bulletin of Canadian Petroleum Geology, v. 15 , no. 3 , p. $230-312$.

1969 , Microfacies and sedimentary structures in "deeper water" lime mudstones, in Depositional environments in carbonate rocks: 
Society of Economic Paleontologists and Mineralogists Special Publication 14, p. 4-19.

1975, Carbonate facies in geologic history: New York, SpringerVerlag, $471 \mathrm{p}$.

Wilson, P.C., 1962, Pennsylvanian stratigraphy of Powder River basin, in Pennsylvanian system in the United States: Tulsa, Okla., American Association of Petroleum Geologists, p. 117-158.

Wing, M.E., 1938, A structural survey of the Pierre gas field, South Dakota: South Dakota State Geological Survey Report of Investigations $29,20 \mathrm{p}$.

Witherspoon, P.A., Amick, C.H., Gale, J.E., and Iwai, Katsuhiko, 1979 , Observations of a potential size effect in experimental determination of the hydraulic properties of fractures: Water Resources Research, v. 15, no. 5, p. 1142-1146.

Woessner, W.W., Osborne, T.J., Heffern, E.L., Andrews, Charles, Whiteman, Jason, Spotted Elk, Wesley, and Morales-Brink, Daniel, 1981, Hydrologic impacts from potential coal strip mining, Northern Cheyenne Reservation: U.S. Environmental Protection Agency, Northern Cheyenne Research Project, Report no. EPA-600/S7-81-004, 303 p.

Wood, W.W., 1976, Guidelines for collection and field analysis of ground-water samples for selected unstable constituents: U.S. Geological Survey Techniques of Water-Resources Investigations, bk. 1 , chap. D2, 24 p.
Woodward, L.A., 1976, Laramide deformation of Rocky Mountain foreland- Geometry and mechanics, in Woodward, L.A., ed., Tectonics and mineral resources of southwestern North America: Albuquerque, N. Mex., University of New Mexico Special Publication 6, p. 11-17.

Woolsey, L.H., Richards, R.W., and Lupton, C.T., 1917, The Bull Mountains coal field, Musselshell and Yellowstone Counties, Montana: U.S. Geological Survey Bulletin 647, 218 p.

Wulf, G.R., 1962, Lower Cretaceous Albian rocks in northern Great Plains: American Association of Petroleum Geologists Bulletin, v. 46, no. 8, p. 1371-1415.

Wyoming Geological Association (Technical Studies Committee), 1965, Geologic history of Powder River basin: American Association of Petroleum Geologists Bulletin, v. 49, no. 11, p. 1893-1907.

Wyoming State Engineer's Office, 1974, Underground water supply in the Madison Limestone: Cheyenne, Wyo., $117 \mathrm{p}$.

1976. Investigation of recharge to groundwater reservoirs of northeastern Wyoming (the Powder River basin): Washington, D.C., Old West Regional Commission, 111 p.

Zimmerman, E.A., 1964, Geology and water resources of the Bluewater Springs area, Carbon County, Montana: U.S. Geological Survey Water-Supply Paper 1779-J, p. J1-J24.

1966, Geology and ground-water resources of western and southern parts of Judith Basin, Montana: Montana Bureau of Mines and Geology Bulletin 50-A, 33 p. 